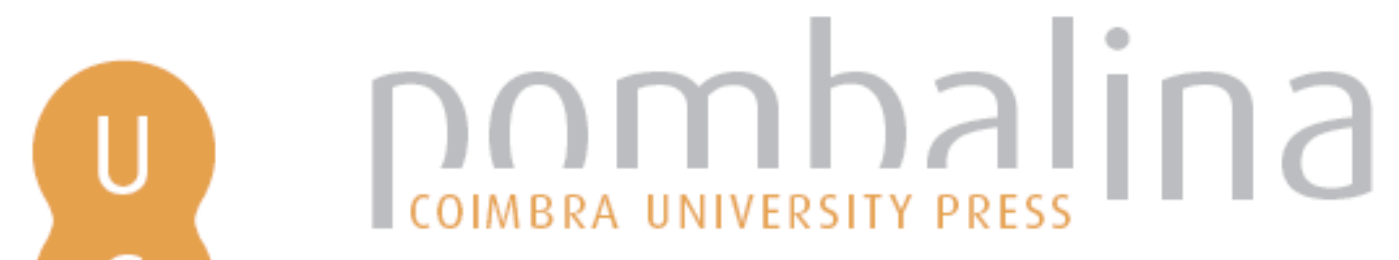

\title{
Greek vases in Portugal
}

Autor(es): $\quad$ Pereira, Maria Helena da Rocha

Publicado por: Centro de Estudos Clássicos e Humanísticos

URL

persistente: URI:http://hdl.handle.net/10316.2/2354

DOI: $\quad$ DOI:http://dx.doi.org/10.14195/978-989-8281-25-8

Accessed : $\quad$ 26-Apr-2023 14:56:51

A navegação consulta e descarregamento dos títulos inseridos nas Bibliotecas Digitais UC Digitalis, UC Pombalina e UC Impactum, pressupõem a aceitação plena e sem reservas dos Termos e Condições de Uso destas Bibliotecas Digitais, disponíveis em https://digitalis.uc.pt/pt-pt/termos.

Conforme exposto nos referidos Termos e Condições de Uso, o descarregamento de títulos de acesso restrito requer uma licença válida de autorização devendo o utilizador aceder ao(s) documento(s) a partir de um endereço de IP da instituição detentora da supramencionada licença.

Ao utilizador é apenas permitido o descarregamento para uso pessoal, pelo que o emprego do(s) título(s) descarregado(s) para outro fim, designadamente comercial, carece de autorização do respetivo autor ou editor da obra.

Na medida em que todas as obras da UC Digitalis se encontram protegidas pelo Código do Direito de Autor e Direitos Conexos e demais legislação aplicável, toda a cópia, parcial ou total, deste documento, nos casos em que é legalmente admitida, deverá conter ou fazer-se acompanhar por este aviso.

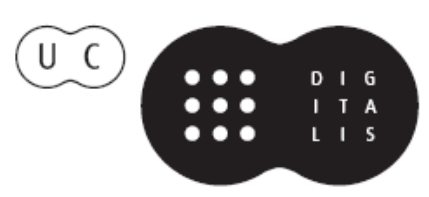




\section{HELENA DA ROCHA PEREIRA}

\section{GR E E K V A S E S \\ I N P O R T U G A L}

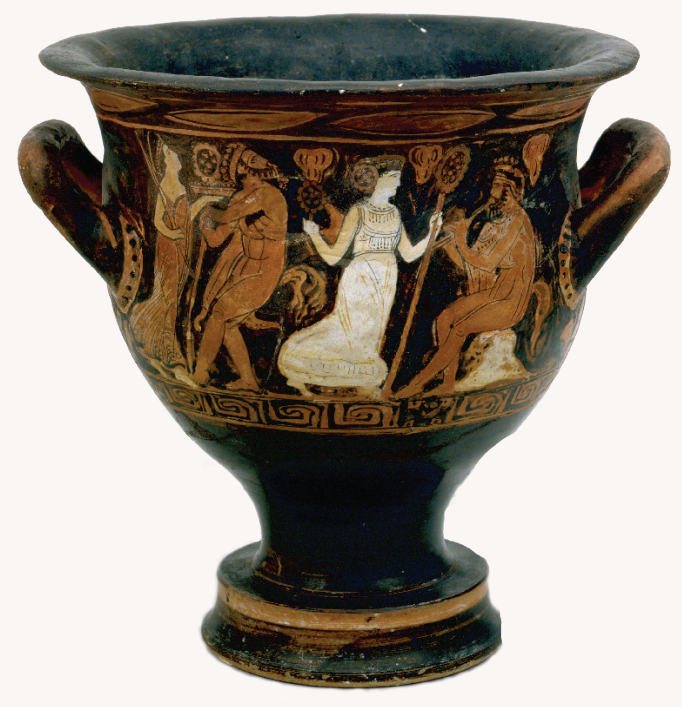


GREEK VASES

IN PORTUGAL 


\section{G R E E K VA S E S I N P O R T U G A L}

B Y

M. HELENA ROCHA PEREIRA

COIMBRA

2010 
AutHOR

Maria Helena da Rocha Pereira

TitLE

Greek Vases in Portugal

PuBlisher

Centro de Estudos Clássicos e Humanísticos da Universidade de Coimbra

EDITION

2nd./2010 (1st. edition in 1962)

Academic Co-ordinator of the Editorial Plan

Maria do Céu Fialho

EDITORIAL BOARD

José Ribeiro Ferreira, Maria de Fátima Silva, Francisco de Oliveira, Nair de Castro Soares

Technical Director of the Collection

Delfim F. Leão

DESIGNER

Rodolfo Lopes

ISBN: 978-989-8281-24-1

DigitaL ISBN: 978-989-8281-25-8

Legal Deposit: 308813/10

(C) Centro de Estudos Clássicos e Humanísticos da Universidade de Coimbra

(C) Classica Digitalia Vniversitatis Conimbrigensis

All rights reserved. No part of this publication may be reproduced, stored in a retrieval system, or transmitted, in any form or by any means, electronic, photocopying, or otherwise, without the written permission of the publisher. 


\section{FOREWORD}

The aim of this book is to give an accurate and, as complete as possible, account of Greek Vases in Portugal. It has been known for many years that a few specimens of Hellenic pottery had turned up in this country, and that a few others came here by acquisition, but most of them remained unpublished or even unknown, and others were lost trace of.

In 1950-1951, during my first sojourn as a recognized student in the University of Oxford, I was lucky enough to attend Prof. Sir John Beazley's lectures on Greek Vases. Anybody who has been granted this priviledge knows how stimulating contact with this most famous scholar can be. I will, therefore, only state a few facts which may be of interest to readers of this book: when I went to Oxford again, in the Michaelmas Term, 1954, I had already collected most of the material for my first paper on the subject (afterwards published in Humanitas VII-VIII); then 
in March and April 1959, after I had gained access to other collections, I worked under Prof. Beazley's supervision. This part of my studies appeared soon afterwards in Humanitas XI-XII and Archivo Español de Arqueología XXXI. A few months later I encountered new material, which I discussed in a paper included in Conimbriga I. I then resolved to collect all the papers in a single volume which would contain a study of the vases in chronological order, and not, as formerly, according to their whereabouts. This is, therefore, what the reader will find here, together with two further vases and a fragment, which are now published for the first time.

It is my pleasant task to acknowledge help of various kinds towards the completion of this book. Nobody who reads it will need to be told how much the author owes to Prof. Beazley's generous advice, though any blemishes that may have been left are 
certainly not his. I am also indebted to Prof. A. D. Trendall, of Canberra University, Australia, for some valuable suggestions; to Prof. B. Ashmole, of Oxford University, for a photograph; to Dr. Dietrich von Bothmer, of the Metropolitan Museum in New York, for indicating a reference; and to Mr. J. M. Bairrão Oleiro, of Coimbra University, for some bibliographical references and for introducing me to new material.

I also wish to express my grateful thanks to the owners of the vases: to the Prime Minister, Prof. A. Oliveira Salazar, and the Duke of Palmella, Mr. Alvaro de Brée, Prof. F. Gentil, Mr. Leland H. Gilbert, Mr. Eduardo Malta, Dr. Henrique Moutinho and Mr. Manuel Vinhas, all of Lisbon, for their kind permission to photograph and study them; to Prof. Manuel Heleno, Director of the Lisbon Ethnological Museum, to Dr. António Luís Gomes, Director of the Palace of Vila Viçosa (Évora), and 
to Dr. H. A. Perdigão, President of the Gulbenkian Foundation, for having been granted access to the vases under their care; and last but not least, to Prof. J. Providencia e Costa, the Dean of the Faculty of Arts of Coimbra, for the interest taken in this work and for including it in the publications of the Faculty.

I also wish to thank Miss Kay G. Keighley for reading and revising my English manuscript.

M. HELENA ROCHA PEREIRA

Coimbra, May 1962 
The first edition of this book has been out of print for many years, and, as it happens, the whereabouts of some of the vases described here are no longer known. Nevertheless, it is a pleasure to state that a few more specimens, which have been discussed elsewhere, have been added to the collection of the National Archaeological Museum in Lisbon (formerly called Portuguese Ethnological Museum), among them a Panathenaic Amphora from the Palmella Collection. Meanwhile, some very small collections, like the one at Coimbra University and the one in Vila Viçosa Palace, Évora, have been preserved.

A special case is the Attic black-figured Hydria ( ${ }^{\circ} 9$ in this book), which already had an adventurous story behind it and has been cleaned in 1964 by the most expert hands one could wish for, Dr. Dietrich von Bothmer himself. The results of this operation, which I published recently under the title "Greek Vases in Portugal. A new Supplement"1 are given at the end of the present book.

\footnotetext{
${ }^{1}$ Humanitas LX (2008) 3-10.
} 
On the whole, although this is hardly more than a reprint of the 1962 edition, I hope it will be of some use to those who understand the value of Greek vases.

My thanks are due to the National Archaeological Museum, to the Gulbenkian Museum and to the Institue of Archaeology - University of Coimbra for permission to publish many photographs from the catalogue of the exhibition "Vasos Gregos em Portugal. Aquém das Colunas de Hércules" (Lisbon 2007); and to Mr. J. P. Moreira, M. A., for reading and revising the English manuscript of the above mentioned Supplement, and to Prof. Delfim Leão and Mr. R. Lopes, M. A., for seeing the whole book through the press.

Coimbra, March 2010

M. H. R. P. 


\section{CONTENTS}

FOREWORD

Page

List OF PLATES

$\mathbf{v}$

Abbreviations

xiii

INTRODUCTION

xvii

1. Vases found at Alcácer do Sal

1

2. Vases acquired abroad

Mycenaean

1. One-handled cup 23

$\begin{array}{lr}\text { GeOMETRIC } & 25\end{array}$

2. Geometric jug 27

Corinthian $\quad 29$

3.4. Alabastra 31

5. Alabastron 31

$\begin{array}{ll}\text { CYPRIOT } & 33\end{array}$

6. Barrel-jug $\quad 35$

$\begin{array}{ll}\text { ATtIC BLACK-FIGURE } & 37\end{array}$

7. Band-cup 39

8. Cup 39

9. Hydria 4

10. Panathenaic amphora 47

11. Fat lekythos 48

12. Lekythos 49

13.14. Lekythoi 44

15. Lekythos 50

16. Lekythos $\quad 50$

17. Lekythos $\quad 51$

ATtIC White LEKYTHOI $\quad 53$

18. White lekythos $\quad 55$

19. White lekythos $\quad 55$

20. White lekythos $\quad 56$

21. White lekythos $\quad 56$

$\begin{array}{ll}\text { AtTiC RED-Figure } & 57\end{array}$

22. Fragment of a column-krater 59 
23. Nolan amphora

24. Nolan amphora

25. Column-krater

26. Calyx-krater

27. Squat lekythos

28. Bell-krater

29. Bell-krater

30. Pelike

31. Skyphos

32. Skyphos

Attic plain black

33. Cup

34. Cup-skyphos

35. Squat lekythos

36. Squat lekythos

37. Squat lekythos

38. Oinochoe

ITALIOTE

39. Squat lekythos 93

40. Lebes gamikos $\quad 93$

41. Fish plate $\quad 95$

Apulian

\begin{tabular}{lr} 
42. & Pelike \\
\hline
\end{tabular}

$\begin{array}{ll}\text { Paestan } & 101\end{array}$

43. Hydria 103

$\begin{array}{ll}\text { Campanian } & 117\end{array}$

44. Calyx-krater 119

45. Bell-krater 121

$\begin{array}{ll}\text { Cumaean } & 131\end{array}$

46. Small amphora 133

Hellenistic $\quad 135$

47.48. Small amphorae 137

49. Lacrimatorium 137

Roman 139

50. Lacrimatorium 141

$\begin{array}{ll}\text { BibliogRAPHY } & 143\end{array}$

INDEX I - Ancient authors quoted $\quad 151$

INDEX II - Modern Authorities $\quad 153$

INDEX III - Painters, Groups $\quad 155$

Greek Vases in Portugal. A New Supplement 169 


\section{LIST OF PLATES}

AT END OF BOOK

(THE NUMBERS IN BRACKETS REFER TO THE TEXT)

I. 1,2

II

III. 1

III. 2

III. 3

IV

V-VI

VII-IX

X-XI

X-A-XI-B

XII-XIII

XIV

XV. 1,2

XVI. 1-3
MYCENAEAN ONE-HANDLED CUP (1)

Photo: Mário Novais, Lisbon / VGP 2007.

GeOMETRIC JUG (2)

Photo by the author.

Corinthian alabastron (3)

Photo: Source VGP 2007.

Corinthian alabastron (4)

Photo: Source VGP 2007.

Corinthian alabastron (5)

Photo: Mário Novais, Lisbon.

CyPriot BARREL-JUG (6)

Photo: Source VGP 2007.

AtTIC BlaCK-Figured Band-CUP (7)

Photo by the author.

AtTiC BlaCk-Figured CUP (8)

Photo: Arco-Íris, Lisbon.

ATtic BLACK-Figured hydria (9)

Photo: Arco-Íris, Lisbon.

ATtiC BLACK-FiguRED HYdRia (after cleaning)

Photo: Arco-Íris, Lisbon.

Panathenaic amphora (10)

Photo: Source VGP 2007.

Panathenaic amphora (10)

Photo by the author.

ATtIC BLACK-FIGURED FAT LEKYTHOS (11)

Photo by the author.

AtTiC BLACK-Figured LeKYTHOS (12)

Photo by the author. 
XVII. 1

XVII. 2

XVII. 3

XVII. 4

XVIII. 1-3

XIX. 1

XIX. 2

XX. 1

XX. 2

XXI

XXII-XXIII

XXIV-XXV

XXVI-XXVII

XXVIII-XXXII

XXXIII

XXXIV
ATtiC BLACK-FigURED LEKYTHOS (13)

Photo by the author.

ATtiC BLACK-FigURED LEKYTHOS (14)

Photo by the author.

Attic black-figured Lekythos (15)

Photo: Source VGP 2007.

Attic black-figured Lekythos (16) Photo by the author.

ATtiC BLACK-FigURED LEKYTHOS (17) Photo: Mário Novais, Lisbon.

ATtic white LeKYTHos (18)

Photo: Source VGP 2007.

Attic White Lekythos (19)

Photo: Source VGP 2007.

Attic white lekythos (20)

Photo by the author.

AtTic White LeKythos (21)

Photo by the author.

Fragment of AN ATTIC RED-FiguRED COLUMN-

-KRATER (22)

Photo: Mário Novais, Lisbon.

NOLAN AMPHORA (23)

Photo: Arco-Íris, Lisbon.

NOLAN AMPHORA (24)

Photo: Arco-Íris, Lisbon.

AtTiC RED-Figured COLUMn-KRATER (25)

Photo: Arco-Íris, Lisbon.

AtTiC Red-Figured CaLyX-KRater (26)

Photo: Gulbenkian Foundation, Lisbon.

ATTIC RED-FigurEd SQUAT-LEKYTHOS (before restoration) (27)

Photo: F. Aroso, Oporto.

ATTIC RED-FigurED SQUAT LEKYTHOS (after restoration) (27)

Photo: Arteluz, Lisbon. 
GREEK VASES IN PORTUGAL

XXXV-XXXVII

XXXVIII

XXXIX

XL

XLI

XLII. 1-2

XLIII. 1-2

XLIV. 1

XLIV. 2

XLV. 1

XLV. 2

XLV. 3

XLV. 4

XLVI

XLVII

XLVIII. 1,2-XLIX. 1,2 ItALIOTE LEBES GaMiKos (40)

Photo: Arteluz, Lisbon.

$\mathbf{L}$

LI-LIII

LIV-LVIII

Attic Red-Figured Pelike (30)

AtTiC Red-Figured Pelike (30)

AtTIC BLACK CUP-SKYPhos (34)

Photo by the author.

Attic black-cup (33)

Photo by the author.

AtTiC SQUat-LeKythos (35)

AtTiC SQuat-lekythos (36)

Photo by the author.

Attic sQuat lekythos (37)

Photo by the author.

Attic oinochoe (38)

Photo by the author.

Photo: Arteluz, Lisbon.

Apulian Pelike (42)

Paestan hydria (43)
ATtiC RED-Figured BELl-KRater (28)

Photo: Mário Novais, Lisbon.

ATTIC RED-FigurEd BELL-KRATER (29)

Photo: Source VGP 2007.

ATTIC RED-FIGURED BELL-KRATER (29)

Photo: Source VGP 2007.

Photo: Source VGP 2007.

Photo: Mário Novais, Lisbon.

ATTIC RED-FIGURED SKYPHOS (31)

Photo: Mário Novais, Lisbon.

ATtiC RED-FIGURED SKYPHOS (32)

Photo: Dr. F. Ribeiro da Silva, Oporto

Photo: Mário Novais, Lisbon.

ITALIOTE RED-FIGURED SQUAT-LEKYTHOS (before restoration) (39)

Photo: F. Aroso, Oporto.

ITALIOTE RED-FIGURED SQUAT-LEKYTHOS (after restoration) (39)

ITALIOTE RED-FIGURED FISH PLATE (41)

Photo: Source VGP 2007.

Photo: Mário Novais, Lisbon.

Photo by the author. 
GREEK VASES IN PORTUGAL

LIX-LXI

LXII-LXIII.1,2

LXIV

LXV.I

LXV.2

LXVI.I

LXVI.2

Campanian CALYX-KRater (44)

Photo by the autor.

Campanian Bell-KRater (45)

Photo: Source VGP 2007.

Small Striped amphora (perhaps Cumaean) (46)

Photo by the author.

Hellenistic Miniature pointed amphora (47)

Photo: Mário Novais, Lisbon.

Hellenistic Miniature POINTEd aMphora (48)

Photo: Mário Novais, Lisbon.

Hellenistic lacrimatorium (49)

Photo by the author.

ROMAN LACRIMATORIUM (50))

Photo: Mário Novais, Lisbon. 


\section{A B B R E V I A T I O N S}

$A B V$

$A R V$

CVA

$J H S$

Notícia $i$

Notícia ii

Notícia iii

$V G P$
Sir John Beazley, Attic Black-Figure Vase-Painters. Oxford, at the Clarendon Press, 1956.

Sir John Beazley, Attic Red-Figure Vase-Painters. Oxford, at the Clarendon Press, 1942.

Corpus Vasorum Antiquorum. Paris and elsewhere, from 1922.

Journal of Hellenic Studies. London

Maria Helena da Rocha Pereira, 'Notícia sobre Vasos Gregos Existentes em Portugal (1.a Parte)'. Reprinted from Humanitas, vols. VII-VIII, Coimbra, 1956.

Maria Helena da Rocha Pereira, 'Notícia sobre Vasos Gregos Existentes em Portugal. II.a Parte'. Reprinted from Humanitas, vols. XI-XII, Coimbra, 1959.

Maria Helena da Rocha Pereira, 'Notícia sobre Vasos

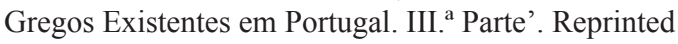
from Conimbriga, vol. I, Coimbra, 1959.

Maria Helena da Rocha Pereira, 'Una krátera pintada campaniense'. Reprinted from Archivo Español de Arqueología, vol. XXXI, n. ${ }^{\circ}$ 97-98, Madrid, 1958 (published 1959).

Maria Helena da Rocha Pereira (ed.), Vasos Gregos em Portugal. Aquém das Colunas de Hércules, Lisbon, National Archaeological Museum, 2007. 


\section{N T R O D U C T I O N}

Among the Greek vases in this country there are a few which turned up in excavations and others which were acquired abroad. We think it will be interesting to give first a historical account of the findings and of the way in which collections were formed in the last century, before we start analysing the vases themselves.

\section{1 - VASES FOUND AT ALCÁCER DO SAL}

In 1874, the very year Schliemann started excavating at Mycenae thus opening up vast areas to our knowledge of early Hellenic civilization, there accidentally came to light in Portugal a set of objects amongst which were a few Greek vases.

There is no point in emphasizing here the significance of such a discovery for reconstructing the historical profile of ancient Salacia, and for tracing the extension of commercial and colonial power of the Greeks (1), nor would it be useful to retrace the story

(1) Near Setúbal, at Chibanes, a small fragment was turned up (quoted by Leite de Vasconcelos, História do Museu Etnológico Português (1893-1914), Lisboa, Imprensa Nacional, 1915, pp. 184 and 188). Other examples will be referred to later on. 
of the successive turning up of such precious documents. Both subjects have already been adequately dealt with (1).

Here we only need mention that Mr. António de Faria Gentil, owner of the estate where such findings had turned up, signed an agreement, two years later, with the Marques de Sousa Holstein, then Superintendent of the Lisbon Academy of Fine Arts, entrusting the findings to the Portuguese Government and granting it permission for digging in the site. Twenty years later more casual findings turned up. These were endowed to the Museum of Alcácer do Sal. In 1925 systematical excavations were finally started under the direction of Virgílio Correia.

Meanwhile the findings already acquired by the Government were divided between the Artillery Museum and the Museum «das Janelas Verdes» (both in Lisbon) and only many years later did they enter the Ethnological Museum of the University of Lisbon, where they are at present kept.

Of the several objects we shall concern ourselves with Greek Vases only.

(1) Respectively by Virgílio Correia, 'Alcácer do Sal. Esboço de uma Monografia', Biblos, vi (1930), 40-59, and Maria de Lourdes Costa Arthur, 'Necrópolis de Alcácer-do-Sal (Colección del Prof. Dr. Francisco Gentil)' in Crónica del II. Congreso Arqueológico Nacional, Madrid, 1951, Cartagena, 1952, pp. 369-380. See also a few scattered notices in Virgílio Correia, 'Fechos de Cinturão da Nécropole de Alcácer do Sal', Biblos, i (1925), 319-326; 'Uma Conferência sobre a Nécropole de Alcácer do Sal', Biblos, i (1925), 347-363; 'As Fíbulas da Nécropole de Alcácer do Sal', Biblos, vi (1930), 504-509. 
The appearance of vases at Alcácer do Sal did not pass unnoticed in this country nor abroad. Nevertheless it took a long time to ascertain their origin as we shall presently see.

A notice about them by the architect J. da Silva together with a drawing of the main vase appeared in the Boletim de Architectura e de Archeologia da Real Associação dos Architectos Civis e Archeologos Portugueses, 2." série, 1875, Tomo I, n. ${ }^{\circ}$ 6, pp. 91-92 and pl. 10, under the heading 'Uma necrópolis romana em Portugal', whence we give the following extract:

...'quatro urnas de diversas grandezas no estilo etrusco... Porém a maior, a mais bem conservada, da qual a estampa $n .^{\circ} 10$ do presente número dá perfeita ideia das pinturas que a ornam na grandeza do original, mostrando-se na composição do assunto o destino da urna, conforme o que se praticava nas cerimónias fúnebres da Etrúria. Esta urna tem 0,25 centímetros de alto e o contorno com 0,51 centímetros'...

After interpreting the picture in (A) as a last meal prepared by two youths and a woman, while an old man points to a tree wherefrom a man in the prime of life is detaching a leaf in order to provide a symbol for separation, he goes on to say that the picture on (B), although the dark background has almost vanished owing to dampness, still shows a 
little of the outline of three figures. These, he says, were two naked warriors, one of them wearing a hood with two flaps falling down on his shoulders; the other with his head uncovered and a horse's tail. Between them there was a woman holding an oval shield in her left hand and apparently trying to protect the warrior with the hood and also raising her right arm in order to prevent the other warrior from attacking him. There was a clearly drawn difference between the two athletes in order to assign them to different races. Such scenes, he goes on to say, were represented on Etruscan incineration urns in order to make it clear what a continuous struggle our life is and how only death puts an end to it. This was shown by the breaking off of the combat as a result of the intervention of the figure who stops the struggle in which a human being loses his life. The Romans employed Greek artists in the manufacture of urns, but their designs were less bloodthirsty than the ones by the Etruscans which consisted only of combats. Moreover, he continues, the period when paintings were executed in black instead of being left in the actual colour of the clay corresponds to the period when Greek art was at its height.

This summary should suffice to give an idea of the author's almost incredible powers of invention in interpreting the pictures on the vase.

As to the label of Etruscan which was given to the vases this is not surprising since the first famous 
specimens of Hellenic pottery having turned up in Etruscan sites - Vulci — such was supposed to be their origin during the second and third decade of the nineteenth century and this denomination prevailed for a long time.

J. da Silva did not take long to give the news of their appearance to foreign colleagues as we can gather from a letter published in Bulletin Monumental, Paris, 1875, n. ${ }^{\circ}$, p. 372 :

'Dans la séance de l'Institut Archéologique de Rome, dont j'ai parlé plus haut, on s'est également occupé de vases étrusques, trouvés dans la nécropole d'Alcácer do Sol [sic]. Les membres de cette société ont manifesté le désir d'avoir un calque soigneusement exécuté des figures qui y sont représentées...'

Some archaeologists raised doubts about the true origin of the vases, as is clearly shown in a letter from Desjardins, published in Bulletin Monumental, Paris, 1875, n. ${ }^{\circ}$, pp. 471-472:

'...Il ne faut voir dans ce vase qu'une oeuvre de la décadence, qui a été exécutée en Sicile ou en Italie, et qui appartient à l'école grecque et non pas aux Étrusques...'

The Earl of Conestabile spoke in much the same way, as we can read in the Crónica inserted in the 
Boletim d'Architectura e de Archeologia, 1876, n. ${ }^{\circ}$ 12, p. 194 (1):

'...C'est très curieux de rencontrer un vase peint de la série greco-italique dans une découverte du Portugal. Je crois que cela arrive pour la première fois et doit attirer vraiment l'attention des archéologues, à cause de la propagation commerciale de ces mouvements céramographiques vers un pays auquel on ne pensait pas du tout...'.

The same classification of Italo-Greek, alternating with Etruscan, in a confusion not difficult to understand at that time was adopted by Emile Cartailhac who experienced the same astonishment at the appearance of products from such an origin in the remotest corner of the Peninsula - to such an extent that he felt that a fraud had been perpetrated though, as he himself asserted, this was not confirmed by the slightest evidence. This is clearly shown in his

(1) From the same year 1876 there is a report by Filipe Simões published in $O$ Instituto, Coimbra, xxxiii (1876), n. ${ }^{\circ} 1-6,191-195$, which still speaks of Etruscan vases:

'...vasos de barro dos que denominam etruscos, muito notáveis pela perfeição do fabrico e pela ornamentação. Eram quatro estes vasos, porém infelizmente os trabalhadores que andavam na excavação partiram dois. Os outros dois restantes são um acetabulum ou oxybaphon e um peliké [sic].'

(I owe this reference to Mr. J. M. Bairrão Oleiro). 
Les Âges Préhistoriques de l'Espagne et du Portugal, Paris, 1886, pp. 252-261, where, after referring to 'des vases en terre peints Italo-Grecs' he goes on to say:

'Cette découverte de vases dits étrusques n'était point passée inaperçue au Portugal; le Boletim d'architectura les publia, mais cette feuille était peu répandue hors du pays... Ces produits exotiques sont au moins, les uns du III $^{\circ}$ siècle avant notre ère, les autres du VI ${ }^{\circ}$. Ce ne sont pas les seuls objets dûs à l'importation... On admet aujourd'hui que les Étrusques après la ruine de leur puissance maritime, se tournèrent vers le nord, pour trouver le débit des armes, outils, objects d'art... Ce commerce... aurait-il été plus étendu qu'on ne le soupçonnait? ...La céramique, avec personnages figurés, bien connue sous l'appellation d'Étrusque, va nous révéler d'autres faits plus importants pour nous. On sait que ces vases étaient fort souvent copiés d'après de très anciens modèles grecs...'.

Estácio da Veiga, referring to the findings at Alcácer do Sal in his work Antiguidades Monumentais do Algarve, Lisboa, 1886, vol. IV, p. 267 seqq. hesitates about their true provenance:

'...Duas urnas de barro de cor escura, com figuras emblemáticas pintadas, das vulgarmente 
chamadas etruscas, ou gregas, sendo desiguais nas dimensões...'.

F. Alves Pereira, in a note to an essay published in $O$ Archeologo Português, xx, 1-16, entitled 'Novas Figuras de Guerreiros Lusitanos Descritas pelo Dr. L. de Figueiredo Guerra', contented himself with the prudent remark:

'Tudo isto é ante-romano.'

But in 1905, at least, the vases were already known to be Greek and chronology was tolerably exact, for Leite de Vasconcelos in the 'Notice Sommaire sur le Musée Ethnologique Portugais, Lisbonne' published in the above-mentioned journal, $\mathrm{x}, 1905, \mathrm{n} .{ }^{\circ} 3-5,65-71$, and later included in the História do Museu Etnológico Português, says that the Museum possessed 'des vases grecs, trouvés à Alcácer do Sal'.

In the História in the chapter about 'Antiguidades Nacionais', pp. 187-188, while speaking of the famous necropolis, he clearly states:

'...Acharam-se aí armas e instrumentos agrários de ferro, loiças gregas do século IVIII a.C, objectos de adorno corporal (fíbulas e braceletes)... A loiça grega relaciona-se com outros achados da mesma natureza feitos no Sul de Portugal.' 
Strange though the terminology may sound, we must acknowledge that this classification and chronology are more accurate.

In 1924, J. de C. Serra Ráfols, who was entrusted with the task of writing the article on Alcácer do Sal for Ebert's Reallexikon der Vorgeschichte, assigned the vases to the last third of the fourth century B.C., though hesitating between Italic and Greek provenance (1).

Therefore it is not surprising that Virgílio Correia, once he had the opportunity of meeting Prof. Beazley at the Museo Arqueológico of Madrid, put the question to him. This enabled him to state in Biblos, i, 1925, 324:

'...Embora já recentemente, rompendo com a mais lata denominação de vasos ítalo-gregos, alguns autores classificassem estas crateras como gregas, eu tive a boa sorte de ouvir confirmar em Madrid, pela boca de uma autoridade en cerâmica helénica, o Professor Beazley, da Universidade de Oxford, que tais vasos deviam denominar-se áticos, pois que áticos eram, da decadência e da primeira metade do século IV'.

(1) 'Aus dem letzten Drittel des 4. Jh. v. Chr.: besonders dadurch interessant, weil sie die Südgrenze der gennanten Kultur markiert... Die Funde bestehen aus ... und Keramik, unter der zwei jüngere rotfigurige Kratere griech. oder ital. Herkunft. Die rotfigurigen Vasen... sind wahrscheinlich älter als das lezte Drittel des 4. Jh. v. Chr.....' (Vol. i, p. 96). 
Henceforward, every writer dealing with these vases (1) adopted, as was to be expected, the same classification and chronology.

Such is, in broad outline, the history of the Greek Vases found at Alcácer do Sal most of which are now preserved, together with a few non-painted plates, cups or fragments from Moura and Elvas in the Museu Etnológico, Lisbon, in two glass cases in the main room (our numbers 28. 30. 31. 41). The rest were endowed to the University of Coimbra by Prof. F. Gentil, the present owner of the estate where they were found, in 1958. It consists of two vases: a red-figured bell-krater (29) and a red-figured skyphos (32).

Generally speaking it is important to stress the fact that, excepting perhaps the fish-plate, all of them are Attic, and not Italiote. This is most important for the history of the contacts between the natives of the Iberian Peninsula and the Hellenes in those faraway times.

\section{2 - VASES ACQUIRED ABROAD}

Most of the Greek Vases kept in this country were acquired abroad and came here at various dates.

(1) Among whom A. A. Mendes Correia, in a short reference on p. 160 of vol. i of the História de Portugal edited by Damião Peres; and, in greater detail, García y Bellido, Los Hallazgos Griegos en España, Madrid, 1936, pp. 101-102, and Hispania Graeca, Barcelona, 1948, vol. ii, pp. 187-188, and also Maria de Lourdes Costa Arthur, op. cit., pp. 369-380. 
During the nineteenth century three collections were thus formed. We have been able to trace them back, though not in their entirety, since two of them were dispersed in the course of time.

The first to enter this country appears to have been the Duke of Palmella's collection (Lisbon), which came in the early thirties of last century. It consists of eighteen vases said to have been brought from the Herculaneum and Pompei excavations by Dom Manuel and Dom Alexandre de Souza Holstein (1), the present owner's ancestors, who were Portuguese Ambassadors in Rome at the time. They entered this country shortly after Queen Maria II's accession, therefore not much later than 1834. They are now kept in one of the Duke's palaces in Lisbon. The vases are: an Attic black-figured cup (7); a Panathenaic amphora (10); an Attic black-figured fat lekythos (11); four Attic black-figured lekythoi (12. 13. 14. 16); two Attic white lekythoi (20. 21); an Attic black cup (33); an Attic black cup-skyphos (34); two

(1) Dom Manuel de Souza married Dona Mariana Leopoldina, Princess of Holstein and Countess of Sanfré, in Piedmont, and was ambassador in Rome; of this marriage was born Dom Alexandre de Souza Holstein who was also ambassador in Rome. A son of his, Dom Pedro, became the first Duke of Palmella, and the latter's second-born child became the Marques de Sousa Holstein (I owe these biographical data to the kindness of the Duke of Palmella). This Marques de Souza Holstein is precisely the nobleman who as Superintendant of the Lisbon Academy of Fine Arts signed an agreement with Mr. António de Faria Gentil, entrusting the findings of Alcácer do Sal to the Portuguese Government and granting it permission for digging in the site. Thus the same illustrious family is connected with the acquisition of a great part of the specimens of Greek pottery in this country. 
Attic squat lekythoi (36. 37); an oinochoe (38); a Paestan hydria (43); a Campanian calyx-krater (44); a striped amphora, perhaps Cumaean (46); and a lacrimatorium (49).

Emil Hübner, in an appendix to his book Die antiken Bildwerke in Madrid, 1862, p. 329, and later in a notice on Portuguese antiques included in Bullettino dell' Istituto di Corrispondenza Archeologica, Rome, 1862, 199, refers to this collection complaining that he had not been able to see it. A short, unsigned note (1) about it may be read in Archivo Pittoresco, Lisbon, 1861, iv, 48. According to a notice given by Mr. J. M. Bairräo Oleiro in Humanitas, Coimbra, vii-viii (1955-1956), 278, Miss Maria de Lourdes Bártolo read a paper on the vases, which has remained unpublished, at a meeting of the Portuguese Archaeological Society (Lisbon).

Next comes the Royal Collection, whose history is as follows:

Emil Hübner, Die antiken Bildwerke in Madrid,

(1) In that note there is a description of a Greek vase in the Vienna Museum. The accompanying drawing is taken from Witte et Lenormant, L'Étude des Monuments Céramographiques. After a few words on the subject, the anonymous author says:

'Na casa dos duques de Palmella deve existir um vaso semelhante, que foi comprado pelo duque velho no leilão do espólio da marquesa de Niza, D. Eugénia'.

Now, if the likeness between the two vases lay in the subject (Athena at her toilet, flanked by two women) the vase is no longer in the Duke's collection. If only the shape was common to both, then it would be the calyx-krater studied later on in this book (44). 
Berlin, 1862, Anhang, p. 328 seqq., gives an account of classic works in this country. After a short reference to the Duke of Palmella's collection, to which however he had no access (as said above), he writes on p. 331 :

'Die Sammlung des Königs Dom Fernando (im Palast der Necessidades) enthält einige aus Neapel stammende Vasen, welche der verstorbene König Dom Pedro V geschenkt erhalten hatte, ferner Silber-, Thon- und Glasgefässe aus Portugal. Ich übergebe hier alle die bloss antiquarisch interessanten Stücke und verzeichne nur die mit Bildwerken versehenen. Die kleine Zahl bezieht sich auf die Reihenfolge der ausführlichen Beschreibung im Bullettino; die in Klammern bei den Vasen aus Jahns Tafel der Vasenform.'

As the description which follows is in an abridged form, we will now turn to the Bullettino dell'Istituto di Corrispondenza Archeologica, Roma, 1862, 193-207, from which we will give the extracts relating to our subject:

'1. Tre piccoli vasetti ad un manico di forme elegante, ma con semplici disegni di figure rosse su fondo nero. Sull'una vi è una fanciulla seduta coi bracci stesi, come se fosse 
per giuocare, nel rovescio ve n'è un'altra simile in piedi.

8. Due vasi a fondo nero con figure rosse, di provenienza nolana, come sembra, e di stile bello; regalo d'un nunzio apostolico a S.M. L'uno, di circa 45 centimetri d'altezza (forma 53 della tavola del Jahn, Münchener Vasensammlung, $1854,8^{\circ}$ ) mostra sulla parte antica quattro figure in piedi, cioè dalla parte sinistra una donna vestita di chitone, senz'ale, voltata a d., stendendo con ambo le mani una tenia verso un giovane guerriero ignudo, voltato a s., che porta il pileo conico comune ai naviganti, la lancia nella d., e nella s. il grande scudo rotondo ornato di corona d'alloro. Segue una vittoria alata, a d., alzante nella d. un vaso nero ad un manico, onde versa il liquore in una patera, che tiene nella s., presentandola ad altro giovane ignudo voltato a s., dirimpetto a lei, e che sta col capo scoperto (i capelli cinge una benda), alzando colla d. l'elmo; nella s. tiene la lancia, la clamide gli pende sulle spalle. Sul rovescio vi sono quattro giovani inviluppati in mantelli. L'orlo superiore è ornato d'una serie d'animali, leoni, cinghiali, cigni; anch'essi figure nere su fondo rosso (1).

(1) This is an obvious mistake. The German summary in Die antiken Bildwerke in Madrid reads 'ebenfalls roth auf schwarz'. 
L'altro vaso della medesima forma e di stile somigliante, alto circa 50 centimetri, e sul diritto mostra puranche quattro figure, tiasoti, a ciò che pare, occupati in una funzione notturna. A s. una donna vestita di chitone con premura procede a d.; porta nel braccio d. un trepiede con piatto per porvi sopra una torce. A d. procede pure un giovane ignudo, portante una torce nella d. e volgendo la testa addietro verso la donna, che segue, vestita di chitone, danzante ed alzando nella s. il tamburino, che gli cuopre la spalla; porta nella s. il tirso e volge la testa addietro verso la donna danzante. Sul rovescio si vedono tre giovani invilupatti ed una donna. L'orlo superiore è ornato dei medesimi animali che quello dei primo vaso, ma mostrano un'esecuzione meno elegante.

13. Vaso di terra cotta rossa, senza manichi, disgraziatamente frammentato, dimodochè mancha quasi della metà, ornato di bassi rilievi della stessa perfezione di stile che quelli di Tarragona menzionati nel Bullettino di 1860 , p. 168, ma d'argomento più raro. In mezzo vi si vede un'ara con sacrifizio ardente; a s. di essa sta un sacerdote, ignudo di sopra; a d. una giovane vestita di chitone, più a s. dietro del sacerdote la statua d'una dea, che non saprei definire. Seguono ai due lati varie altre persone, alcune damneggiate, di modo chè la loro 
significazione resta incerta. Spero dall'insigne liberalità dell'augusto possessore di poter dar più tardi un disegno di quest'interessante monumentino che fu scoperto a Alcácer do Sal, l'antica Salacia.'

The collection therefore consisted of two column-kraters, three small lekythoi and a broken vase, all of them red-figured.

Although after the death of the king consort, in 1868, most of his artistic collections were bequeathed to his second wife, the Countess of Edla, the Greek vases apparently remained in the palace. But they were lost trace of in 1910 when the monarchy ceased to exist.

The 'Fundação da Casa de Bragança', to whom the remaining antiques were entrusted later on, has by now recovered three small pieces which we shall presently analyse. Nevertheless, these do not correspond exactly with Hübner's description, since there are only two lekythoi and a lebes gamikos. None of the lekythoi has a seated woman on one side and a standing woman on the other. It may be that he muddled up his notes and was referring to one of the extant lekythoi. The lebes gamikos must have been a later addition to the collection. If so, there is still a lekythos missing besides the two column-kraters and the broken vase found at Alcácer do Sal, the last one being a most puzzling case since its description resembles very closely the scene in the 
bell-krater in the Ethnological Museum from the same provenance, and, moreover, there is no record of findings coming to light at the ancient Salacia before 1874, while Hübner's report dates back twelve years earlier (1).

The two extant squat lekythoi (27. 39) were found with broken necks and handles partly broken; two mouths were adjoining them. They have now been restored, though not very correctly. The plates show them before and after restoration.

Both these and the lebes gamikos (40) are kept in the Palácio Ducal de Vila Viçosa (Évora) in glass cases in the basement rooms, under the heading 'King Louis' Collection'.

In the second half of the same century another small collection had been gathered together in Monserrate Palace near Sintra (Lisbon) by an English gentleman, Sir Francis Cook (2). It was seen by W. Gurlitt, who wrote a notice (3) about it in Archäologische Zeitung, Berlin, 1868, Neue Folge,

(1) Filipe Simões (O Instituto, xxxiii [1876], 192), only says that 'em várias épocas haviam aparecido nas cercanias desta vila moedas e outras antiguidades romanas que fizeram supor ser aquele o sítio da antiga Salacia, apesar de não haver perfeita concordância com o Itinerário de Antonino'.

(2) Monserrate palace had been purchased by an ancestor of Sir Francis Cook in 1853, and embellished and transformed into a kind of museum by this Englishman, who afterwards became Viscount of Monserrate. Byron stayed there during his sojourn in Sintra. Oleiro.

(3) I owe this reference to my colleague, Mr. J. M. Bairrão 
I. Band, pp. 84-87. This is how his account begins:

'Hr. Fr. Cook in London, woselbst er ebenfalls Sammlungen aller Art besitzt, hat in seiner Villa an dem oben bezeichneten Ort eine Reihe antiker Gegenstände von sehr ungleichem Werth, darunter auch viel modernes, zusammengebracht, von denen ich im Folgenden ein möglichst kurzes Verzeichnis, mit absichtlichem Ausschluss alles sicher modernen, gebe'.

He then proceeds to describe four statues, eleven busts and a relief. On p. 85 he analyses four Greek vases (two Nolan amphorae, a red-figured column-krater and a black-figured hydria) and he closes his account with a reference to a few other statues and sarcophagi.

We have been lucky enough to locate all these vases (respectively 23. 24. 25. 9), now in private collections in Lisbon or its suburbs. But at the time they were auctioned, some years ago, there were apparently ten or eleven. It seems likely that Sir Francis Cook increased his collection after the publication of Gurlitt's notice, either with his London specimens or with further acquisitions. In any case, no trace of these has yet been found.

A fourth collection was acquired by Leite de Vasconcelos in 1905, according to his own statement 
in vol. xi of $O$ Archeologo Português). It came from the ruins of Mycenae and Argos and other non-specified Greek sites and has been preserved in two glass cases in the Lisbon Ethnological Museum ever since.

It consists of a Mycenaean one-handled cup (1) and some fragments from the same origin, two Corinthian alabastra (3.4), a Cypriot barrel-jug (6), an Attic black-figured lekythos (15), two white lekythoi (18. 19), an Attic squat lekythos (35), two miniature pointed amphorae (47. 48) and a lacrimatorium (50).

Besides these collections there are a few more vases in museums or in private hands which were acquired in the London or Paris market, or elsewhere, as will be stated in the appropriate place.

(1) This group is included in the list of 'Acquisições do Museu Etnológico Português' from April 1905: '...Também entrou no Museu uma colecção de mais de quatrocentos objectos arqueológicos que adquiri na Grécia, Itália, Suíça, França e Hespanha' (Vol. xi (1906), 92). 'Uma taça grega dos séculos III-II a.C, que obteve em Roma' is also referred to in vol. xviii, 1913, 163, among the acquisitions from October 1912.

The same items are mentioned again by Leite de Vasconcelos in his História do Museu Etnológico Português, pp. 252-263, under the heading 'Objectos estrangeiros antigos e modernos': '...Da Grécia antiga: fragmentos cerâmicos pintados, vindos das ruínas de Micenas e Argos; vasinhos do século V e IV a.C...' and also p. 103 of the same book. 
M Y C E N A E A N 


\section{ONE-HANDLED CUP (PI. I. 1,2)}

From Mycenae or Argos. Portuguese Ethnogical Museum (The University of Lisbon). Published in Notícia i, pl. 2.

The oldest Greek vase in this country is a one-handled cup from late Mycenaean. Its shape is described and illustrated by A. Furumark, The Mycenaean Pottery, p. 48, type n. ${ }^{\circ} 22$.

Decoration consists of concentric circles near the foot and a broader band decorated with a pattern which is repeated all round the cup. It is very similar to a cup in the British Museum, C 631, from Enkomi (CVA. British Museum, 1, pl. 5.12-26; Stubbings, Mycenaean Pottery from the Levant, pl. xii, n. ${ }^{\circ}$ 13). The only difference is that in our case the ornament is the U-pattern (1) which is a frequent one in late Mycenaean.

In another glass case there are three trays full of fragments from the Mycenaean and Geometric periods.

(1) Cf. A. Furumark, The Mycenaean Pottery, p. 345, fig. 58, n. ${ }^{\circ} 45$, and pp. 351-352. 
G E O M E T R I C 
2. G E O M E T R I C J U G (PI. II).

Presented to our Prime Minister by the Prime Minister of Greece during a State visit in 1954. Noticia $i$, pl. 1.

A jug from the Geometric period, from Athens and from the eighth century B.C. It is a specimen of what Prof. Beazley calls 'bird and bird-seed motif. Its surface is entirely decorated with several linear drawings among which stand out the stylized horses on the frieze on the belly. The largest bands are decorated with the meander-pattern, triglyphs, lozenges, undulate vertical and horizontal lines. Chevrons dominate on the smaller bands. The foot is decorated with small dots.

Many of these motifs were already in use during Mycenaean times (1). But the shape of the vase, with ovoid belly and bright neck of almost the same length, its continuous decoration, with alternating

(1) Cf. A. Furumark, The Mycenaean Pottery, chapter on 'The Elements of Mycenaean Decoration', pp. 236-429. 
straight and wavy lines, narrow and large bands (1) and the insertion of an animal pattern, all this characterizes the vase as geometric and gives to the whole a harmony which clearly reveals its Attic origin.

(1) The style is clearly defined, in opposition to the preceding one, by V. R. d'A. Desborough, Protogeometric Pottery, p. 125. He takes it that the Geometric style introduces new shapes and alterations of old ones; that the clay-ground technique disappears, but the simple dark ground technique is increasingly interrupted by systems of bands, more closely related to the general effect of the vase, the neck and belly areas receiving particular attention. The main new motives, he adds, are the meander and the multiple chevron. 
C O R I N T H I A N 
3.4. ALABASTRA(PI.III.1 and 2).

From Greece. Portuguese Ethnological Museum (The University of Lisbon). Published in Noticia $i$, pl. 2.

Both alabastra are Corinthian, from the end of the seventh century B.C. The one on the left has a small-circle pattern. The one on the right has large bands alternating with circles.

Both patterns are widespread and well-known ones. See, among many others, CVA. Danemark, 2, pl. 94 (n. ${ }^{\circ} 12$ and 13).

\section{A L A B A S T RON(PI. III.3).}

A Corinthian alabastron from the last quarter of the seventh century B.C., bought in Paris by its present owner, Mr. Álvaro de Brée, Barcarena (Lisbon).

The typical rosettes and a bird can still be seen, though the painting has almost vanished. The rosette on the mouth is easily recognizable. 
C Y P R I O T 
6. B A R R E L - J U G (PI. IV).

From Greece. Portuguese Ethnological Museum (The University of Lisbon). Notícia $i$, pl. 2.

Small vase, with large belly, decorated with sets of narrow stripes flanked by larger stripes, with short neck and a handle. It is from Cyprus, from about 600 B.C. 
A T T IC B L A C K-F I G U R E 
7. B A N D - C U P (PII. V, VI).

Attic black-figured band-cup or rather bandskyphos. Said to have been brought from Herculaneum and Pompei excavations. Lisbon, Palmella Collection. Noticia ii, pll. 19, 20.

Third quarter of the sixth century B.C.

A fawn grazing; on each side a panther.

Most cups of this time represent hunting scenes or just animals, as here.

For a similar motif see CVA. Napoli, Museo Nazionale, pl. 16; CVA. British Museum, fasc. 3, pl. 16, 9-10.

\section{C U P (PII. VII-IX).}

Attic black-figured deep cup. Mr. L. Gilbert's private collection, Lisbon. Bought in London at Spink's by its present owner. Notícia iii, pll. 18, 19, 20. It has no lips, very deep bowl, low foot and a ridge at the juncture of bowl and foot. This characterizes it as a kylix of a rather unusual shape and dates it to 550 B.C. or the third quarter of the century. 
A.

A single combat between two onlookers.

The warriors are fully armed with casks, short chitons, greaves, swords and shields. The one on the right is kneeling on his left knee but his head is turned to the enemy; he has raised up his shield in order to protect his body and right leg and has also raised his left arm. The warrior on the left stands with his shield covering his left arm and has raised his right arm. The onlookers are mantled youths. The himation of the one on the right has folds in diagonal direction.

B.

A similar scene, warriors and onlookers almost in the same position. But the warriors are naked.

Underneath each handle there is a swan.

A very similar scene can be seen on a lekythos in Sydney 49.07, published by Prof. Trendall in JHS. 1xxi (1951), 183, fig. 3 c. Also on a black-figured hydria by Sakonides in the University of Berlin (Andreas Rumpf, Sakonides, pl. 76).

Prof. Beazley finds a near parallel to it in a cup Athens, Ceramicus Museum, inv. 20 ( $A B V$. p. 456 n. ${ }^{\circ}$ 5: Jb. 61-62, pi. 9, 24), probably by the same painter, and even by the same potter (although the 
bowl is shallower and the profile of the foot-plate different, the style of the shape is very similar). The same may be said of the cup Athens 358, which must be by the same potter ( $A B V$. p. 456: A. Bloesch, F.A.S. pl. 1,2). As to drawing, he continues, the Ceramicus cup is related to the New York amphoriskos 41.162.176 and the Painter of Munich 1842 ( $A B V$. pp. 453-6).

White is used for borders of shields, bands and feathers of the swans.

\section{HYDRIA (PII. X, XI).}

Attic black-figured hydria belonging to $\mathrm{Mr}$. Manuel Vinhas, Estoril (Lisbon). Formerly part of Sir Francis Cook's collection, Monserrate Palace, Sintra (Lisbon). Notícia ii, pll. 22, 23.

This is a hydria of type I, of the last quarter of the sixth century B.C. (cf. Richter-Milne, Shapes and Names of Athenian Vases, figs. 78-79). Unfortunately, the painting has been much restored, so that only the horses on the left have been preserved in their original state. It represents Achilles and Troilos, and a chariot-scene on the shoulder. The vase has been included in the Leagros Group by Prof. Sir John Beazley, with the warning 'restored' $\left(A B V . \mathrm{n}^{\circ} 26\right)$. By that time, it was considered to be lost (1).

(1) Since the publication of Noticia ii, it has been included in the second edition (Marburg, 1960) of Brommer's Vasenlisten, p. 268, n. ${ }^{\circ} 7$. 
This vase has therefore an academic interest only. Indeed, it has a curious story. It first belonged to Campanari, then to Rogers, in whose collection it was numbered $372(1)$, and then to Harding. It was published by Jahn, Telephos und Troilos, pl. 2, and E. Gerhard, Vases Étrusques et Campaniens du Musée Royal de Berlin, Berlin, 1843, pl. E, 5-6, and also described by Secondiano Campanari in Bullettino dell'Istituto di Corrispondenza Archeologica, Roma, 1834, pp. 234-238. This is how Campanari describes it, pp. 235-236:

'È in mezzo del quadro un largo basamento formato di grosse piètre quadrate in bell'ordine disposte su cui ne sorge altro minore similmente composto, dove s'inalza il simulacro di Apollo. Intonso è il nume, ha le mani ambe levate, e chiaro vi si legge de canto il nome di $A \Pi O \Lambda \Lambda \Omega N$ (2).

and, on p. 238, he describes the scene on the shoulder:

'L'altro soggetto figurato sotto il collo del vaso è una ripetizione di quelle tante corse di cocchi di cui sono pieni i vasi destinati in premio

(1) It has been described in the sale catalogue of the Samuel Roger's Collection, Christie and Manson, April 28., 1856 ff., p. 25 (I owe this reference to Dr. Dietrich von Bothmer).

(2) In this as well as in the coming inscriptions, archaic Greek letters have been replaced by classic ones, owing to printing difficulties. 
a' vincitori di siffatti giuochi. Solo abbiamo a dolerci che questo bel vaso, sebbene integro, abbia un poco sofferto nella vernice rossastra che gli cuopre il fondo; del qual danno sentiva ancora alcun poco la testa della statua di Apollo, prima che da me fosse fatto ristorare. Del resto è però conservato, e pare che il tempo stesso e l'acqua di cui era coperto il sepolcro dove fu ritrovato, abbiano voluto rispettare si bel monumento'.

This account has only a historical interest, since the interpretation of the scene is clearly wrong. But it already speaks of restoration, and this is important. Gerhard knew the vase in apparently the same condition. The above-mentioned plate shows the small figure with left arm raised and fingers pointing upwards. The right arm has been gripped by Achilles. The inscription $A X I \Lambda \Lambda E Y \Sigma$, above the horses's heads, has been preserved. Between Achilles' head and his raised left arm stands $\Pi A P I \Sigma$ and alongside the small figure we can read $A \Pi O \Lambda \Lambda \Omega N$. The warrior behind the altar holds his spear slightly inclined.

This is how Gerhard describes it, pp. 45-46:

5-6. Tod des Troilos. Hydria des Herrn Samuel Rogers zu London... Das Gefäss ist ergänzt, dargestellt dass, der von Herrn Rogers mir gestatteten Prüfung gemäss, statt der Inschrift 


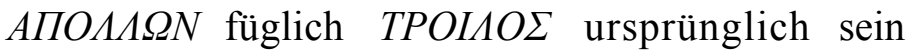
kann; von den übrigen Inschriften, die unangerührt blieben, mag $A X I \Lambda \Lambda E Y \Sigma$ beglaubt sein, dagegen wir uns erlauben, die Inschrift ПАРІ $\Sigma$ die als Name des Paris jedenfalls A A $\varnothing \sigma \alpha v-$ $\delta \rho o \varsigma$ heissen müsste, bis zur Nachweisung ihrer Echtheit für untergeschoben $\mathrm{zu}$ halten. Dieses vorausgesetzt, ist der von Achill auf Apollo's Altar an Troilos verübte Frevel unverkennbar; aus dem skäischen Thor kommt rechterseits Hektor mit später Hülfe herbei, während linkerseits zugleich mit Achill's Wagen vielleicht auch Beistand der Griechischen vermuthet werden darf.'

The vase must have been still in the same condition when Gurlitt saw it in 1868, for he says (op. cit., p. 86):

'Grosse Vase mit drei Henkeln (Form N. 34 bei O. Jahn); alterthümlicher Stil. Zwei Streifen schwarzer Figuren mit weiss und braun auf rothem Grunde. a) zwischen den beiden Henkeln (ich gehe bei der Beschreibung von links nach rechts): eine bekleidete Frau, wie alle Frauen mit weissem Gesicht und Händen, hält in der Linken einen langen Stab mit einem Knopf. Sie beugt sich etwas herab zu einem Greise mit weissem Bart und Haar, welcher auf einer Säule sitzt und den Kopf zu ihr zurückwendet, 
auch er hat in der Linken einen langen Stab. In der Mitte besteigt ein Krieger nach rechts hin den Schlachtwagen; er hat den Schild über den Rücken gehängt, die Rechte hält eine Lanze, die linke die Zügel des Viergespannes. Die Pferde sind schwarz, eins weiss, sämmtlich mit brauner Mähne und braunem Schweif. Hinter den Pferden, nahe beim Wagen, steht eine Frau, auf welche der Krieger blickt. Sie reicht die ausgestreckte Linke zum Abschied. Die rechte Hand ist, wie beschwörend, gehoben. Doch kann man den Gestus in Verbindung mit dem der linken Hand auch einfach auf den Abschied beziehen. Weiter rechts, gegen die Pferde gekehrt, sitzt ein Greis mit weissem Bart und Haar, einen Stab in der Hand, hinter ihm ein Krieger in voller Rüstung, mit Helm, Schild und Lanze.-a) (ebenfalls von links nach rechts) zunächst die Vordertheile von vier Pferden mit weissem Zaumwerk. Es folgt eine grosse Kriegergestalt, welche durch eine Inschrift links vom Kopfe als $A X I \Lambda \Lambda E Y \Sigma$ bezeichnet ist. Auf dem Kopfe, von dem reiche Locken auf die rechte Schulter herabwellen, trägt er einen grossen Helm mit grossem, braunem Kamm und langem Helmschweif, der Brustharnisch ist weiss, ebenso die braungeränderten Beinschienen. Der linke Fuss tritt in starker Biegung auf einen Mauerabstaz, welcher aus zwei Lagen Quadersteinen gebildet ist. Seine hochgehobene Linke hat die Rechte 
eines nackten Knaben von sehr gefälliger Bildung erfasst, welcher noch höher auf einer zweiten Stufe dieses Absatzes steht und reisst sie in die Höhe über den Kopf des Knaben hinaus. Die Rechte zückt ein langes Messer gegen ihn. Auch dieser Knabe, dessen Linke flehend in die Höhe gerichtet ist, ist durch eine Beischrift näher bezeichnet. Am linken Arm des Achilleus entlang steht etwas undeutlich, aber doch unzweifelhaft der Name $\Pi A P I \Sigma$. Rechts von diesem Mauerabsatz, der hinten gerade abschliesst, ist die Hälfte eines gerüsteten Kriegers mit Helm, Schild und Lanze sichtbar. Es folgt ein Pfeiler, unten weiss, oben schwarz, welcher durch die ganze Hobe des Streifens hindurchgeht und ihn in zwei Theile theilt. Rechts von denselben zeigen sich wieder die Vordertheile eines Viergespanns, dann ein Krieger in vollständiger Rüstung. Darüber sehen von einer zinnengekrönten Mauer ein behelmter und ein unbehelmter Kopf herab, letzterer auffallend roh.'

In its present condition, only one of the three above-mentioned inscriptions has been preserved: this is the one reading $A X I \Lambda \Lambda E Y \Sigma$, obviously referring to the warrior between the horses and the altar. Troilos only shows his left arm, so that Achilles' gesture has no point. The warrior behind the altar has had his spear repainted (now it is quite upright) and the column in the middle has also been repainted; 
there is a horse's head on the shelf on the right, which is new. The chariot-scene has been left untouched.

The second restoration also shows several layers of painting, which have badly damaged the drawing. As we have already said, only the horses on the left (excepting the extreme upper corner of the scene) are original.

\section{PANATHENAIC AMPHORA (PII. XII-XIV)}

Panathenaic amphora with lid (which seems to belong) but not a prize one. Said to have been brought from Herculaneum and Pompei excavations. Lisbon, Palmella Collection. Notícia ii, pll. 1, 2, 3. End of the sixth century B.C.

A.

Athena in the typical position of the prize panathenaic amphorae: she is raising one heel from the ground and wears an aegis covered with scales and trimmed with small serpents. She is short and stout and wears a simple peplos. The device on the shield is a ketos-head. She is flanked by two columns. These are not surmounted by cocks, as this is only a non-official imitation of the panathenaics.

B.

Wrestling-scene. Two bearded athletes wrestling in the middle. On the left, a trainer 
or judge, also bearded, wrapped in his himation, stands watching, holding a staff in one hand and three sprigs in the other. On the right, another athlete, his right arm slightly raised, looks on. On the wall hangs a garment.

This is quite a common scene on the backs of Panathenaic amphorae. Cf. CVA. British Museum B 140, fasc. i, III He, pl. 4, n. ${ }^{\circ}$ 2; B. 604, III Hf, pl. 2, n. ${ }^{\circ} 4$ and B. 603, III Hf, pl. 2, n. ${ }^{\circ}$ 5: $C V A$. Louvre, Inv. Campana 192, Catal. F 276, fasc. v, III Hg, pl. 1, 5-6; CVA. Bruxelles, Inv. A 13b, fasc. i, III He, pl. 13,5 $C V A$. Museo Nazionale Tarquiniense, Inv. n. ${ }^{\circ}$ 627, fasc. i, III H, pl. 17,2; $C V A$. Madrid, Inv. 32647, fasc. i, III He, pl. 28, 1-b.

11. F A T L E KY T H O S (PI. XV. 1,2).

Said to have been brought from Herculaneum and Pompei excavations. Lisbon, Palmella Collection. Notícia ii, pll. 12 and 13. 1. Last quarter of the sixth century B.C.

A youth in the middle starting to run; on either side clothed youths.

It belongs to the Fat-Runner Group, according to Prof. Beazley (see his Attic Black-Figure Vase-Painters, pp. 459-460). 
12. LEKYTHOS (PI. XVI. 1,2, 3).

Said to have been brought from Herculaneum and Pompei excavations. Lisbon, Palmella Collection. Noticia ii, pll. 13.2, 14, 15 . Earlier part of the fifth century B.C.

A man reclining on a couch and three women sitting. A foliage decoration fills in the empty spaces above.

The vase belongs to a well-known series of symposion scenes, which Prof. Beazley ascribes to the Haimon Group. He lists some of them in $A B V$. n. ${ }^{\circ}$ 551-553, in addition to the ones mentioned by C. H. E. Haspels, Attic Black-Figured Lekythoi, i. 241-247. The Painter's style is defined ibidem, i. 130-141.

13. 14. LEKYTHOI (PI. XVII. 1,2).

Two Attic black-figured lekythoi with palmette decoration said to have been brought from Herculaneum and Pompei excavations. Lisbon, Palmella Collection. Notícia ii, pl. 16. 1 and 2. First half of the fifth century B.C.

A widespread pattern. See, among many examples, CVA. Deutschland, Braunschweig, pl. 11, n. ${ }^{\circ} 12,13 ;$ CVA. Wien, Sammlung Matsch, pl. 6, n. ${ }^{\circ} 1,2 ; C V A$. Baltimore, Robinson Collection, III He, pl. 38, n. $^{\circ} 5$. 
These lekythoi certainly come from the Beldam workshop, and may have been painted by the Beldam Painter himself. See C. H. E. Haspels, Attic Black-Figured Lekythoi, i. 185.

\section{L E K Y T H O S (PI. XVII. 3).}

Attic black-figured lekythos with palmette decoration. From Greece. Portuguese Ethnological Museum (The University of Lisbon). Noticia $i$, p1. 3. First quarter of the fifth century B.C.

For a similar pattern see CVA. Danemark, Copenhague, Musée National, pl. 112, n. ${ }^{\circ}$ 15-16.

16. LEKYTHOS (PI. XVII. 4).

Attic black-figured lekythos with coarse ivy decoration. Said to have been brought from Herculaneum and Pompei excavations. Lisbon, Palmella Collection. Notícia ii, pl. 16. 3. Fifth century B.C. Restored.

Many instances of this decoration, with better drawing, are to be found.

See, for instance: CVA. Bruxelles, Musées Royaux, pl. 1, n. ${ }^{\circ} 13 ; C V A$. Copenhague, Musée National, pl. 112, n. ${ }^{\circ} 17$ and 18; CVA. Cambridge, Fitzwilliam Museum, i, pl. 22, n. ${ }^{\circ} 33$; CVA. Pologne, Cracovie, Collection de l'Université, pl. 1, n. ${ }^{\circ}$; CVA. Deutschland, Braunschweig, pl. 11, n. ${ }^{\circ} 15$. 
An Attic black-figured lekythos bought in London at Sotheby's, on January 16th, 1956, by Mr. E. Malta (Lisbon). Noticia iii, pll. 9, 10, 11. The catalogue dates it to c. 530 B.C.

Its shape, however, with sharp shoulder-edge, long neck, shallow mouth, and tall, tapering body, the drawing of the figures and the 'wet-incised' lines with three turns below the picture are characteristic of the lekythoi from the Beldam workshop (1), so that we may date it back to the second quarter of the fifth century. I take it to be from the Beldam workshop, not from the Beldam Painter himself.

For lists of lekythoi from the same workshop, see C. H. Emilie Haspels, Attic Black-Figured Lekythoi, i. 266-269, supplemented by Prof. Beazley, $A B V$.

(1) Its technique is described by Miss Haspels, op. cit., i. 171:

'Below the scene - the chief mark of this workshop - two groups of two or three "wet-incised" lines. To make these lines, the painter after the black paint had been put on, placed the vase once more on the wheel, and turned it while holding a blunt tool against the vase. Often he did not succeed in making beginning and end meet and then he simply spun on, so that instead of three rings we get a "snake" with three turns, coiling round the vase. These lines were put on before clay and paint were fired and before they were quite dry; that is why I call them "wet-incised".

Prof. Beazley called this Painter Beldam after the subject of the much discussed black-figured lekythos Athens 1229 (see Miss Haspels, op. cit., i. 170). 
pp. 586-587 and 709. For characteristics of his style, see C. H. Emilie Haspels, ibidem, pp. 171, 178, 185. The workshop of the Beldam Painter is dealt with ibidem, pp. 170-191.

A very similar subject on a lekythos at Laon 37.903, is mentioned by Prof. Beazley, $A B V$. p. 709: Dionysos on donkey, with satyr and maenad (1).

Here it is not Dionysos, but a woman riding a donkey preceded by a maenad and followed by a satyr.

The maenad wears a chiton and a panther-skin on her shoulders. She carries a thyrsos horizontally in her right hand and holds a snake in her left hand. She is looking towards the donkey. Behind her and behind the woman who is riding are branches. The satyr is naked and has a long beard. With his right hand he urges the donkey on; his left hand is raised with a finger sticking out (2).

White is used for face, neck, arms and hands of the maenad; also for the mouth of the donkey. Below the picture, the characteristic 'wet-incised' lines; on the shoulder, a ray decoration.

(1) This was a common subject. See, for instance, a cup in the Louvre F. 133, published in JHS. $\operatorname{lxxv}(1955)$, pl. XIII. 3, and also a lekythos at Canterbury University College 2 (quoted by Prof. A. D. Trendall in JHS.

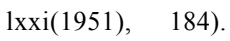

(2) A characteristic detail. Cf. Miss Haspels, Attic Black-Figured Lekythoi i. 172:

\footnotetext{
'The figures have queer stunted hands with the thumbs sticking out in a purposeless way'.
} 
ATt T C White LEKYThOI 
18. WH I T E LEKY THOS (PL XIX. 1).

Attic white lekythos with ivy-decoration. From Greece. Portuguese Ethnological Museum (The University of Lisbon). Notícia $i$, pl. 3.

Second quarter of the fifth century B.C.

There are many examples of this pattern. See, among many others, CVA. Bruxelles, 2, pl. 1.

19. W H T E L E K Y T H O (PI. XIX. 2).

From Greece. Portuguese Ethnological Museum (The University of Lisbon). Notícia $i$, pl. 3.

A man with a long beard holding a sitck. On the right, a stele.

On the shoulder, a ray decoration. On the upper part of the body, a meander pattern.

The tapering straight body, deep shallow mouth and the sharp angle between shoulder and body, characterize the vase as a product of the Beldam workshop, though not of the Beldam Painter himself. See C.H.E. Haspels, Attic Black-Figured Lekythoi, i. 170-191, for characterization of this style.

The date is about 460 B.C. 
20. W H I T E L E K Y T H O S (PI. XX. 1).

Said to have been brought from Herculaneum and Pompei excavations. Lisbon, Palmella Collection. Noticia ii, pl. 16.4. Second or third quarter of the fifth century B.C. No recognizable drawing (perhaps a woman, a stele, and another figure).

Probably Tymbos Goup, according to Prof. Beazley.

21. W H I T E L E K Y T H O S (PI. XX. 2).

Said to have been brought from Herculaneum and Pompei excavations. Lisbon, Palmella Collection. Noticia ii, pl. 17.2. Second or third quarter of the fifth century B.C. No recognizable drawing. Probably Tymbos Group, according to Prof. Beazley. 
A T TIC RED-FIGURE 
22. FRAGMENT OF A COLUMN-KRATER (PI. XXI).

Provenance unknown. Barcarena (Lisbon), Mr. Álvaro de Brée's private collection.

The head of a komast. The upper chest is visible, and also his raised right arm. According to Prof. Beazley the remains on the right seem to be the handle and part of the lip of a cup held up in his left hand. The same scholar assigns this fragment to one of the early mannerists, the Agrigento Painter, also second quarter to middle of the fifth century. For a list of works by this painter see his $A R V$. pp. 377-382, 959, 968. He was a companion of the Pig and Leningrad painters and it is to be remarked that no less than forty-one vases out of sixty-eight which have so far been identified are column-kraters, so that this seems to have been a favourite form with him.

23. NOLA N A M P H O R A (PII. XXII, XXIII)

Formerly in Sir Francis Cook's collection at the Monserrate Palace, Sintra (Lisbon). Now in Mr. L. Gilbert's private collection, Lisbon. Notícia iii, pll. 14,15. About 480 B.C. 
The vase has been described by W. Gurlitt in Archaeologische Zeitung, Berlin, xxvi (1868), 85, in the following way:

'a) Ein ganz bekleideter, bärtirger Priester, den Epheukranz im Haar, hält in der Rechten nach links hin einen Krug, aus dem er auf einem brennenden Altar zu spenden im Begriffe steht. Die Linke hält einen langen Thyrsus.

b) Ein nackter, jugendlicher Satyr mit langem Schweif streckt die Linke wie tastend vor, ebenso das linke Bein; das rechte ist zurückgebogen, in der rechten hält er einen Krug'.

Now let us analyse it.

\section{A. Dionysos.}

The god is dressed, as usual, in a sleeved chiton and over it he has a himation round his right side and over his left arm; his hair is tied with a wreath falling in a curl on each shoulder; and he has a long beard. He carries a thyrsos in his left hand and with the right holds a kantharos with which he is about to pour a libation over an altar on the left, the top of which is in the form of an Ionic capital. Below, a meander pattern alternating with saltire-squares.

\section{B. A satyr.}

The satyr is moving right with outstreched arms. He is naked and has a long beard. In 
his right hand he holds an oinochoe. Below, the same meander pattern alternating with saltire-squares.

The subject from (A) is to be found on a Nolan amphora by the Pan Painter (Tillyard, Hope Vases, pl. 9,90) and on another Nolan amphora from the Ripe Archaic period, also on Tillyard, Hope Vases, pl. 9, 91. This only shows that it was a common subject since the style is different.

Prof. Beazley, who has seen photographs of the vase, assigns it to the Dutuit Painter (1). From the list of his works in $A R V$. pp. 205-206 and 955, one can easily see that Dionysos and satyrs were often drawn by this painter (for example, a neck-amphora in Berlin 2330 - A. Dionysos; B, maenad - an oinochoe in London E 511, Dionysos and satyr; an oinochoe in the Louvre G 240, Dionysos and maenad; and perhaps a small neck-amphora in Berlin inv. 3309, A, Dionysos with satyr and maenad, B, rider and man).

Miss Richter calls the Dutuit Painter one of 'the most attractive' among late archaic pot painters and 'a singularly gracious personality' (2). His fine

(1) Named after an oinochoe in the Petit Palais 315 (Artemis caressing a fawn - cf. G. Richter, Attic Red-Figured Vases, p. 73) once in the Dutuit Collection (studied by Prof. Beazley, 'The Master of the Dutuit Oinochoe', JHS. xxxiii(1913), 106-110).

(2) Attic Red-Figured Vases, p. 73. 
drawing conveys an impression of serene, yet alert self-restraint, which is characteristic of late archaic at its best.

24. NOLANAM PHORA (PII. XXIV, XXV).

Formerly in Sir Francis Cook's collection at the Monserrate Palace, Sintra (Lisbon). Now in Mr. L. Gilbert's private collection, Lisbon. Notícia iii, pll. 16, 17. About 470-450 B.C.

This is how Gurlitt, op. cit., pp. 85-86, describes it:

'a) Ein Jüngling in langem Mantel, aus welchem nur der rechte Arm und die rechte Schulter hervorsehen, hält in der vorgestreckten Rechten einen langen Stab; der linke Arm, vom Mantel bedeckt, ist in die Seite gestemmt.

b) Ein nackter Jüngling, mit einer schmalen, braunen Binde im Haar, ist im Begriff, in's Bad zu steigen. Er steht gerade gegen den Beschauer, der Kopf ist etwas nach links gewandt, die Arme sind vor der Brust gekreuzt und die Hände auf die Schulter gelegt. Das einfache Motiv ist mit grosser Meisterschaft ausgeführt, man fühlt es förmlich mit, wie ein leiser Schauder den Körper in dem kühlen Räume durchzieht. Rechts neben ihm liegt der Mantel und der lange Stab, oben hängt ein Schlauch.' 
Now let us analyse the vase :

A.

An athlete with his arms folded over his chest. On the right, a column with his clothes on top. Leaning against the wall, a stick. Hanging high on the wall are a sponge, aryballos and strigil. Below, a meander pattern.

B.

A youth wearing a himation round his body and over his left arm, and holding a stick with his right hand. Below, the same meander pattern.

Prof. Beazley, who has seen photographs of this amphora, assigns it to the Alkimachos Painter (1) and compares it with another Nolan in Plovdiv (Revue Arch. xxxviii (1951), 32-38, whence Bulletin de Correspondance Hellénique, 1957, pp. 150 and 155, and fig. 12), and for the youth on (B), a Nolan amphora in London 1928. 1.1757 (CVA. pl. 46,2 and pl. 51,3), which he now believes to be from the painter's own hand, and not only in his manner, as he formerly assumed. For the clothes on the pillar he compares Gallatin's Nolan by the same painter (CVA. Gallatin, pl. 54,1).

(1) Named after a kalos-name which appears on one of his vases (see G. Richter, Attic Red-Figured Vases, p. 110). 
The list of the painter's identified vases is to be found in Prof. Beazley's Attic Red-Figured Vase-Painters, pp. 356-359 and 958 (totalling up to fifty vases, after the above-mentioned correction).

His favourite subjects seem to have been warriors, komastai, maenads and satyrs. Nevertheless there are other representations of athletes, besides the present vase, on a neck-amphora at New-York, Gallatin Collection (A, jumper; B, trainer) and on a column-krater in Rhodes 12063 (A, horse-race; $\mathrm{B}$, athletes and trainer).

25. C O L U M N - K R A T E R (PII. XXVI, XXVII)

Attic red-figured column-krater in the Early Free Style, about 460 B.C. Formerly in Sir Francis Cook's collection at the Monserrate Palace, Sintra (Lisbon). Now in Mr. L. Gilbert's private collection, Lisbon. Noticia iii, pll. 12, 13.

The vase is described by Gurlitt, op. cit., p. 86, as follows:

'...Eine Vase (in der Form ähnlich Nr. 35 bei O. Jahn), rothe Figuren auf schwarzem Grunde. Ich konnte nur die eine Seite sehen. Ein Greis, in den Mantel gehüllt, mit langem Stock in der Linken, ist $\mathrm{zu}$ einem nackten Jüngling rechts hin gewandt, dessen Kopf, rechter und linker Arm und linkes Bein am Oberschenkel mit schmalen, braunen Bändern 
umwunden ist, welche zusammengeknottet mit langen Enden ausflattern.'

Let us see it closer.

A. A paidotribes and a victorious athlete. The paidotribes has a himation round his right side and over his left arm from which it falls in long folds; he holds in his right hand the forked wand of his office. He wears a laurel crown on his head. The youth on the right is naked but is also crowned. Hanging from his arms and tied round arms and legs are tainiai characterizing him as a victor (1).

B. A youth wrapped in his himation, holding a staff in his right hand.

The drawing of the folds very much recalls the painter of a pelike now in Cambridge, Fitzwilliam Museum (Tillyard, Hope Vases, pl. 12, 98) and a column-krater now in New York, Gallatin Collection (Tillyard, Hope Vases, pl. 20, 127), both by the Pig Painter. Prof. Beazley, who has seen pictures of the vase, also assigns it to this artist.

The Pig Painter (2) (formerly called See-saw

(1) There are many such representations, for example on the panathenaic by the Kleophrades Painter in Boston (JHS. xxxvi (1916), 130-131; $V A$ p. 42; Caskey B, p1. 5) (pointed out to me by Prof. Beazley).

(2) His name is derived from the two pigs in his picture of Odysseus and Eumaios on a pelike in Cambridge, according to G. M. A. Richter, Attic Red-Figured Vases, p. 96. 
Painter) is a mannerist who continues the style of Myson (1). About forty vases have been assigned to him up to now, half of which are column-kraters, a shape that seems to have been a favourite with him. He sometimes liked to paint athletes on the obverse of his vases. So on the column-krater in Castle Ashby, Northampton, and on the one in Brussels R 305, CVA. pl. 16.1 and 17.1. A man and a boy victor can be seen on the column-krater at the Cabinet des Médailles 414, De Ridder, pl. 16.

A list of his works is to be found in Prof. Beazley, ARV. pp. 370-372.

26. C A L Y X - K R A T E R (PII. XXVIII-XXXII).

This is a famous vase in the free style, about 440 B.C., found at Agrigento and assigned to the Coghill Painter by Prof. Sir John Beazley, ARV. p. 688, 1, after the name of its first owner.

From the Coghill Collection, it came to the Hope Collection, whence, after the great auction sale in 1917 at Christie's, it became the possession of Mr. C. S. Gulbenkian, who kept it in his Paris home, along with other precious antiques. In 1958, the vase came to this country together with many other works of art which the Gulbenkian Trust has brought here, and are to be housed in a museum to be erected in Lisbon. At present, the vase is stored in

(1) See Prof. Beazley, ARV. p. 370. 
a palace belonging to the same Trust, at Oeiras (Lisbon), whence it will be transferred to the projected Museum within a few years.

The vase has a long bibliography to its credit, which I shall now enumerate:

James Millingen, Peintures Antiques de Vases Grecs de la Collection de Sir John Coghill Bart, Rome, 1817, pp. 1-6 and plates I, II, III. Guigniaut, Religions de l'Antiquité, pl. 159, n. ${ }^{\circ} 606$.

Inghirami, Monumenti Etruschi, V, 1824, pll. XIII-XIV.

Otto Jahn, 'Griechische Vasenbilder', Archaeologische Zeitung, Berlin, III. Jahrgang, 1845, Sp. 27-30.

C. Bursian, 'Raub der Leukippidem', Archaeologische Zeitung, Berlin, X. Jahrgang, 1852, Sp. 433-444 and Tafel XLI.

Thiersch, Veterum artificum opera ueterum poetarum carminibus explicata, II and Archaeologische Zeitung, 1852, pl. 41.

H. Heydemann, 'Due Vasi di Ruvo', Annali dell'Istituto di Corrispondenza Archeologica, Roma, 1885, vol. lvii, p. 165, n. 1.

Ernst Kuhnert, 'Eine neue Leukippidenvase', Jahrbuch des kaiserlich Deutschen Archaeologischen Instituts, Band ii, 1888, p. 273. Otto Benndorf und George Niemann, 'Das Heroon von Gjölbaschi-Trysa', Sonderdruck 
aus dem Jahrbuch der Kunsthistorischen Sammlungen des Allerhöchsten Kaiserhauses, Wien, 1889, p. 615, n. 1.

Roscher, Lexikon, Band III, Sp. 1993, s. u. 'Leukippiden'.

Carl Robert, Die Marathonsschlacht in der Poikile und weiteres über Polygnot, Achtzehntes Winckelmannsprogramm, Halle, Max Niemeyer, 1895, p. 59.

P. Hartwig, 'Die Wiederkehr der Kora auf einem Vasenbilde aus Falerii', Mitteilungen des kaiserlich Deutschen Archaeologischen Instituts, Römische Abteilung, Band xii, Rom, 1897, p. 102, n. 1.

Salomon Reinach, Répertoire des vases peints grecs et étrusques. Paris, Ernest Leroux, Éditeur, vol. ii, 1900, pp. 1-2.

Studniczka, Jahrbuch, xxxi (1916), 211, fig. 26. Christie's Catalogue, July 13, 1917, pl. I, n. ${ }^{\circ} 55$. E. M. W. Tillyard, The Hope Vases. Cambridge, 1923, pp. 65-68 and pll. 17 and 18.

J. D. Beazley, Attic Red-Figure Vase-Painters. Oxford University Press, 1942, p. 688.

G. M. A. Richter, Attic Red-Figured Vases. A Survey. Metropolitan Museum of Art. New Haven, Yale University Press, 1946, p. 130 and n. 110 and 111 .

Notícia ii, pll. 24, 25, 26, 27, 28.

Brommer, Vasenlisten $^{2}$, p. 360, n. $^{\circ} 3$. 
Let us now single out the main points in the history of the interpretation of the vase. As we can see, it was first published by Millingen. He explained its main drawing as a representation of a victory in the Pythian Games, illustrating an ode of Pindar. Thiersch followed the same trend. The right explanation was provided by Jahn, who described the upper register as the Rape of the Leucippidae. Comparison with the Meidias' vase in the British Museum, which bears inscriptions with the names of the figures, enabled him to get a better understanding of the whole scene. Bursian developed this comparison and even produced a further parallel with a relief on a sarcophagus found in the neighbourhood of Kertsch, also representing the same scene. The several plastic versions of the same mythical event have been compared by Benndorf and Niemann.

A full description of the vase was made by Tillyard, who also provided a thorough discussion of other representations of the rape of the Leucippidae. This is a rather interesting point, since it had been assumed that the vase-paintings derived from a famous picture by Polygnotus in the Anakeion at Athens, mentioned — but not described-by Pausanias 1. 18. 1. Tillyard argues at length that no common source may be assigned to the vases and the Trysa frieze and, anyhow, there would be no need to assume that the vase-painters worked on a major model whenever they wanted to illustrate a mythical scene. 
The upper register shows the rape of the Leucippidae. On each side the centre is occupied by a quadriga led by one of the Dioscuroi carrying off one of the Leucippidae. Behind the horses stands Apollo on side (A) and a woman in a Doric chiton on side (B).

On side (A), on the right, a youth wearing a chlamys, petasos and boots, and holding two spears in his right hand, raises his left arm, and at the same time turns his head back to the chariot as if he wanted to lead the way. On the left is a woman running in the direction opposite to the chariot, but her head is still turned back to its occupants, as if to take leave of them. Next to her, to the left, are three girls running. The one in the middle is stretching out her hands towards the others. On the opposite side, sits a bearded man, holding a spear in his right hand and wearing a laurel wreath on his head; he is sitting on a rock and is dressed in a himation. Towards him runs a girl with both arms outstretched, but her head turned to the chariot behind her.

The identification of most of the figures is open to doubt, although the general meaning of the scene is clear.

Jahn suggested that the only god present at the scene was Apollo, standing behind a chariot (A) and that the woman to the left of the same might be Philodice, the mother of the Leucippidae. He identified the man preceding it as Chrysippos, an attendant of the Dioscuroi. He considered the seated man 
on the other side to be Leucippus, to whom a girl brings the news of the rape. On the opposite side, there is a group of three girls, who are companions of the Leucippidae. Maybe the one in the middle is Arsinoe, the third daughter of Leucippus, as Tillyard suggests.

The lower register has always been said to represent a Bacchic scene since Millingen first published it.

On side (A) there are two pairs of satyrs and maenads. The satyr on the left stretches his arms towards a maenad, who holds a wine-skin in her right outstretched arm and a thyrsos with an ivy-spray in her left. The maenad on the right also holds a thyrsos in her left and she is running away from a satyr with outstretched arms.

On side (B) a satyr with a panther-skin on his left arm runs between two maenads, the one on the left carrying a thyrsos in her left hand and a wine-skin in her right, the one on the right running in the opposite direction with a burning torch in her left hand.

Both scenes are full of pathos and movement. An egg-pattern band separates the two registers. Above, oblique palmettes and below a meander-pattern alternating with a saltire-square.

Some slight restorations have been noticed by Tillyard in the seated man and the girl running towards him, in the egg-pattern below these two, in the maenad on the left, on side (B), and in the satyr on side (A). 
Prof. Beazley assigned this calyx-krater to the Coghill Painter, to whom he ascribes two further vases, both hydriai, one in London E 170, and one in Naples RC 157, and, hesitatingly, a volute-krater in New York. Hartwig, when discussing the whole series of kraters decorated in two zones, placed this one at the head of the group. So the Gulbenkian vase is indeed a notable addition to our Museums.

27. S Q U A T L E KY T H O S (PII. XXXIII, XXXIV).

The Royal Collection, Vila Viçosa Palace (Évora). Notícia iii, pll. 1 and 2.

Date is about 400 B.C. The mouth is alien.

It represents a seated woman, with outstreched arms, preparing the wool for spinning. She wears a sleeved chiton and has a himation wrapped round her knees. Her hair is gathered into a knot behind her head; she has a single curl on the side. In front of her, on the ground, is a basket. Behind her, a palmette decoration. Coarse drawing.

28. B E L L - K R A T E R (PII. XXXV-XXXVII).

This is the best known of all the vases found at Alcácer do Sal. It has been reproduced in a print by J. da Silva, Boletim de Architectura e de Archeologia, vol. i, n. ${ }^{\circ}$ 6, 1875, pl. 10, pp. 91-92, and Bulletin Monumental, n. ${ }^{\circ}$ 5, 1875, pp. 471-472; in photographs by A. A. Mendes Correia in História de Por- 
tugal edited by Damião Peres, vol. i, p. 160, and A. de García y Bellido, Hispania Graeca, vol. iii, pl. cxlii; also Notícia i, pll. 6, 7, 8. The Ethnological Museum (The University of Lisbon), where the vase is kept, has issued a postcard with it (1).

As to its shape, it is an Attic bell-krater from the first quarter of the fourth century B.C.

Its interpretation has been a subject of controversy. Putting aside, as entirely fanciful, the one already quoted (2) from J. da Silva, we shall now proceed to examine the principal ones and then give that which seems to us the most probable.

A.

Desjardins, in a letter published in Bulletin Monumental, $\mathrm{n} .{ }^{\circ}$ 5, 1875, 471-472, interpreted the picture on (A) thus:

...'Sur les cinq figures qui forment le sujet, celle qui représente un vieillard du côté gauche, et la prêtresse, mettant le feu au bûcher, sont des plus incorrectes d'ensemble aussi bien que de détails. Les trois autres, avec un mouvement meilleur, ne sont pas plus parfaites dans la reproduction des extrémités... Quant au sujet, il me semble y voir une invocation, faite par

(1) The four vases from Alcácer do Sal are photographed together in a vignette on p. 7 of Carolina Michaëlis de Vasconcelos, Algumas Palavras a Respeito de Púcaros em Portugal, repr. Lisboa, 1957.

(2) See above, p. 3-4. 
les deux personnages, placés aux extrémités du tableau. Tous deux semblent faire un voeu en élevant la main sur un bûcher qu'une prêtresse allume, et que deux jeunes gens attisent'.

Now Filipe Simões, $O$ Instituto, xxiii [1876], 192-193, says:

'O primeiro vaso, de maiores dimensões, tem o bojo ornado com duas cenas mitológicas. A primeira e principal representa um sacrifício. Diante do loureiro sagrado a Apolo está um altar, sobre o qual arde a lenha para o sacrifício. Dois ministros aproximam do altar os espetos com as carnes das vítimas. Três outras figuras parece acompanharem com hinos ou outros cantos sagrados a cerimónia do sacrifício'.

F. Alves Pereira, in a short note to a paper 'Novas Figuras de Guerreiros Lusitanos Descritas pelo Dr. L. de Figueiredo Guerra', O Archeologo Português, $\mathrm{xx}, 14$, deals with the same subject. $\mathrm{He}$ apparently believes that the whole scene takes place indoors, for he states:

'...palmetas pintadas que balizam dos lados a casa cultual. Duas das personagens, que nela figuram, sustentam uns utensílios, que não são senão os espetos utilizados nesta cerimónia do culto doméstico...'. 
Contrarywise, A. García y Bellido, Hispania Graeca, vol. ii, pp. 187-188, plainly sees that it all happens outdoors:

'...una grán crátera... con figuras de buen arte, representaba una escena de sacrificio ante una ara, en un paisaje natural (árboles); actúan dos sacerdotisas asistidas por un mancebo desnudo; en los extremos de la escena un hombre barbado, vestido de larga ropa (izquierda) y un varón joven también vestido de largo (derecha)'.

There is no doubt that this is a sacrifice performed over an altar on top of which lies a pile of wood which is being kindled by a woman in a sleeveless chiton, which has a wave-pattern on the hemline and round the neck and small dots everywhere. With her left arm she is pointing to the right. On the right of the altar a youth in his himation is roasting meat on a spike over the fire. Behind him, two steps above the other people, there is a youth draped in his himation pointing to the scene with raised right arm. To the left of the altar, behind the woman, a small naked boy holds a spike over the altar in order to roast the sacrificial meat. Behind him, on a higher level, is a man in his himation with his right arm pointing to the sacrifice. Behind the altar, to the right, there is a laurel tree. Above the picture are laurel leaves, and beneath a meander and saltire square pattern. 
The laurel tree suggests that this may be a sacrifice to Apollo (1). The two male figures on the higher level appear to be gods, but no clear attributes are assigned to them.

The whole is well-balanced. Centralization of the scene is typical of fourth century vase painting.

A similar picture is to be seen on a krater in the Louvre (2): in the shadow of a small tree a crowned man and two youths are roasting meat; on the right is a god who may be Apollo.

B.

As to the obverse, which is rather damaged, besides the fanciful story J. da Silva built upon it which we mentioned earlier in this book (3), we only know of two interpretations. One of them is given by Filipe Simões, op. cit.:

'Na parte oposta vê-se uma bacante inteiramente nua agitando o tímpano e dançando entre dois sátiros'.

The other one was given by A. García y Bellido, op. cit.:

'En la parte opuesta mainades com tympano danzando entre dos satyros con thyrsos...'.

(1) For a similar device to suggest the cult of Apollo, see CVA. Danemark, Musée National, Copenhague, 4, pl. 147-la.

(2) CVA. France, 8, pl. 35,2.

(3) See above, p. 4. 
There is, as a matter of fact, a maenad with a tympanos between two satyrs who are apparently dancing and holding thyrsoi in their hands.

\section{FRAGMENT OF ANOTHER KRATER}

This must have been a vase similar to the foregoing one. Provenance is the same.

Only the lower part is preserved. A piece of its decoration (a meander pattern and a palmette) and the hemline of a chiton are still to be seen.

Fourteen fragments from the same provenance.

29. BELL-KRATER (PII. X X X V I I I A n d XXXIX).

From Alcácer do Sal. Formerly in Prof. Gentil's Collection. Institute of Archaeology, The University of Coimbra.

Published by M. de Lourdes Costa Arthur, 'Necrópolis de Alcácer do Sal', a reprint from the Crónica del II Congreso Arqueológico Nacional, Madrid, 1951, Cartagena, 1952. Also Notícia $i$, p11. 16, 17, 18 .

This is an Attic bell-krater from the first half of the fourth century B.C.

A. García y Bellido briefly referred to it, Hispania Graeca, vol. ii, pp. 187-188 (1). A fuller account has

(1) 'Una de las kráteras tiene mainades y sathyros con pintura blanca'. 
been provided by M. de Lourdes Costa Arthur in the above-mentioned paper. These are her words:

'...de izquierda a derecha, una bacante, teniendo elevada en la mano izquierda una bandeja y en la derecha una antorcha (?); vuelto hacia ella un sátiro, de gran cola equina, danza. En medio y en situación destacada, otra diosa bacante que tiene, como la primera, el tono de la piel sobresaliendo del blanco de la pintura, sujeto con la mano izquierda el tirso, y a juzgar por el sentido del movimiento, que el artista supo imprimir en la túnica que viste, decimos que está bailando, vuelto hacia otro sátiro que sentado toca un pequeño instrumento de viento; en el reverso, tres personajes envueltos en sus mantos...'.

Now let us look at it more closely.

\section{A. A Bacchic scene.}

In the middle, a maenad in a chiton and an elaborate head-dress, holding a thyrsos in her left hand, is dancing to the music provided by the flute played by a satyr seated on a rock to the right. On the left, another satyr holding a thyrsos with both hands and - as far as the condition of the restored picture allows us to see - also wearing an animal skin, like the one on the right. He and the maenad on the left both seem to feel Bacchic extasis. This maenad is dressed in a chiton and carries a fruit 
plate in her left hand and a torch in her right hand. She wears a fillet on her hair, and so do the satyrs. Above the picture are laurel leaves and below a restored meander pattern.

Relieflines are used on the body of the satyrs. White is used for the uncovered parts of the body of both maenads, for the chiton of the one in the middle and for the rock on the right.

B. Youths.

Three youths draped in their himatia. The two at the sides have one arm raised. The one on the left has an aryballos. Hanging on the wall are writing tablets.

The motif of two or three youths talking is a widespread one for ornamenting the obverses of vases. A picture very similar to this one, but in a finer drawing, may be seen on a calyx-krater in the Cyprus Museum (1).

Bacchic scenes are very common on red-figured vases, the most famous example being the amphora 2344 in Munich by the Kleophrades Painter. Compositions like the one we have just analysed are very frequent. We shall mention only two bell-kraters from Galera (García y Bellido, Hispania Graeca, iii, pl. cxxxvi, 5 and pl. cxxxviii, 7). Moreover the style

(1) Published by Prof. Beazley, 'Some Attic Vases in the Cyprus Museum' from the Proceedings of the British Academy, London, 1937, pi. 8, analysed on p. 49. 
of the drawing and the particular shape of the thyrsoi shows, according to Prof. Beazley, that this is a work from the Black-Thyrsus Painter, a well-known Attic painter from the beginning of the fourth century B.C. The bell-krater from the Gentil Collection is therefore a further work to add to the list which has been established by that distinguished scholar in his Attic Red-Figure Vase-Painters, pp. 878-879 and 966. The list, which Prof. Beazley generously gave us with the additions he made after the publication of the afore-mentioned work, is as follows:

\section{Bell-Kraters}

Louvre G 511. CVA. e pl. 3,1 and 3 .

London 1950.4-26.1. A, Tillyard, Hope Vases p1. 27, 168.

Salonica, 38.576. Robinson, Olynthus 13, pl1. 48-50.

Vienna 624.

Once Lamberg. A, Laborde i pl. 80.

Once Mastrilli. Passed, pl. 215.

Madrid, from Tiitugi. A, Boletín de Excursiones 28, p. 247, fig. 9; A, García y Bellido, pl. 136, right. Sofia. Ivanov Apoloníya. 32-3.

Ancona.

Madrid, from Baena. A, García y Bellido, pl. 133, left.

Salonica 38.513, fragment. Robinson, Olynthus 13, p1. $121, \mathrm{~b}$. 
Granada, Rodríguez Acosta, from Tútugi. Boletín 28, 247 and 250, figs. 10-11; García y Bellido, pi. 138 .

Munich, Bayerlin.

Vatican inv. 9099.

Once Englefield. Passen pl. 212; A, Moses, Englefield, pll. 13-14.

Capua 7538. CVA. p1. 21, 2 and 4-5.

Sofia. A, Izv. Big. 11, 130, fig. 119.

Ostia, fr. Ostia 1 pl. 23, below, right, C.

Naples 918.

London, private collection.

Naples 942. A, Jahreshefte 32, 39.

Oxford 1954. 265, frr. Part, JHS., 59, 34, 83.

Louvre G 523. CVA. e pl. 5, 9-10.

Copenhagen Chr. viii. 83. Antik-Cabinett 1951,75.

Barcelona, from Ampurias. A, García y Bellido, pl. 110, left.

Leningrad (St. 1174). A, Schefold, Untersuchungen, pl. 27,4.

Athens, Pnyx, 328, fr. Hesperia, suppl. X, pl. 33, 328 .

Salonica, 8.235, fr. Robinson, Olynthus 5, pl. $137,361$.

Alicante, fr., from Isla del Campello. Garcia y Bellido, pl. 123, 45, upper right. The fragment ibidem, lower left, may belong.

Salonica 328, fr. Robinson, Olynthus 5, pl. 104,163.

Oxford fr. 


\section{Pelike}

New York GR 524. A, Schefold, Untersuchungen, fig. 80 .

It is interesting to notice that many of this painter's works have been found in the Iberian Peninsula.

30. P E L I K E (PII. XL, XLI).

From Alcácer do Sal. Portuguese Ethnological Museum (The University of Lisbon).

This vase has been reproduced by Leite de Vasconcelos, História do Museu Etnológico Português, fig. 56-56A, p. 367; Ebert, Reallexikon der Vorgeschichte (article 'Alcácer do Sal', by Serra Ráfols), vol. iv, p. 96, pl. 26 b-c; García y Bellido, Hispania Graeca, vol. iii, pl. cxlii; A. Martins Afonso, História da Civilização Portuguesa, p. 21 ; Notícia i, pll. 9, 10.

It is an Attic pelike from the first half of the fourth century B.C. In his already-quoted paper, Filipe Simões complained that:

'No vaso menor não era já possível classificar os assuntos representados de uma e de outra parte do bojo'.

A. García y Bellido, op. cit., calls it 'un pelike de mal-arte... con figuras dionisiacas (delante) y 
dos personajes envueltos en sus mantos (detrás)'. In a closer analysis, we may say that it represents:

A.

A seated maenad, holding a tympanos with both hands, between two youths. The one on the right holds a thyrsos in his right hand. Coarse drawing.

Similar scenes can also be seen in many vases in the Apulian style, for instance, $C V A$. Copenhague, Musée National, 6, pl. 250, 2a and $b$, and pl. 253, la.

B.

Two standing youths, draped in their himatia, and talking to each other.

Such a scene is extremely common on minor vases and also became current in the Apulian style. See, among many others, CVA., Oesterreich, 1, Wien, Kunsthistorisches Museum, pl. 30 and 34; Danemark, Copenhague, Musée National, pl. 250, 2b; 251, la, 2b; pl. 252, 1b, 2b; pl. 253, 2b, 3b; France, Musée du Louvre, 8, pl. 2,6 .

31. S K Y P H O S (PI. XLII. 1,2).

From Alcácer do Sal. Portuguese Ethnological Museum (The University of Lisbon). Published in Notícia i, pll. 11, 12. 
A. García y Bellido, op. laud., refers to it as 'un skyphos con dos personajes envueltos en sus mantos a ambos lados'.

The same motif from the obverse of the red-figured pelike is on both sides of this Attic red-figured skyphos from the first half of the fourth century B.C.

Very coarse drawing.

32. S K Y P H O S (PI. XLIII. 1,2).

From Alcácer do Sal. Formerly in Prof. Gentil's Collection. Institute of Archaeology, The University of Coimbra. Notícia i, pll. 14, 15.

Attic red-figured skyphos, from the first half of the fourth century B.C. It is very similar to the one just described, but in a worse condition, since one of the handles is broken.

It likewise represents on both sides two youths wrapped in their himatia (1). The only difference being that the one on the right holds a staff. On side (B), the other youth holds an object in his hand which is not easily identifiable, because the drawing is exceedingly coarse; perhaps it is a strigil.

(1) Described by M. de Lourdes Costa Arthur, op. cit., as 'un skifos en el cual vemos, por cada uno de los dos lados, dos figuras masculinas envueltas en mantos'. 
ATtiC PLAIN BLACK 
33. C U P (PI. XLIV. 2).

Attic black cup, type C (1).

Said to have been brought from Herculaneum and Pompei excavations. Lisbon, Palmella Collection. Notícia ii, pl. 21. 2.

Fifth century B.C. No decoration.

34. C U P - S Y P H O S (PI. XLIV. 1).

Said to have been brought from Herculaneum and Pompei excavations. Lisbon, Palmella Collection. Notícia ii, pl. 21. 1.

Fifth century B.C. No decoration.

35. S Q U A T L E K Y T H O S (PI. XLV. 1).

From Greece. Portuguese Ethnological Museum (The University of Lisbon). Notícia i, pl. 4.

(1) On forms of Attic cups see Hansjörg Blösch, Formen attischer Schalen von Exekias bis zum Ende des Strengen Stils, Bern, 1940. He defines type $\mathrm{C}$ on page 111 ('Das wesentliche Erkennungszeichen... ist die Form des Schalenfusses, der aus Fussplatte und Fusswulst zusammengesetzt ist') and page 112 ('Zwei Richtungen lassen sich... klar unterscheiden: eine konservative, die zäh an der ursprünglich niedrig gebauten Form festhält, und eine fortschrittende, die sich im Wesentlichen zu höheren und strafferen Gefässen hinentwickelt'). 
Attic squat lekythos from the end of the fifth century B.C. On its belly, the dog-running pattern.

For a similar vase, but with a different, vegetal, decoration, see $C V A$. France, Musée de Sèvres, 13, pl. 46, n. ${ }^{\circ} 4$.

36. S Q U A T L E K Y T H O S (PI. XLV. 2).

Said to have been brought from Herculaneum and Pompei excavations. Lisbon, Palmella Collection. Notícia ii, pl. 18. 3.

Later fifth century B.C. A band of dog-running pattern decoration only.

37. S Q U A T L E K Y T H O S (PI. XLV. 3).

Said to have been brought from Herculaneum and Pompei excavations. Lisbon, Palmella Collection. Notícia ii, pl. 18. 2.

Later fifth or fourth century B.C.

No decoration.

38. O I N O C H O E (PI. XLV. 4).

Said to have been brought from Herculaneum and Pompei excavations. Lisbon, Palmella Collection. Notícia ii, pl. 18. 4.

Miniature oinochoe, shape 3, near to a chous, with trefoil mouth and ivy spray decoration in white. Later fifth or fourth century B.C. 


\section{GREEK VASES IN PORTUGAL}

For a similar vase, see CVA. Cambridge, Fitzwilliam Museum, i, pl. 43, 24.

From the fifth century onwards, this shape becomes quite common in South Italy so that it is difficult to distinguish Attic from Italian ones. On this see CVA. Copenhague, Musée National, fasc. 7, p. 138. 
I T A L I O T E 
39. S Q U A T L E K Y T H O S (PII. XLVI- XVLII).

The Royal Collection, Vila Viçosa Palace (Évora). Noticia iii, pll. 3 and 4. From the early fourth century B.C.

A female head flanked by palmettes. Her hair is in a sakkos; she has a straight nose and curved lower lip. A long curl falls near her ear. Fine drawing.

Human heads were usually represented by themselves in the last phase of Attic, Campanian, Apulian and Etruscan red-figured vases, according to Prof. Beazley (1).

40. L E B E G A I K O S (PII. XLVIII. 1, 2, and XLIX. 1, 2).

The Royal Collection, Vila Viçosa Palace (Évora). Notícia iii, pll. 5, 6, 7, 8 .

This is a late piece. As said above (2), it was not mentioned by Hübner in his account of the Royal Collection.

(1) Etruscan Vase-Painting, Oxford, 1947, p. 10.

(2) See above, p. 12-17. 
It is in Early South Italian Group B (= Early Apulian) therefore from the second quarter of the fourth century B.C. It is almost complete, with lid. It represents:

A.

A woman with a himation draped round a chiton with sleeves holding a garland in her right hand. She wears a necklace and her head is drawn in profile.

B.

A naked youth holding a strigil in his right hand and a himation in his left hand. Body also in three-quarter and head in profile.

Both figures are flanked by a rich palmette decoration which continues underneath the handles. A radiated pattern decorates the lid and upper part of the body of the vase; the vertical portion of the lid has a wave-pattern.

Prof. Trendall, who has seen photographs of this vase, takes it to belong to a large group of minor vases near in style to the Truro Painter, who is one of a number of artists of the second quarter of the fourth century who group around the Lecce Painter (the painter of Lecce 617, 623, 633, 641 = CVA. 2, pll. $15,4.7 ; 12,4 ; 13,6 ; 15,5$ and $8 ; 14,1-15,1)$. Many of these minor vases, he adds, are choes (see Van Hoorn, Choes 404, 414, 466, 401; 396-398), 
two of which (Vienna 978. Zürich 2668 (2382) Van Hoorn, figs. 397 and 519) show a youth with a strigil.

\section{F IS H PLATE (PI. L).}

From Alcácer do Sal. Portuguese Ethnological Museum (The University of Lisbon). Published in Notícia i, pl. 13.

Described by A. García y Bellido, op. laud., as 'un plato con dos peces grandes, otros dos pequenos y un cefalópodo'.

Besides the two big fishes and the cephalopod, four smaller fishes and a further one in the middle can be seen. The sides of the plate are painted with an undulate pattern.

This is an Italiote plate from the fourth century B.C. The theme is very common among vases of such provenance though it may sometines be found on Attic specimens. Fish plates mostly came from workshops in Campania. Many such vases may be seen in CVA. Bruxelles, 3, pl. 1 ; Copenhague, Musée National, 6, pl. 249, etc., but with more accurate drawing. 
A P U L I A N 
42. P E L I K E (PII. LI-LIII).

Apulian pelike of the second half of the fourth century B.C. Provenance unknown. Barcarena (Lisbon), Mr. Álvaro de Brée's private collection. One handle and the mouth are broken and the foot is new. Partly repainted.

A.

On the left, a seated woman wearing a sleeveless chiton and with an elaborate head-dress, a necklace and bracelets on both wrists, is holding a plate in her right hand, and looking to the right at a ball which is being thrown into a basket by a youth standing on the right, who is wearing a himation over his arms. Another ball is about to fall on the plate held by the woman. Above, a flying effeminate Eros with elaborate head-dress, a necklace and bracelets, holds in his right hand a crown which he is going to put on the youth's head. On the extreme right a bird, perhaps a dove; below it a tainia, and then an altar, seem to be entirely modern.

B.

On the left, a woman running after a naked youth. She is dressed in a sleeveless chiton 
(her head is no longer visible) and holds a branch in her right hand and a mirror in her left hand. The youth wears a himation thrown over his left arm. He is looking towards the woman and holds a box in his right hand. His left hand has faded out. A tainia is hanging from the wall on the upper right.

Below the handles, a palmette decoration. Below the figures runs a meander-pattern and on the neck there was a laurel-leaf decoration which is preserved on (B), but has been replaced by rosettes on (A). The legs of the youth and the feet and arms of the woman on (B) and also the whole right side of (A) have been repainted.

Prof. Beazley finds parallels to this vase in the ones published in $C V A$. Bologna iii, IV D r, pl. 11, 3-4 and $C V A$. Copenhagen, VI. 
P A E S T A N 
Said to have been brought from Herculaneum and Pompei excavations. Lisbon, Palmella Collection. Notícia ii, pll. 4, 5, 6, 7, 8, whence A. D. Trendall, Paestan Addenda, pl. 1 d. Schauenburg, Perseus in der Kunst des Altertums, pl. 35, 2. Fourth century B.C.

An apple-tree laden with fruit, in the middle, and a serpent coiled round it. On the left, a Hesperid in peplos overgirt with a dot-pattern and a tainia on her left arm is feeding the serpent from a phiale. With the other hand she is plucking an apple from the tree. Behind her another Hesperid carrying a flat basket full of apples. More apples in a big basket, between the first-named Hesperid and the tree. Still more scattered on the ground, on the right, between the tree and a youth who stands with his left leg on a rock and holds a spear in his left hand, while he plucks an apple from the tree with his right hand. He wears a chlamys round his shoulders, and a garland round his chest, a 'Phrygian cap' on his head and boots. Closing the scene on the right is another Hesperid, also holding an apple in her right hand. The Hesperid in the middle and the one on the right wear a sphendone 
round their hair. The other Hesperid and the youth have long curly hair.

The shoulder has a palmette-decoration on the front and an ivy-decoration on sides and obverse. Below each side handle, a large female head with sphendone. On the obverse, an elaborate palmette-decoration, and on the lower part of the vase runs a wave-pattern decoration.

The hydria has been fully described by Gerhard, Gesammelte Akademische Abhandlungen und Kleine Schriften, I. Band, Berlin, 1866, p. 65 (but was never published before my Noticia ii). It is stated there that such a vase was in Naples in 1825. Gerhard sent a drawing of it to H. Heydemann, who acknowledges it when including the vase among South-Italian representations of the myth of the Hesperides (under letter O. of the list contained in his Berliner Winckelmann Programm, Humoristische Vasenbilder aus Unteritalien, Berlin, 1870). Afterwards it was referred to by F. Brommer in his paper 'Herakles und die Hesperiden auf Vasenbildern', Jahrbuch des Deutschen Archaeologischen Instituts, Band 1vii, 1942, in the list on page 119 in the following way:

'14. Früher Neapel; Hydria: Gerhard a. O. [Ges. Ak. Abh.] 65, 4-Heydemann a. O. [B. W. Pr.].'.

This, the same writer repeats in his Vasenlisten zur griechischer Heldensage, Marburg, 1956, p. 42. 
The hydria therefore was only known to have been at Naples, and further trace of it had been lost.

Now the Palmella hydria is said to have been found in excavations at Herculaneum and Pompei by Dom Manuel and Dom Alexandre de Souza Holstein, at the time they were ambassadors of Portugal at Rome, and the whole collection of vases, which was inherited by their successors, came to Portugal later on, towards the middle of the nineteenth century (1). So that not only does Gerhard's description correspond to our present vase, but there is also perfect coincidence in time, and we may therefore say that the hydria has been found again (2).

As to the interpretation, doubts had already arisen with Gerhard concerning the identification of the youth. As we said above, he only wears a chlamys and a Phrygian cap on his head, cothornoi in his feet and holds a spear in his left hand. Herakles, of course, would be expected to be in the Garden of the Hesperides, but he wears none of the attributes which are usually assigned to him, neither lionskin nor club (3). He does wear them on other red-figured

(1) See above, p. 11-12.

(2) Since the publication of Noticia ii, a second edition of Vasenlisten (Marburg, 1960) has been published, which now includes the hydria on p. 59 under $\mathrm{n} .^{\circ} 14$, with whereabouts as given by us.

(3) A list of the vases representing Herakles in the Garden of the Hesperides has been drawn up several times, first by Gerhard, Abhandlungen, then by H. Heydemann, op. cit., and the most complete one by Brommer, Jahrbuch, later supplemented by himself in Herakles. Die zwölf Taten des 
vases, except perhaps on the vase at the Naples Museum described by Gerhard, Abhandlungen, p. 64, 3 , in the following terms:

'3. Herakles und eine Hesperide; dreihenkliges Gefäss im Museum von Neapel (Neapels Ant. Bildw. I. S. 383). Mittern der Schlangenbaum; die Hesperide, die linkerseits dem Drachen die Schale reicht, hält einen mit einer Binde geschmückten Palmzweig für Herakles bereit, der bekränzt, mit Chlamys und Lanze angetan, in der Linken einen Apfel hält, mit der Rechten aber andere zu pflücken bereit ist. Als bacchisches Attribut ist oberwärts ein Reh, im Hintergrund überdies ein Panther angebracht'.

The vase is a Campanian hydria in Naples 2852, referred to again by Heydemann, Berliner Winckelmann Programm, p. 5 and 7, and Brommer, Jahrbuch, Nr. 3, and Vasenlisten, p. 42, D. 3. It has further been ascribed to the Danaid Painter by Prof. Beazley, 'Groups of Campanian Red-Figure', JHS. 1xiii

Helden in antiker Kunst und Literatur, pp. 94-95, and Vasenlisten zur griechischen Heldensage, pp. 41-42. H. Metzger, Les Représentantions dans la Céramique Attique au IV Siècle, pp. 202-210, deals only with Attic representations, as the title indicates. See also Roscher and Pauly-Wissowa under 'Hesperides'. The above-mentioned attributes started being assigned to Herakles in the early sixth century, apparently under the influence of Stesichorus' poems. On this see C. M. Bowra, Greek Lyric Poetry from Alcman to Simonides, second edition, Oxford at the Clarendon Press, 1961, pp. 123-124. 
(1943), p. 76, n. 3, who is not sure of the youth being Herakles.

I have not been able to see any reproduction of the vase, but it seems that this would be another instance of a youth not clearly identifiable being painted in the Garden of the Hesperides. Examples of confusion in the representation of Herakles are provided by Gerhard, Auserlesene griechische Vasenbilder, Berlin, 1843, p. 169 and Anmerkung 39, p. 171, Anm. 44 and p. 176, and by a late Attic red-figured calyx-krater (1) in the Hoppin Collection, $C V A$. pl. 18, 1-2 and especially by a neck-amphora (2) in Boulogne. Also an amphora

(1) Described ibidem, in the following way:

'The subject is doubtful. The presence of the Silens and the thyrsos would seem to indicate a Bacchic scene so that possibly on one side we may have a bearded Dionysos with a youthful Dionysos on the reverse. The female figure may possibly be Ariadne. The significance of the apple tree cannot be told, since by no possibility can the Garden of the Hesperides (a favourite subject of the Meidian group) with Herakles be recognized'.

(2) Analysed by Prof. Beazley, 'Groups of Mid-Sixth-Century Black-Figure', The Annual of the British School at Athens, xxxii (1931-1932), 15: ' ${ }^{\circ}$ 50. Boulogne. PI. 8. A, Herakles and Amazon. B, maenad and silens dancing. Herakles and an amazon - or so it should be: but actually the 'Herakles' is a replica of the Dionysos on the London vase our n. ${ }^{\circ} 45$, and wears an ivy-wreath like him. The artist must have set out to paint a 'Dionysos and Giant', but having done his Dionysos, forgot that he was not engaged on the commoner subject 'Herakles and Amazon' and proceeded as if he were'. Dietrich von Bothmer, Amazons in Greek Art, p. 72, speaks of 'the faint possibility that the Swing Painter here as so often in his work drew on the large store of lesser-known myths and really intended this picture to be Dionysos and one of the Amazons' and quotes Plutarch, Quaestiones Graecae 56, Pausanias 7.2.7, Tacitus, Annals, 3. 61, and Seneca, Oedipus $479-483$ and also the sculptures at Ephesus. 
published by Inghirami, Mon. Etr. V, pl. XVII; London F 148: a serpent with double head coiled round a tree; Hesperid on left; Herakles without attributes, entirely naked, on right (1).

Now Gerhard, Akademische Abhandlungen, p. 65, thinks of Perseus on his way to the Gorgons, but proceeds to acknowledge that in this case he would be expected to carry a harpe (2) and concludes that this hypothesis would turn out to be as difficult as the Herakles interpretation.

A few vases are known, where the Hesperides are represented in their garden without Herakles at all, although interpretation of them is an open question. These are F I L in Heydemann's list: an Italiote red-figured calyx-krater from Nola in the Naples Museum, n. ${ }^{\circ} 2885$, described by Gerhard, Abhandlungen, pp. 63-64, n. ${ }^{\circ} 1$ (one Hesperid on each side of the tree, the one on the left feeding the serpent; both Hesperides are given names and a third name, not easy to interpret, stands near the tree, on the right) and reproduced by the same on pl. XX, 3 (Brommer, Vasenlisten, p. 42, n. ${ }^{\circ}$ 5); an Apulian

(1) There is also a Boeotian bell-krater, Collignon-Couve $n .{ }^{\circ}$ 1894; Tsountas, 'E $\varphi \eta \mu$. A $\rho \chi ., 1883$, pl. 7a; Campo, / drammi satireschi, p. 167 (pointed out to me by Prof. A. D. Trendall) showing in the centre a tree with fruit and a maenad beside it; to the left is a man in oriental costume and to the right a silen with thyrsos. Prof. Trendall (in a letter) says that the association of the figure in oriental costume with the fruit tree is certainly unusual and may be a satyric version of the legend.

(2) 'Dem Perseus die Harpe zu versagen wäre überdies fast eben so schwierig gewesen als dem Herakles die Keule' (pp. 65-66). 
volute-krater from Ruvo in the Museum of Jatta, published in the Bullettino Archeologico Napolitano, N. S., Anno V, 1857, tav. XII (eleven Hesperides round the tree with the coiled serpent, which is being fed by one of them; some carrying hydriae, and some of them at their toilet), Brommer, Vasenlisten, n. ${ }^{\circ}$; and an Apulian pelike in Catania, Jatta Collection, pl. 90, 768, published by Inghirami, Mon. Etruschi, V, 18 (Libertini, Museo Biscari) (a serpent coiled round a tree, being fed by a woman; a seated woman opening a box; two further women on each side, stretching their arms towards the tree; on a lower level, another woman about to fetch a mirror, and an Eros (1)), Brommer, Vasenlisten, p. 42, n. ${ }^{\circ}$ 10. To these Metzger adds (2) a pelike in the

(1) On Eros in connection with the Garden of the Hesperides see Furtwängler-Reichhold, plate 79.2 (Attic red-figured hydria in the British Museum) and plate 57.2 (Attic red-figured pyxis, also in London). See also Furtwängler, Eros in der Vasenmalerei, München, 1874, p. 38. The myth of the Garden of the Hesperides could be easily associated with love and marriage, since the apples had been a wedding-gift from Ge to Hera on her marriage to Zeus, according to Pherekydes fr. 33 apud schol. Apoll. Rhod. 4.1396.

A tree laden with fruits need not necessarily represent the Garden of the Hesperides: so the lekanis in Leningrad (Furtwängler-Reichhold, pl. 68: bride by the Eleusinian Painter) and a black-figured hydria in Munich $1712 \mathrm{~A}$ by the A. D. Painter (an orchard with women picking fruit; cf. Prof. Beazley, 'Some Inscriptions on Greek Vases', American Journal of Archaeology, lviii (1954), pp. 188-9 and pl. 29). The so-called 'Apple-gatherers' bottle, recently found at Paestum (A. D. Trendall, in Supplement to the Journal of Hellenic Studies lxxvi (1956), p. 57, fig. 10; B. Neutsch in Jahrbuch des Deutschen Archaeologischen Instituts, Archaeologischer Anzeiger, 1xxi (1956), p. 410, Abb. 133) shows an Eros on a tree shaking down fruit which two women collect below.

(2) Op cit., p. 204. 
Hermitage Museum, St. 1788, Brommer p. 42, 17 (b 7).

As to the spring coming from underneath the tree in the above-mentioned volute-krater, it would agree with Euripides' description in Hippolytus, 748-750:

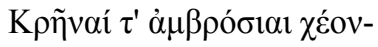

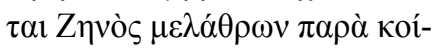 $\tau \alpha 1 \zeta \ldots . . .$.}

There is also question of a spring in Apollonius Rhodius, Argonautica 4. 1411-1460.

The volute-krater in Jatta does not have fruits at all, but only leaves (1). The same absence of apples may be noticed on a fourth-century pelike in New York, 08.258.20, Richter, Red-figured Athenian Vases, pll. 162, 163, 173, quoted by Brommer, Jahrbuch, pp. 117-118.

On the Palmella hydria, on the contrary, great emphasis is laid on abundance of apples. So great that Heydemann (2) took it to be a humorous touch in the representation of the myth, and therefore linked it with Naples 2893 (Ruvo), Gerhard, Tafel 20,1 (where a small panther howls at the serpent) and with Naples 2873 (Paestum), by Asteas. Only three

(1) Some vases formerly included in the list of the Garden of the Hesperides have been set aside afterwards. On this see Brommer, Jahrbuch, p. 106.

(2) Op. cit., p. 8. 
apples were needed, he said, and the painter puts lots of them everywhere (1).

I do not believe that such a humorous touch was intended on our vase, and think that the three apples which, according to literary authorities (2), were supposed to be necessary, need not detain us any more than the variability in the number of the Hesperides which may range from one to eleven.

Now, returning to the question who the youth may be, I think that something may have happened with this vase parallel to the above-mentioned neckamphora in Boulogne. The painter perhaps thought of representing Herakles in the Garden of the Hesperides, and when he came to it made a picture of a youth looking very similar to Jason, who usually wears a chlamys and kothornoi. Jason and the Argonauts were closely associated with the myth of the Garden of the Hesperides, as is proved by the narrative by Apollonius Rhodius, Argonautica, 4.1393-1462, and by the scene on the lower row of the Meidias' vase in the British Museum (though Jason is absent from it (3)).

(1) '..... Soviel Äpfel dass schon ein grosser Kalathos damit gefüllt ist und ausserdem eine Hesperide noch eine grosse Schüssel voll goldener Äpfel bereit hält, während nur drei (vgl. Antiphanes fr. 58 Meineke (3. 33); Apoll. Bibl. 2.5.11.11) Äpfel genügten'.

(2) See above, n. 1.

(3) Inspite of Gerhard's interpretation, Notice sur le vase de Midias au Musée Britannique, Berlin, 1840, reprinted in Kleine Schriften, p. 190.

An association between these two equally famous adventures may be detected in Juvenal 14. 113-114:

certe magis quam si fortunas seruet easdem

Hesperidum serpens aut Ponticus... 
There is no question of assuming that the painter was following here a version akin to the one known to Apollonius Rhodius, since when the Argonauts arrived there the serpent had been killed by Herakles on the previous day. But it may be thought that he somewhat mixed up the two figures and therefore represented as Jason what was to be Herakles, especially as there were vases representing a scene somewhat similar: a tree with a coiled serpent in the middle, Medea on the left and Jason on the right, and other minor figures on each side. Such a scene may be seen on the volute-krater at Naples 3248 (A. D. Trendall, Paestan Pottery, fig. 62, the 'Jason-krater'). All this may have helped to lead to confusion, since at a quick glance both scenes look rather similar (1).

(1) Since the publication of the above interpretation in Noticia ii, pp. 5-13, the hydria has been briefly analysed by Prof. A. D. Trendall, Paestan Addenda, 1959, p. 14. He there states that, although one may be sure about the identification of the Hesperides and the golden apple-tree, the youth in oriental costume can hardly be Herakles. He therefore suggests that he may be Perseus, whom later writers associated with Atlas.

The same interpretation has been advanced by Konrad Schauenburg, Perseus in der Kunst des Altertums, 1960, pp. 88-89. He has no doubts that the maidens are to be identified with the Hesperides, but does not think that the youth is Herakles, inspite of his having also been represented without his usual attributes in the above-mentioned Campanian hydria in Naples 2852, and of the strange features which sometimes turn up on South-Italian vases, like the Berlin lebes F 3196. He thinks the Phrygian cap on the hero's head on our vase a stronger argument for the identification with Perseus than the absence of kibisis, harpe, gorgoneion or winged shoes. His case receives some support from a myth told by Ovid, Met. 4.639 ff., about Atlas having refused hospitality to Perseus, because he feared that an oracle that a son of 
Anyhow, this corresponds to a second stage in the myth of Herakles at the Garden of the Hesperides, as has often been defined (1), when to the primitive struggle and killing of the serpent a pleasant entertainment in the garden has succeeded. This change turns up in the fourth century B.C. and may explain why the serpent is missing in the calyx-krater at the Petit Palais, 327 (P1. XXVII. 3, Metzger) (2).

It is a peaceful scene, drawn in a rather symmetrical arrangement.

This may lead us to the question of authorship of the vase. Prof. Beazley was reminded of the Boston Orestes Painter. Some characteristics assigned

Zeus would rob him of his golden fruits, would be fulfilled, and how as a result of his refusal, he was transformed into a mountain, on seeing Medusa's head.

If this were so, I think the plucking scene would not be as peaceful as the one represented on our vase, so that Gerhard was right when he pointed out that the youth's lack of attributes did not make it easier to identify him with Perseus than with Herakles or some other hero.

(1) So Brommer, Jahrbuch, p. 118; Metzger, pp. 206-208; A. D. Trendall, Paestan Pottery, p. 21. Brommer even says that the picture recalls after-life in the Elysian Fields. The connection of the myth of the Garden of the Hesperides with the belief in a happy survival is asserted by Nilsson, Minoan-Mycenaean Religion, pp. 547-548. I have dealt with this subject in my Concepções Helénicas de Felicidade no Além, de Homero a Platão, Coimbra, 1955, pp. 40-42.

(2) Most literary sources mention it: Sophocles, Track. 1099-1100; Euripides, Her. 394-400; Apollonius Rhodius, 4.1394 seqq. with schol. referring to Pherekydes' version; Pausanias 6.19.8. Some omit it, perhaps owing to their fragmentary condition, like Mimnermus, frg. 10 Diehl, and Sophocles, fr. 297 Nauck; others because it is a reference mostly concerned with other aspects, like Aristophanes, Nubes 271; Euripides, Hippolytus 742-751; Isocrates, Helena 24; Callimachus, Hymni 3. 164. 
to him by Prof. A. D. Trendall (1) are to be found here, namely the expressionless face, tightly-compressed lips and disproportionate length of the lower half of the body and pinched-in waist; also the use of ornaments in his drapery and of a double embattled stripe down the centre of the chiton. Other prominent features pointed out by the same writer, like the watchful look, I cannot see here.

Prof. A. D. Trendall first suggested, by letter, that it might belong to the Asteas-Python Group. I am not able to find most of the characteristics he assigns to Asteas on p. 37 of his Paestan Pottery. And what seems to my mind more decisive than anything else is that Asteas has drawn the same scene with Herakles covered with a lionskin and leaning on his club in the traditional way, in the famous Hesperides lekythos at Naples, 2873, which is signed.

On the other hand, the decoration on the back looks very similar to the one on the squat lekythos recently found at Paestum with the purification of Orestes (A. W. van Buren, American Journal of Archaeology, 1xii (1958), p. 420, pl. 113, figs. 9-10; Journal of Hellenic Studies, Supplement, Ixxviii (1958), p. 37, fig. 12; P. C. Sestieri, Bollettino d'Arte, xliii, 1, (1958), pp. 57-58 and figs. 23, 24,25), as also suggested by Prof. Trendall. There are also two superposed palmettes in the middle, whence smaller patterns irradiate - scrolls and campanula-flowers.

(1) Paestan Pottery, p. 79 and 83. 
Also very similar is the side decoration of the bell-krater in the Vatican Museum AD 1 (Trendall, Vasi antichi dipinti, pl. VII and IXc), which presents the peculiarity of having a white ivy trail running above part of the scene, continued by the usual laurel-wreath. This vase has been assigned to Asteas by Zahn (FR, III, p. 191) but Hauser, FR III, p. 60, n. 2, Watzinger, ibidem, p. 372, n. 2, n. ${ }^{\circ} 15$, and Trendall, Paestan Pottery, p. 62, Vasi antichi dipinti, p. 31, give it to Python.

Since the publication of my Noticia ii, Prof. Trendall has included this hydria in his Paestan Addenda, 1959, p. 14, under number A 204 bis, definitely assigning it to the Boston Orestes Painter. He points out that though the influence of Asteas is to be detected in both the composition and the decoration, the style is different and is much closer to that of such vases as Sydney 48.05, Louvre N 3148 and Naples 946. The heads below the handles he compares with those on hydriai of the Asteas Group like San Simeon, Hearst Estate 5434 or Madrid 11137-8.

Anyhow, the Asteas-Python workshop (1) is closely associated with the Boston Orestes Painter, whom Trendall assumes to have been a late member of that group (2); so that it becomes even more difficult to assign it definitely to any one of them.

(1) On the grounds for speaking of an Asteas-Python workshop see Prof. Beazley, 'A Paestan Vase', American Journal of Archaeology, xlviii (1944), 364, and Prof. Trendall, 'Paestan Pottery: a Revision and a Supplement', Papers of the British School at Rome, XX (1952), 26.

(2) See Prof. Trendall, ibidem, p. 38. 
C A M P A N I A N 


\section{C A L Y X - K R A T E R (PII. LIX-LXI).}

Said to have been brought from Herculaneum and Pompei excavations. Lisbon, Palmella Collection. Notícia ii, pll. 9, 10, 11. Fourth century B.C.

A.

Two warriors, one with a white horse. Both wear an Oscan dress - a short girt with a broad belt - and crested helmets. The two helmets seem to be different; both have two plumes. The warrior on the right, standing near the horse, carries a spear in his left hand and with his right he offers a cantharos to the other man. The warrior on the left also holds a spear in his left hand, and holds a wreath in the right. It looks as if the two warriors were exchanging gifts. The horse behind the warrior on the right has its body facing forwards and head in profile. From the ground below rise saw-like plants, and above hang tendrils and bunches of grapes, half in black and half in white (perhaps ripe and unripe?). A series of dots represents pebbles on the ground, and below it a wave-pattern runs along the vase.

White is used for the horse, helmets, plants, cantharos, wreath, dots and vegetal decoration. 
B.

Draped youth with staff, framed by half-palmettes. He wears a band on his head. On the left an aryballos, and a window above on the right. On the left hang writing-tablets.

This vase is ascribed by Prof. A. D. Trendall, who has seen a photograph of it, to an important subgroup of the AV. style, which he calls the Horseman Group, from the artist's fondness for painting men with horses. He quotes the following as nearest parallels:

(1) Once Hope 299. Tillyard, Hope Vases, pl. 41 .

(2) S. Agata, once Rainone Collection, unpublished.
(A) youth beside horse.
(B) draped youth.

(3) Lost. Illustrated in Millin II 30.
(A) youth beside horse.
(B) draped youth.

(4) Naples 1985 (inv. 82410).
(A) youth with horse in aedicula, on each side of which is a woman with offer- ings.
(B) two draped youths. 
Of these I have been able to see photographs of (1) and (3). (1) represents only one youth holding a horse. He wears the same Oscan costume, and high-strapped sandals and holds a spear, like the warriors on the Palmella vase. But he wears a wreath on his head and holds the horse's bridle. The decoration on the ground and on the upper part is similar, and so is the use of white. The shape is the same: a calyx-krater.

(3) Also represents only one warrior in a similar dress, but with one foot bare; he wears a wreath, not a helmet, on his head; he is holding the horse by the bridle. Everything else is similar to our vase.

Both are so near in style to the Palmella vase that we may easily assume that they have been painted by the same hand.

The shape of the vase, with small, much curled in handles, very high body, is late.

45. B E L L - KRA T E R (PII. LXII and L X I I I ) .

Campanian red-figured bell-krater, said to have been bought in Egypt in 1926 (probably in the market at Alexandria, since no Campanian vase has been found in Egypt). It remained in possession of Mr. Álvaro Costa, Oporto, for many years, and was sold to Dr. Henrique Moutinho, Lisbon, in 1959. Notícia iv, pll. 1, 2, 3. End of fourth century B.C. 
A.

A woman walking with a man, preceded by a satyr and followed by another satyr and a maenad. The man wears a mantle which covers only part of his body and a garland of leaves tied with a band on his head, and carries a kottabos-stand on his left shoulder. The woman wears a chiton and himation, and a radiated fillet on her head and is playing a double-flute. On the right walks a naked satyr, his left arm raised to hold a pointed amphora on his left shoulder, his right hand slightly raised, with outstretched forefinger. On the left, a woman in chiton, wearing a sakkos and a radiated fillet on her head and holding a tympanon in her left hand, to provide musical accompaniment to the flute-player, although she is not playing at the moment, and another satyr, his shoulders covered with a panther-skin, holding a phiale with fruit in his left hand and a burning torch in his right hand. He also wears a radiated fillet on his head. On the upper right part, a window and what seems to be a rosette, looking almost symmetrical to the plastinx of the kottabos-stand. On the lower part, pebbles marking the various levels of the scene. A rock on the right, under the feet of the satyr.

This is no doubt a Dionysiac scene. The women are maenads. The youth in the middle seems to be Dionysos, although it would not be 
easy to explain why he is carrying a kottabos-stand. Instances of Dionysos playing kottabos are known, particularly among South-Italian vases (Cat. Campan. IV D. 862: Dionysos and Herakles (1). Tillyard, Hope Vases, 245, pll. 34 and 32, Apulian situla at Dublin, National Museum: Dionysos with Maenad and Silen. Tillyard, Hope Vases, 230, pl. 32, early Apulian bell-krater in Eton College Museum: Dionysos and Maenad), but he is either reclining on a couch, as befits a symposion entertainment, or sitting.

B.

In the middle, a youth sitting on a rock; round his legs, a himation is loosely draped. The drawing of his head is somewhat damaged, but he seems to wear a radiated fillet on it. He leans his left hand on the rock and holds a phiale in his right hand. On right and left, youths draped in himatia and wearing also radiated fillets on their heads. The youth on the left holds a staff in his right hand. Both of them wear shoes. Two windows are to be seen in the upper part. Behind the youth on the left, something round, not easy to determine.

(1) Quoted by Otto Jahn, 'Kottabos auf Vasenbildern', Philologus, 1867, 206. Whereabouts not stated. 
White is used for heads, necks, arms and feet of the women, for the head-dresses, for the flutes, phialai and fruits, kottabos-stand, amphora, staff, and for the outlines of the panther-skin, windows, rosettes, rock and pebbles. On both sides of the vase, framing palmettes flanked by scrolls ending in campanula flowers.

As to the Campanian group to which this vase may belong, I should assign it to the AV. Group, for the drawing of the heads, with long nose and curved lower lip, the drawing of the chest and elongated fingers, the fierce look, owing to the eye-ball being represented as a vertical stroke, the coarse relief-lines for the folds of the drapery and the wavy line of the bottom. Some of these features are common to other groups as well, but the fierce look and the way of draping the himatia, I find most similar to other vases belonging to the AV. Group, especially CVA. Baltimore, Robinson Collection, fasc. iii IV E, pl. 25, 1 and 2, and CVA. Capua, Museo Campano, fasc. i, IV E r, pl. 24,2 (all neck-amphorae) and Vienna, Oesterreichisches Museum, 471, Pfuhl, Malerei und Zeichnung, fig. 802 (bell-krater). All these vases seem to be by the same hand. To these Prof. Beazley adds a bell-krater in the Vatican (A. D. Trendall, Vasi Antichi Dipinti del Vaticano, fasc. i, U 60, pl. 16) and another one at Manchester (Cambitoglou, 'Some Campanian Vases in Manchester', Memoirs and Proceedings of the Manchester 
Literary and Philosophical Society, xc (1948-1949), plate v, 2 and vi, 1).

Besides other stylistic features mentioned above, both of them have in common the palmette decoration with scrolls and the meander-pattern below, alternating with diagonal crosses. The Vienna krater has the same campanula flowers. On the krater at Vatican U. 60 a ridge painted white on the foot of the vase and the special shape of the same are clearly seen and exactly like our vase.

All this points to the conclusion that we have here another work of the Manchester Painter, as A. Cambitoglou called him(1), and therefore it belongs to a sub-group of the AV. Group which has been outlined by Prof. Beazley in his 'Groups of Campanian Red-Figure', JHS. 1xiii (1943), 76.

So this would now include the following vases, besides ours:

\section{Bell-Kraters}

Vienna, Oest. Museum, 471. A. Pfuhl, fig. 802. A, symposion. B, youth seated and youths.

Manchester Museum. Cambitoglou, Some Campanian Vases in Manchester. A, pl. v, 2. B, pl. vi, 1. A, Herakles and Hippolyte. B, woman between a man and a youth.

Vatican U. 60. Trendall, Vasi antichi dipinti, i,

(1) Op. cit., p. 9. 
p1. XVI. A, warrior's departure. B, woman between two youths.

Winterthur Museum. Bioesch, Antike Kunst in der Schweiz. A, pl. 49. B, fig. 13. A, Bellerophon and King Jobates. B, three youths.

\section{Neck-Amphorae}

Baltimore, Robinson Collection. CVA. III, pl. 25,1. A, woman seated on a tomb, with woman and youth. B, two youths. Restored.

Baltimore, Robinson Collection. CVA. III, pl. 25,2. A, youth with spear and phiale. B, woman with wreath and basket.

Capua, from Capua. CVA. E r, pl. 24,2 and 4-6. A, Nike. B, youth.

A fragment at Oxford, belonging to Prof. Beazley, (a head with a radiated fillet), is certainly by the same hand.

A few other vases very near to these are:

\section{Neck-Amphorae}

Naples, from Caserta. Notizie degli Scavi, 1936, pl. 19, below. A, women at tomb. B, youth and woman. 


\section{Bail-Amphorae}

Naples inv. 147.978, from Frignano Piccolo. A, Notizie degli Scavi, 1937, 119,5. A, woman running with a wreath and basket. B, woman.

Capua, from Capua. CVA. E r, pl. 32, 4 and 6. A, woman. B, youth.

\section{Hydriae}

Capua, from Capua. CVA. IV E r, pl. 15. Youth and woman at tomb.

\section{Skyphos}

New York 06.1021.219. A, woman. B, youth.

\section{Calyx-Krater}

Naples. Patroni, La ceramica antica nell'Italia Meridionale, p. 83, fig. 51. Warrior's departure.

To these Prof. A. D. Trendall adds, op. cit., p. 55, the following vases:

\section{Hydriae}

British Museum, 1949, 9,1.26. Above: Orestes, Pylades and Electra at tomb. Below: thiasos. 
Naples R. C. 54, Mon. Antichi XXII, col. 690, fig. 240. Chariot race. Below the handles: women with cistae.

\section{Oinochoe}

Liverpool M. 10.483. Two men on horseback.

Three further vases included in this list at the time of publication of Vasi Antichi Dipinti, a hydria in the British Museum 1928.1-7.65 - youth in a naiskos and women - and two oinochoai, one at Naples: R C 145-symposion-and one in the British Museum F. 103 - symposion) are now thought by Prof. Trendall not to belong to this painter. As to the hydria, he tells me by letter, he still believes it belongs to the AV. Group, but not to the painter himself; but he assigns the oinochoai to the Nostell Group which is in fact part of the C.A. workshop, though much influenced by the style of the Manchester Painter.

The same scholar further adds the following vases:

\section{Hydriae}

Louvre K 278. A woman and two warriors.

\section{Neck-Amphorae}

Louvre K 292. A, woman pouring libation to horseman. B, two draped youths with spiky head-dresses. 
Trieste 1407 (formerly 855). A, warriors seated between youth and woman. B, two draped youths as above.

Agrigento (ex Giudice 578). A, two warriors and a woman. B, two youths.

As can be gathered from this list, variety in subjects is not a striking feature. The Lisbon krater and the hydria 1949, 9.26, in the British Museum, are the only examples so far known from Dionysiac scenes by the Manchester Painter. 
C U M A E A N 
46. S M A L L A M P H O R A (PL. LXIV).

Small striped amphora, perhaps Cumaean. Said to have been brought from Herculaneum and Pompei excavations. Lisbon, Palmella Collection. Notícia ii, pl. 17.1. Probably fifth century B.C.

As it occurred to many people to use stripes, one cannot assign them definitely to any period. But the shape and the whole of it is like some Hellenistic examples in the Ashmolean Museum, Oxford. Also similar to the one published in Monumenti dei Lincei, 22 , but not exactly the same.

These small amphorae were based on East Greek models and then imitated at Cumae. 
H E L L E N I S T I C 
47.48. SMALL AMPHORAE (PL. LXV. 1, 2).

From Greece. Portuguese Ethnological Museum (The University of Lisbon). Notícia $i$, pl. 5.

The small pointed amphorae must be late but are not easy to date.

49. LACRIMATORIUM (PL. LXVI. 1).

A lacrimatorium or fuseiform unguentarium, or better, a perfume-bottle with stripes. Said to have been brought from Herculaneum and Pompei excavations. Lisbon, Palmella Collection. Notícia ii, pl. 18.1. Hellenistic. 
R O M A N 
50. L A C R I M A T O R I U M (PL. LXVI. 2).

From Greece. Portuguese Ethnological Museum (The University of Lisbon). Notícia i, pl. 5.

This is a lacrimatorium, or rather unguentarium, from the Roman period. 


\section{B I B L I O G R A P H Y}

J. D. Beazley, Attic Black-Figure Vase-Painters. Oxford, at the Clarendon Press, 1956.

J. D. Beazley, Attic Red-Figure Vase-Painters. Oxford, at the Clarendon Press, 1942.

J. D. Beazley, The Development of Attic Black-Figure. Sather Classical Lectures, University of California Press, Berkeley and Los Angeles, 1951.

J. D. Beazley, 'Groups of Mid-Sixth-Century Black-Figure', The Annual of the British School at Athens, xxxii (1931-32), 1-22.

J. D. Beazley, 'The Master of the Dutuit Oenochoe', Journal of Hellenic Studies, xxxiii (1913), 106-110.

J. D. Beazley, 'Groups of Campanian Red-Figure', Journal of Hellenic Studies, lxiii (1943), 66-171.

J. D. Beazley, 'A Paestan Vase', American Journal of Archaeology, xlviii (1944), 357-366.

J. D. Beazley, 'Some Attic Vases in the Cyprus Museum'. From the Proceedings of the British Academy xxxiii, London, 1947.

J. D. Beazley, 'Some Inscriptions on Vases. V.', American Journal of Archaeology, liv (1950), 310-322.

J. D. Beazley, 'Some Inscriptions on Vases. VI.', American Journal of Archaeology, lviii (1954), 187-190.

A. García y Bellido, Los Hallazgos Griegos en Espaha. Madrid, 1936.

A. García y Bellido, Hispania Graeca, Barcelona, 1948, 3 vols.

Otto Benndorf und George Niemann, 'Das Heroon von Gjölbaschi-Trysa'. Sonderdruck aus dem Jahrbuch der Kunsthistorischer Sammlungen des Allerhöchsten Kaiserhauses, Wien, 1889.

HANsJörg Blösch, Antike Kunst in der Schweiz. Erlenbach-Zürich, Eugen Reutsch Verlag. 
HansJörg Blösch, Formen Attischer Schalen von Exekias bis zum Ende des Strengen Stils. Bern, 1940.

Dietrich von Bothmer, Amazons in Greek Art. Oxford Monographs on Classical Archaeology edited by J. D. Beazley and Paul Jacobsthal, Oxford, at the Clarendon Press, 1957.

FranK Brommer, 'Herakles und die Hesperiden auf Vasenbildern', Jahrbuch des Deutschen Archäologischen Instituts, Berlin, 1vii (1942).

Frank Brommer, Herakles. Die zwölf Taten des Helden in antiker Kunst und Literatur. Münster/Köln, Bohlau-Verlag, 1953.

Frank Brommer, Vasenlisten zur griechischen Heldensage. Marburg, N. G. Elwert Verlag. 1. Auflage, 1956. 2. verbesserte und erweiterte Auflage, 1960.

A. W. van Buren, 'News Letter from Rome', American Journal of Archaeology, 1xii, 4 (October 1958), 415-427.

C. Bursian, 'Raub der Leukippiden' Archaeologische Zeitung, x, 40 und 41 (April und Mai 1852), Sp. 433-444.

Alexander Cambitoglou, 'Some Campanian Vases in Manchester' from vol. xc of Memoirs and Proceedings of the Manchester Literary and Philosophical Society, Session 1948-1949, Manchester.

Secondiano Campanari, Bullettino dell'Istituto di Corrispondenza Archeologica, Roma [1854], 234-238.

Émile Cartailhac, Les Âges Préhistoriques de l'Espagne et du Portugal. Paris, 1886.

Conte Di Conestabile, 'Crónica', Boletim d'Architectura e de Archeologia, Lisboa, n. ${ }^{\circ} 12$ (1876), 194.

Corpus Vasorum Antiquorum. Paris and elsewhere, from 1922.

A. A. Mendes Correia in História de Portugal edited by Damião Peres vol. i.

Virgílio Correia, 'Fechos de Cinturão da Necrópole de Alcácer do Sal', Biblos, i (1925), 319-326.

Virgílio Correia, 'Uma Conferência sobre a Necrópole de Alcácer do Sal', Biblos, $i$ (1925), 347-363.

Virgílio Correia, 'Alcácer do Sal. Esboço de uma Monografia', Biblos, vi (1930), 4059.

Virgílio Correia, 'As Fíbulas da Necrópole de Alcácer do Sal', Biblos, vi (1930), 504-509. 
Maria de Lourdes Costa-Arthur, 'Necrópolis de Alcácer-do-Sal (Colección del Prof. Dr. Francisco Gentil)', Crónica del II Congreso Arqueológico Nacional, Madrid, 1951, Cartagena, 1952, pp. 369-380.

V. R. d'A. Desborough, Protogeometric Pottery. Oxford Monographs on Classical Archaeology edited by Sir John Beazley and Paul Jacobsthal, Oxford, at the Clarendon Press, 1952.

Desjardins, Bulletin Monumental, Paris, n. ${ }^{\circ} 5$ [1875], 471-472.

Charles Dugas, 'Tradition Littéraire et Tradition Graphique dans l'Antiquité Classique', L’Antiquité Classique, vi (Avril 1937), 5-26.

FurTwängler, Eros in der Vasenmalerei. München, Theodor Ackermann, 1874.

FurTWängler-ReICHHOLD, Griechische Vasenmalerei. München, 1904-1922.

Arne Furumark, The Mycenaean Pottery. Analysis and Classification. Kungl. Vitterhets Historie och Antikvitets Akademien, Stockholm, 1941.

Édouard Gerhard, Notice sur le Vase de Midias au Musée Britannique. Berlin, De l'Imprimerie de l'Académie Royale des Sciences, 1840.

Édouard Gerhard, Auserlesene Griechische Vasenbilder. Berlin, 1843.

ÉdouARD GERHARD, Antike Bildwerke zum ersten Male bekannt gemacht von... München, Stuttgart und Tübingen, J. G. Cotta'sche Buchhandlung.

Édouard Gerhard, Vases Étrusques et Campaniens du Musée Royal de Berlin. Berlin, chez G. Reimer, 1843.

ÉdouArd Gerhard, Gesammelte Akademische Abhandlungen und Kleine Schriften, I. Band, Berlin, 1866.

W. Gurlitt, 'Sammlung des Hrn. F. Cook zu Montserrat bei Cintra (Lisbon),' Archäologische Zeitung unter Mitwirkung von E. Curtius und C. Friedrichs herausgegeben von E. Hübner. Neue Folge, I. Band (der ganzen Folge 26. Jahrgang), Berlin, 1868, 84-87.

P. Hartwig, 'Die Wiederkehr der Kora auf einem Vasenbilde aus Falerii', Mitteilungen des Kaiserlich Deutschen Archaeologischen Instituts, Römische Abteilung, xii, (Rom, 1897), 89-104.

C. H. E. Haspels, Attic Black-Figured Lekythoi. École Française d'Athènes. Paris, De Boccard, 1936, 2 vols.

H. Heydemann, Humoristische Vasenbilder aus Unteritalien. 30. Programm zum Winckelmannsfest der Archaeologischen Gesellschaft zu Berlin, Berlin, 1870. 
H. Heydemann, 'Due Vasi di Ruvo', Annali dell'Istituto di Corrispondenza Archeologica, lvii (Roma, 1885).

Francesco InghiRami, Monumenti Etruschi o di Etrusco Nome disegnati, incisi, illustrati e pubblicati dal Cavaliere... Tomo V, Poligrafia Fiesolana dai Torchi dell'Autore, 1924.

Отто JAHN, 'II. Griechische Vasenbilder' (Fortsetzung von Nr. 16, S. 270), Archaeologische Zeitung, iii, (Berlin, 1845), Sp. 27-30.

Отто JAHN, 'Kottabos auf Vasenbildern', Philologus xxvi (1867), 201-240.

ERnSt KuHNERT, 'Eine neue Leukippidenvase', Jahrbuch des kaiserlich Deutschen Archaeologischen Instituts, ii (Berlin, 1887), 271-274.

K. A. McDowall, 'Héracles and the Apples of the Hesperides: a new Type', Journal of Hellenic Studies xxv (1905), 157-162.

Henri Metzger, Les Représentations dans la Céramique Attique du IV Siècle. Bibliothèque des Écoles Françaises d'Athènes et de Rome, fasc. 172. Paris, E. de Boccard, 1951.

J. Millingen, Peintures antiques de vases grecs de la Collection de Sir John Coghill Bart. Rome, 1817.

Bernhard Neutsch, 'Archäologische Grabungen und Funde in Unteritalien 1949-1955', Jahrbuch des Deutschen Archäologischen Instituts, Berlin, 1xxi, 3. und 4. Heft, 1956.

Giovanni Patroni, 'La Ceramica Antica nell'Italia Meridionale', Atti della Reale Accademia di Archeologia, Lettere e Belle Arti, Napoli xix, part 2, n. ${ }^{\circ}$ 5, 1897-1898.

Pauly-Wissowa, Real Enzyklopädie der Altertumswissenschaft, s. v. 'Hesperiden', 'Kottabos'.

F. Alves Pereira, 'Novas Figuras de Guerreiros Lusitanos Descritas pelo Dr. L. de Figueiredo Guena', O Archeologo Português, Lisboa, xx (1915), 1-16.

ERnst Pfuhl, Malerei und Zeichnung der Griechen. München, F. Bruckmann A.-G., 1923, 3 vols.

J. DE C. SerRa-RÁfols in Ebert's Reallexikon der Vorgeschichte, s. v. 'Alcácer do Sal'.

Salomon Reinach, Peintures de Vases Antiques recueillies par Millin (1808) et Millingen (1813) publiées et commentées par... Bibliothèque des Monuments Figurés Grecs et Romains, Paris, Firmin-Didot, 1891. 
Salomon Reinach, Répertoire des vases peints grecs et étrusques. Paris, Ernest Leroux Éditeur. Vol. i, 1899. Vol. ii, 1900.

Gisela M. A. Richter, Attic Red-Figured Vases. A Survey. Metropolitan Museum of Art. New Haven, Yale University Press, 1946.

Gisela M. A. Richter and Marjorie J. Milne, Shapes and Names of Athenian Vases. Metropolitan Museum of Art, New York, 1935.

CARL RoBert, Die Marathonsschlacht in der Poikile und weiteres über Polygnot. Achtzehntes Hallisches Winckelmannsprogramm. Mil einer Tafel und zwölf Textabbildungen, Halle a. S., Max Niemeyer 1895 .

Roscher, Ausführliches Lexikon der griechischen und römischen Mythologie. Leipzig, 1884-1894, s. v. 'Hesperides', 'Leukippiden'.

ANDREAS RumpF, Sakonides. Bilder griechischer Vasen herausgegeben von J. D. Beazley und Paul Jacobsthal, Leipzig, Verlag Heinrich Keller, 1937.

Hans SchaAl, Griechische Vasen aus Frankfurter Sammlungen. Frankfurt am Mein, Frankfurter Verlags-Ausstalt A. G., 1923.

Konrad Schauenburg, Perseus in der Kunst des Altertums. Bonn, Rudolf Habelt Verlag, 1960.

P. C. Sestieri, 'Cronaca d'Arte', Bollettino d'Arte, Libreria dello Stato, Anno XLIII, Serie IV, n. ${ }^{\circ}$ 1, Gennaio-Marzo 1958.

FiliPE SimÕes, O Instituto, Coimbra, xxxiii, n. ${ }^{\circ}$ 1-6 [1876], 191-195.

J. DA Silva, Boletim de Architectura e de Archeologia da Real Associação dos Architectos Civis e Archeologos Portugueses, 2." Série, Lisboa, i, 6, [1875], 91-92 and pl. 10.

J. DA SiLVA, Bulletin Monumental, Paris v, [1875], 372.

Cecil H. Sмith, Catalogue of the British and Etruscan Vases in the British Museum, vol. iii, London, 1896.

Frank H. Stubbings, Mycenaean Pottery from the Levant. Cambridge, at the University Press, 1951.

E. M. W. Tillyard, The Hope Vases. Cambridge, at the University Press, 1923.

A. D. Trendall, Paestan Pottery. A Study of the Red-Figured Vases of Paestum. Published by the British School at Rome, 1936. 
A. D. Trendall, 'Paestan Pottery. A Revision and a Supplement', Papers of the British School at Rome, $\mathrm{xx}$ (New Series, vol. vii), London, 1952, 1-53.

A. D. Trendall, 'Paestan Addenda'. Reprinted from the Papers of the British School at Rome, vol. xxvii (New Series, vol. xiv), London, 1959.

A. D. Trendall, Vasi antichi dipinti del Vaticano. Vasi italioti ed etruschi a figure rosse, Monumenti, Musei e Galerie Pontificie. Città del Vaticano, 1953. Fase. i. Vasi proto-italioti, Lucani, Pestani e Campani. Vasi Apuli fino a circa il 375 a.C.

A. D. Trendall, Journal of Hellenic Studies, 1xxi [1951], 183-184.

A. D. Trendall, 'Archaeology in Sicily and Magna Graecia'. Supplement to the Journal of Hellenic Studies, lxxvi (1956).

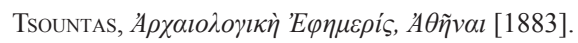

J. Leite de Vasconcelos, 'Notice Sommaire sur le Musée Ethnologique Portugais, Lisbonne', $O$ Archeologo Português, Lisboa, $\chi$, n. $^{\circ}$ 3-5, (1905), 65-71.

J. Leite de Vasconcelos, História do Museu Etnológico Português (1893-1914). Lisboa, Imprensa Nacional, 1915.

J. Leite de VAsconcelos, ‘Acquisições do Museu Etnológico Português', O Archeologo Português, Lisboa, xi (1906), 92; xviii (1913), 163.

Estácio da Veiga, Antiguidades Monumentais do Algarve. Lisboa, 1886, Vol. iv. 


\section{INDEX I}

\section{ANCIENT AUTHORS QUOTED}

AntiPhANES, fr. 58 Meineke (3.33) p. $111 \mathrm{n} .1$ and 2

Apollodorus, Bibl. 2.5.11.11 p. 111 n. 1 and 2

Apollonius Rhodius 4.1393-1462

p. 111,$112 ; 4.1394$ seqq. p. 113

n. $2 ; 4.1396$ p. 109 n. 1 ; 4.14111460 p. 110

ARISTOPHANES, Nubes 271 p. 113

n. 2

Callimachus, Hymni 3.164 p. 113 n. 2

EURIPIDES, Hipp. $742-751$ p. 113 n. 2; 748-750 p. 110

Isocrates, Helena 24 p. 113 n. 2

JuVENAL $14.113-114$ p. 111 n. 3
Mimnermus, fr. 10 Diehl p. 113 n. 2

Ovid, Met. 4.639 seqq. p. 112 n. 1

Pausanias 1.18 .1 p. $69 ; 6.19 .8$ p. $113 \mathrm{n}$. 2; 7.2 .7 p. 107 n. 2

PhereKydes, fr. 33 apud schol. Apoll. Rhod. 4.1394 seqq. p. 109 n. 1, 113 n. 2

PINDAR 69

Plutarch, Quaestiones Graecae 56

p. 107 n. 2

SenECA, Oed. $479-483$ p. 107 n. 2

Sophocles, Trach. 1099-1100 p. 113

n. 2; fr. 297 Nauck p. 113 n. 2

Stesichorus p. 105 n. 3

TACITUS, Annals 3.61 p. 107 n. 2 


\section{INDEX II}

\section{MODERN AUTHORITIES}

(THE NUMBERS REFER TO THE PAGES)

Acosta, Rodríguez, 81

Afonso, A. Martins, 82

BÁrtolo, Maria de Lourdes, 12

Beazley, Sir John, 9, 27, 40, 41, 48, 49, 51 and n. 1, 52, 56, 59, 61 and n. 1, 64, 65 and n. 1, 66 and n. 1, $68,72,79$ n. $1,80,93$ and n. 1, 100, 106, 107 and n. 2, 109 n. $1,113,115$ n. $1,124,125,126$

Bellido, A. García y, 10 n. 1, 73, $75,76,80,81,82,83,84,95$

BenNdorf, OtTo, 67, 68, 69

Bloesch, H., 41, 87 n. 1, 126

Bothmer, Dietrich von, 42 n. 1,107 n. 2

Bowra, C. M., 105 n. 3

Brommer, F., 41 n. 1, 68, 104, 105 n. 2 and 3, 106, 108, 109, 110 and n. 1,113 n. 1

Buren, A. W. van, 114

Bursian, C., 67, 69

Cambitoglou, A., 124, 125 and N. 1

CAMPANARI, S., 42, 43

CAMPO 108 n. 1

Cartailhac, E., 6, 7

CASkey 65 n. 1

Collignon-Couve 108 N. 1

Conte di conestabile 5, 6
Corpus Vasorum Antiquorum 23, 31, $39,48,49,50,55,63,66,76$ n. 1 and $2,80,81,83,88,89,94,95$, 100, 107 and n. 1, 124, 126, 127

Correia, A. A. Mendes, 10 n. 1, 72,73

Correia, Virgílio, 2 and n. 1, 9

Costa-Arthur, M. de L., 2 n. 1, 10 n. $1,77,78,84$ n. 1

Desjardins 5, 73, 74

DE RIDDER 66

EBert 9, 82

FURTWÄNGLER 109 N. 1

Furumark, A., 23 and n. 1, 27 n. 1

Gerhard, E., 42, 43, 44, 104, 105 and n. 3, 106, 107, 108 and n. 2, 110,111 n. 3,112 n. 1

Guigniaut 67

Gurlitt, W., 17, 18, 44, 45, 46, 60, $62,64,65$

Hartwig, P., 68, 72

Haspels, C. H. E., 49, 50, 51 and n. 1, 52 and n. 2, 55

HAuser 115

Heydeman, H., 67, 104, 105 n. 3, 
106, 108, 110 and n. 2, 111 and n. 1

HOORN, VAN, 94, 95

HÜBNER, E., 12, 13, 14, 15, 16, 17 , 93 and n. 2

INGHIRAMI 67, 108, 109

IVANOV 80

$\mathrm{J}_{\mathrm{AHN}}, \mathrm{O} ., 13,14,42,44,64,67,69$, $70,71,123$ n. 1

Kunnert, E., 67

LABORDE 80

LIBERTINI 109

Metzger, H, 105 n. 3, 109 and n. 2, 113 and n. 1

Millin 120

Millingen, J., 67, 69, 71

MiLne 41

Moses 81

Neutsch, B, 109 n. 1

Niemann, G., 67, 68, 69

Nilsson, M. P., 113 n. 1

Oleiro, J. M. Bairrão, 6 n. 1, 12,17

PASSERI 80,81

Patroni 127

Pauly-Wissowa 105 n. 3

Pereira, F. Alves, 8, 74

Peres, Damião, 10 n. 1, 73

Pfuhl 124, 125

RÁfols, J. de C. Serra, 9, 82

ReICHHOLd 109 n. 1
ReINACH, S., 68

Richter, G. M. A., 41, 61 and n. 1, n. 2,63 n. 1,65 n. $2,68,110$

ROBERT, C., 68

RoBINSON 80,81

ROSCHER 68,105 n. 3

RumpF, A., 40

SCHAUENBURG 103,112 n. 1

SCHEFOLd 81,82

SChliemann 1

Sestieri, P. C., 114

SILVA, J. DA, 3, 4, 5, 72, 73 and n. 2,76 and n. 3

SimÕes, FiLipe, 6 n. 1, 17, n. 1, 74, 76,82

Stubbings 23

STUDNICZKa 68

THIERSCH 67, 69

Tillyard, E. M. W., 61, 65,68,69, $71,80,120,123$

Trendall, A. D., 40, 52 n. 1, 94, 103, 108 n. 1, 109 n. 1,112 and n. 1,113 n.l, 114 and n. 1, 115 and n. 1, n. 2, 120, 124, 125, 127, 128

Tsountas 108 n. 1

Vasconcelos, Carolina Michaëlis DE, 73 n. 1

Vasconcelos, J. Leite de, 1 n. 1, 8, 18,19 and n. 1, 82

Veiga, Estácio da, 7, 8

WATZINGER 115

Witte et Lenormant $12 \mathrm{n} .1$

ZAHN 115 


\section{INDEX III}

\section{PAINTERS, GROUPS}

A. D. Painter 109 n. 1

Agrigento Painter 59

Alkimachos Painter 63 and n. 1, 64

Asteas 110, 114, 115

Asteas Group 115

Asteas-Python Group 114, 115 and n. 1

Av. Group 120, 124, 125, 128

Beldam Painter 50, 51 and n. 1 , 52,55

Beldam Workshop 50, 51, 52 and n. 2,55

Black-Thyrsus Painter 80, 81, 82

Boston Orestes Painter 113, 114, 115

C. A. Workshop 128

Coghill Painter 66, 72

Danaid Painter 106

Dutuit Painter 61 and n. 1

Eleusinian Painter 109 n. 1

FAT-RunNer Group 48
Haimon Group 49

Horseman Group 120

Kleophrades Painter 65 n. 1, 79

Leagros Group 41

LeCCE PaInTER 94

Leningrad Painter 59

Manchester Painter 125-129

Meidian Group 107 n. 1

Munich 1842, Painter of, 41

Myson 66

Nostell Group 128

Pan Painter 61

Pig Painter 59, 65 and n. 2, 66

PYTHON 115

SAKONIDES 40

See-saw Painter see Pig Painter

Swing Painter 107 n. 2

Truro Painter 94

Tymbos Group 56 
Greek Vases in Portugal A New Supplement 
When I first published in Hvmanitas (1959: 1820) an Attic black figure hydria belonging to a private collection in Lisbon, the vase already had an adventurous story behind it, and the same happened when I included it in my book Greek Vases in Portugal (1962: 41-47). But now, as I have gathered more information about the vase, I believe it may be appropriate to put together a summary of the previous data, in order to compare them with the results of its having been cleaned by the most expert hands one could wish for.

Formerly a part of Sir Francis Cook's collection, Monserrate Palace, Sintra (Lisbon), the vase is a hydria of Type I, of the last quarter of the sixth century B.C. (Richter-Milne 1935: figs. 78-79). It represents Achilles and Troilos, and a chariot-scene on the shoulder. Unfortunately, the painting had been much restored, so that apparently only the horses on the left had been preserved in their original state. The vase had been included in the Leagros group by Prof. Sir John Beazley (ABV: 362, 36) with the warning ,restored'. By that time, it was considered to be lost. Since the publication of my above mentioned paper, Brommer (1960: 268, 7) included it in the second edition of his Vasenlisten.

Given all this, it might seem that the vase had an academic interest only. But now there are reasons that make it interesting to recollect its curious story up to its present state. 
As far as we now, the vase belonged first to Campanari, then to Rogers, in whose collection it was numbered $372^{1}$, and thirdly to Harding. It was published by Jahn (1845: pl. 2) and by Gerhard (1843: pls. 5 and 6) and also described by Secondiano Campanari (1834: 234-238), who gives a clear interpretation of the scene, taking the figure on the altar as being that of Apollo, whose name he read in the corner.

Although Campanari (1834:238) already spoke of restoration, Gerhard, who knew the vase in apparently the same condition, gives more precise information on the inscriptions, which are important ${ }^{2}$ :

\begin{abstract}
„Das Gefäss ist ergänzt, dargestellt dass, der von Herrn Rogers mir gestatteten Prüfung gemäss, statt der Inschrift $A \Pi O \Lambda \Lambda \Omega N$ füglich TPOIAO $\Sigma$ ursprünglich sein kann; von den übrigen Inschriften, die unangerührt blieben, mag $A X I \Lambda A E Y \Sigma$ beglaubt sein, dagegen wir uns erlauben, die Inschrift ПAPI $\Sigma$, die als Name des Paris jedenfalls $A \lambda \varepsilon \chi \sigma \alpha v \delta \rho o \varsigma$ heissen müsste, bis zur Nachweisung ihrer Echtheit für untergeschoben zu halten. Dieses vorausgesetzt, ist der von Achill auf Apollo's Altar an Troilos verübte Frevel unverkennbar; aus dem skäischen Thor kommt rechterseits Hektor mit später Hülfe herbei, während linkerseits zugleich mit Achill‘s Wagen vielleicht auch Beistand der Griechischen vermutet werden darf."
\end{abstract}

A similar, but more accurate, description has been provided by Gurlitt (1868: 86), when he saw the same vase at Monserrate palace. Here I only give a transcription of its most relevant parts:

„Zunächst die Vordertheile von vier Pferden mit weissem Zaumwerk. Es folgt eine grosse Kriegergestalt, welche durch eine Inschrift links vom Kopfe als AXIAAEY bezeichnet

\footnotetext{
${ }^{1}$ It has been described in the sale catalogue of the Samuel Rogers' Collection, Christie and Manson, April 28th 1856 ff., p. 25 (I owe this reference to Dr. Dietrich von Bothmer).

${ }^{2}$ In this as well as in the following inscriptions, archaic Greek letters have been replaced by classic ones, owing to printing difficulties.
} 
ist. Auf dem Kopfe, von dem reiche Locken auf die rechte Schulter herabwellen, trägt er einen grosser Helm mit grossem, braunem Kamm und langem Helmschweif, der Brustharnisch ist weiss, ebenso die braugeränderten Beinschienen. Der linke Fuss tritt in starker Biegung auf einen Mauerabsatz, welcher aus zwei Lagen Quadersteinen gebildet ist. Seine hochgehobene Linke hat die Rechte eines nackten Knaben von sehr gefälliger Bildung erfasst, welcher noch höher auf einer zweiten Stufe dieses Absatzes steht und reisst sie in die Höhe über den Kopf des Knaben hinaus. Die Rechte zückt ein langes Messer gegen ihn. Auch dieser Knabe, dessen Linke flehend in die Höhe gerichtet ist, ist durch eine Beischrift näher bezeichnet. Am linken Arm des Achilleus entlang steht etwas undeutlich, aber doch unzweifelhaft der Name MAPI . Rechts von diesem Mauerabsatz, der hinten gerade abschliesst, ist die Hälfte eines gerüsteten Kriegers mit Helm, Schild und Lanze sichtbar. Es folgt ein Pfeiler, unten weiss, oben schwarz, welcher durch die ganze Hobe des Streifens hindurchgeht und ihn in zwei Theile theilt. Rechts von denselben zeigen sich wieder die Vordertheile eines Viergespanns, dann ein Krieger in vollständiger Rüstung. Darüber sehen von einer zinnengekrönten Mauer ein behelmter und ein unbehelmter Kopf herab, letzterer auffalend roh.“

When I saw the vase (Figs. X and XI), which at the time belonged to a private owner in Estoril (Lisbon), only one of the three above mentioned inscriptions had been preserved, namely the one reading $A X I \Lambda \Lambda E Y \Sigma$, obviously referring to the warrior between the horses and the altar.

Troilos only showed his left arm, so that Achilles' gesture had no point. The spear of the warrior behind the altar had been repainted - so that it was quite upright - , as had the column in the middle. There was a horse's head on the shelf on the right, which was new and made no sense. The chariot-scene on the shoulder had been left untouched.

The second restoration also showed several layers of painting, which have badly damaged the drawing. 
And here begins the second part of the story. Two years after the publication of GVP, in April 1964, Dr. Dietrich von Bothmer, the then chairman of the Department of Greek and Roman Art of the Metropolitan Museum of Art in New York, and, as everyone knows, one of the most outstanding authorities in the field, spent a few days in Lisbon in order to be able to see the Greek vases he knew through my publications. Most of all, he wanted to clean the hydria of the Leagros Group. This he did, with the consent of the owner, but it took a long time until I managed to get good pictures of the vase, taken by a professional photographer, and to send them to him in New York.

I think it is worth quoting a few lines of his reply, dated February $7,1966^{3}$ :

"You must admit that there is quite a difference between the old restoration and its real condition. I am very glad to have the record of my labors.»

As a matter of fact, now we can see (Figs. XI-A and XI-B) how badly damaged Troilos' figure was, and also that what stood on the shelf on the right was just another helmet (not the head of a horse, which made no sense, as I said above).

At closer inspection, other details emerge, such as that the altar of Apollo is made of black tiles only; that only the lower part of Troilos' body has been preserved; that Achilles' corslet was not painted white, but only had incised lines, as usual; that the column with drawings to the right of the altar was a representation of the walls of Troy; and that the shields of the warriors coming to the rescue of the boy had no devices on them.

\footnotetext{
${ }^{3}$ The cleaning of the vase is duly registered in Beazley, Para, p. 161.
} 
Although the Iliad makes only one mention of Troilos (24.257), as being one of the sons Priam lost during the Trojan war, other ancient epics, like the Cypria, already specified that he was killed by Achilles. Leaving aside other details of the story (which later became also the subject of a lost tragedy of Sophocles), other ancient sources added that the incident happened on the altar of the sanctuary of Apollo Thymbraios, in the Trojan plain.

To demonstrate how popular the myth became, it should be enough to count the number of vases listed by A. Kossetz-Deissmann in LIMC I, 1. 72-95 under the heading "Das Troilusabenteuer", totalling one hundred and fifty-four. Of these, fourteen are concerned with our present subject: the killing of Troilos and the subsequent struggle for his corpse.

Now, out of these examples, only the Lisbon hydria (which is mentioned there under number 362) seems to show Troilos while still alive. The other ones show the struggle for his corpse. That is what can be seen on all the other vases in Attic black figure style: Achilles holding Troilos' head in his left hand, in order to throw it to the Trojan opponents who are coming to rescue the boy. Killing someone within the precinct of a temple was liable to be punished by the gods, as was to happen later.

Nevertheless, examples of Troilos taking refuge on Apollo's altar turn up in other styles, for instance in an Attic red figure cup in Perugia by Onesimus (n. ${ }^{\circ}$ 370 in the LIMC catalogue): the boy tries to climb up to the god's altar, but Achilles has already grasped Troilos' hair with his left hand.

More or less contemporaneous with the Lisbon hydria, there is another hydria in the British Museum, 
also ascribed to the Leagros group, and dated to c. 510 B.C. The general scheme is the same, that is to say, an altar in the middle, Achilles' quadriga on the left and Troian warriors on the right. But here another moment is depicted: Achilles has already killed Troilos, whose corpse is falling on the altar, and he holds the boy's head in his right hand, threatening to throw it at his opponents.

Returning to the Lisbon hydria, we feel sure that here Troilos is still alive, since he is standing on the altar. It seems that Achilles' raised left arm, which seems to reach the circle round the shoulder of the vase, has not yet grasped the boy's hair.

More instances of this part of the story may, of course, turn up at any moment, but the examples quoted above show well enough how popular this part of Troilos' fate had become. This in spite of its absence from the Homeric tradition, which only gives to the young son of Priam the epithet i $\pi \pi \imath \chi \alpha \alpha \rho \mu \eta \varsigma$ ('a warrior who fights from a chariot').

\section{Abbreviations}

Beazley, $A B V$

Beazley, Para

Brommer

Campanari

Gerhard

Gurlitt
Attic Black-Figure Vase-Painters

(Oxford 1959)

Paralipomena (Oxford 1971)

Vasenlisten zurgriechischen Heldensage (Marburg ${ }^{2} 1960,{ }^{3} 1973$ )

Bullettino dell'Istituto di

Corrispondenza Archeologica (1834, 234-238)

Vases étrusques et campaniens du Musée Royal de Berlin (1843)

Archaeologische Zeitung (N. F., I, 1868, 84-87) 
Jahn

$L I M C$

Richter-Milne

Rocha Pereira

"Griechische Vasenbilder", Archaeologische Zeitung (III,1854) Lexicon Iconographicum Mythologiae Classicae (Zürich und München I, 1, 1981)

Shapes and Names of Athenian Vases (New York, The Metropolitan Museum of Art, 1935)

"Notícia sobre vasos gregos existentes em Portugal. II. ${ }^{a}$ Parte", Humanitas (XI-XII, 1959, 18-20)

Rocha Pereira, GVP Greek Vases in Portugal (Coimbra 1962) 
PLATES 

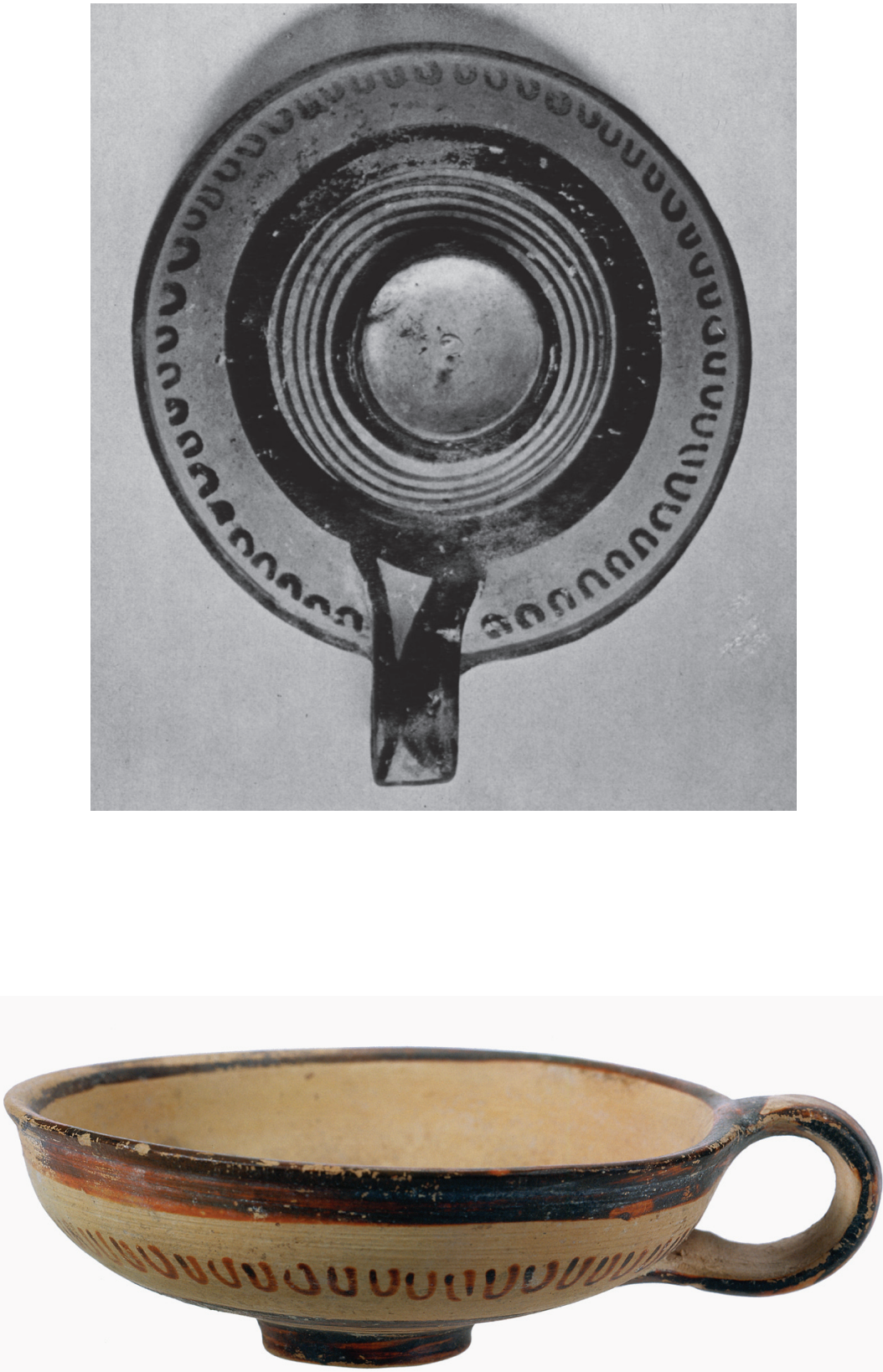


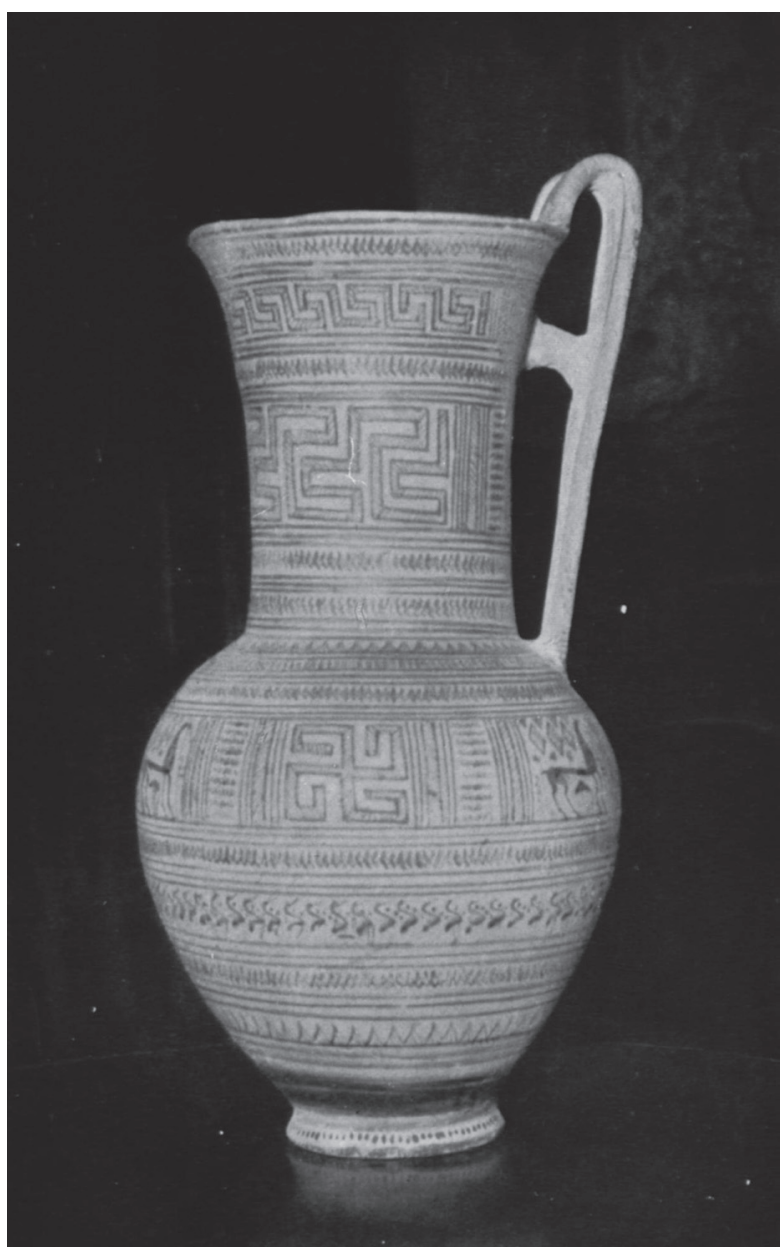



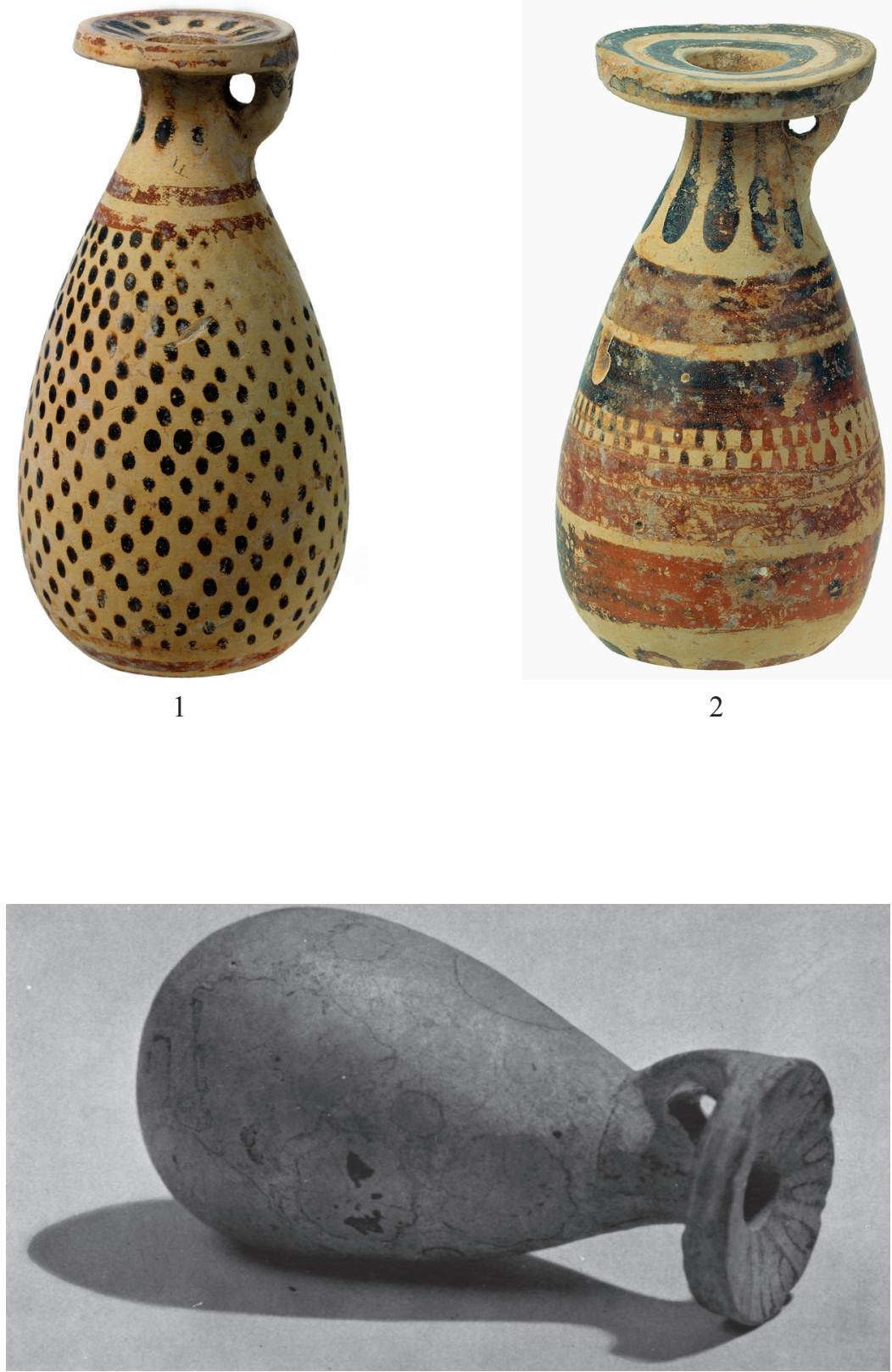


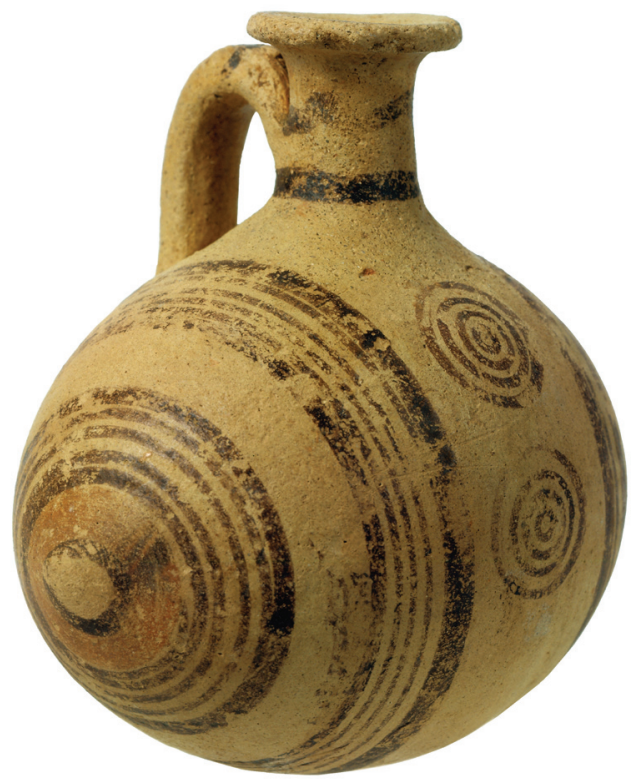




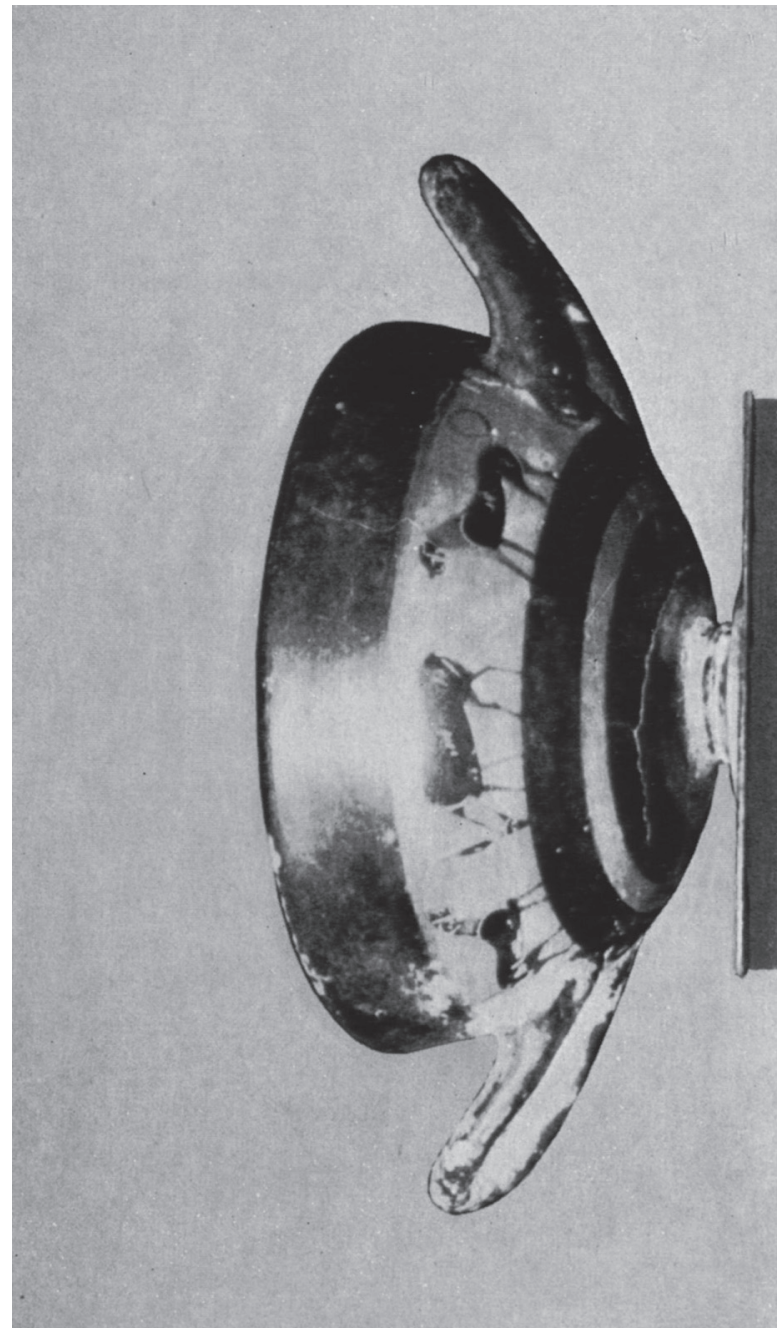




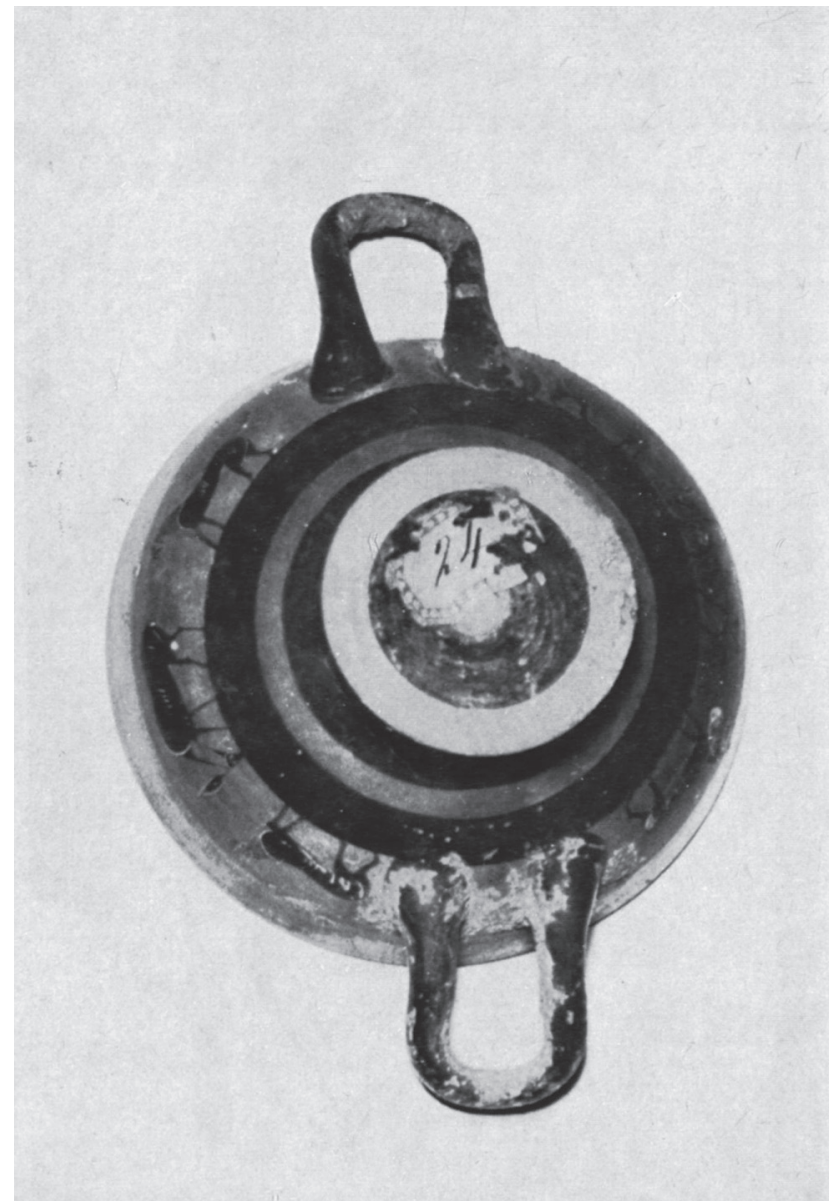




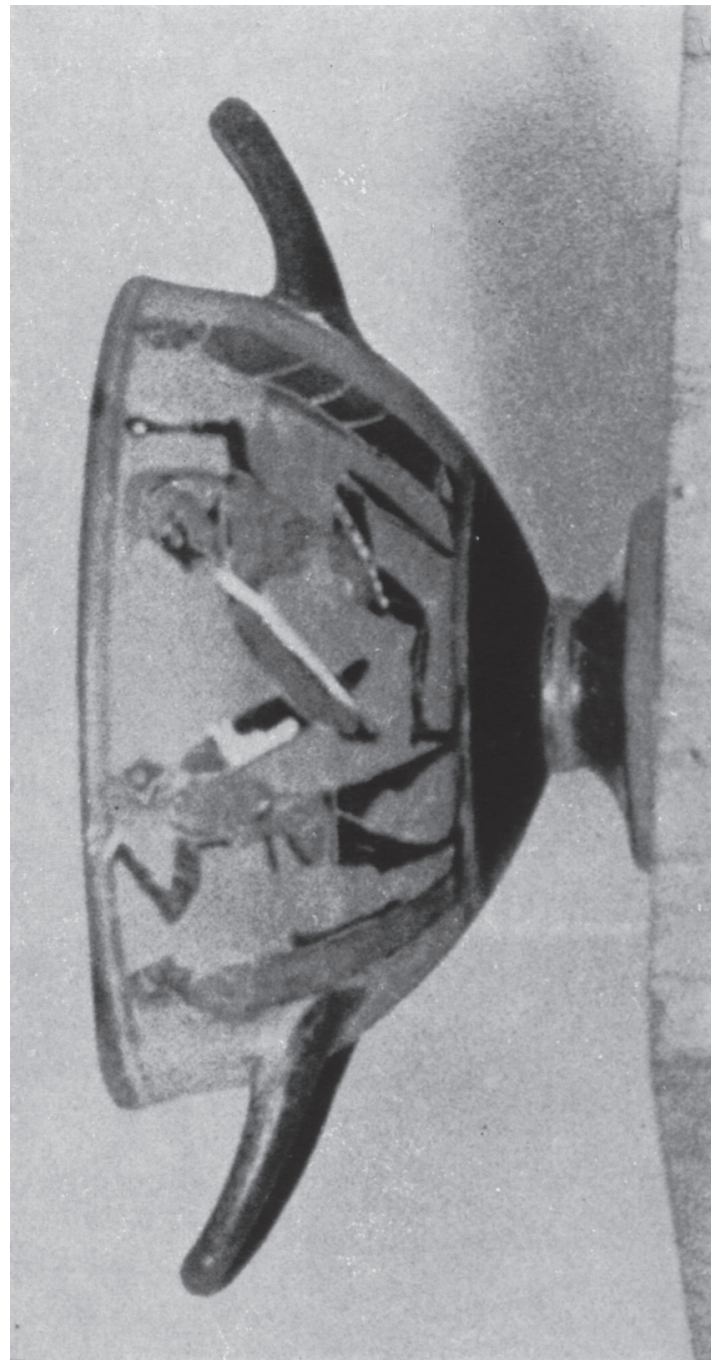





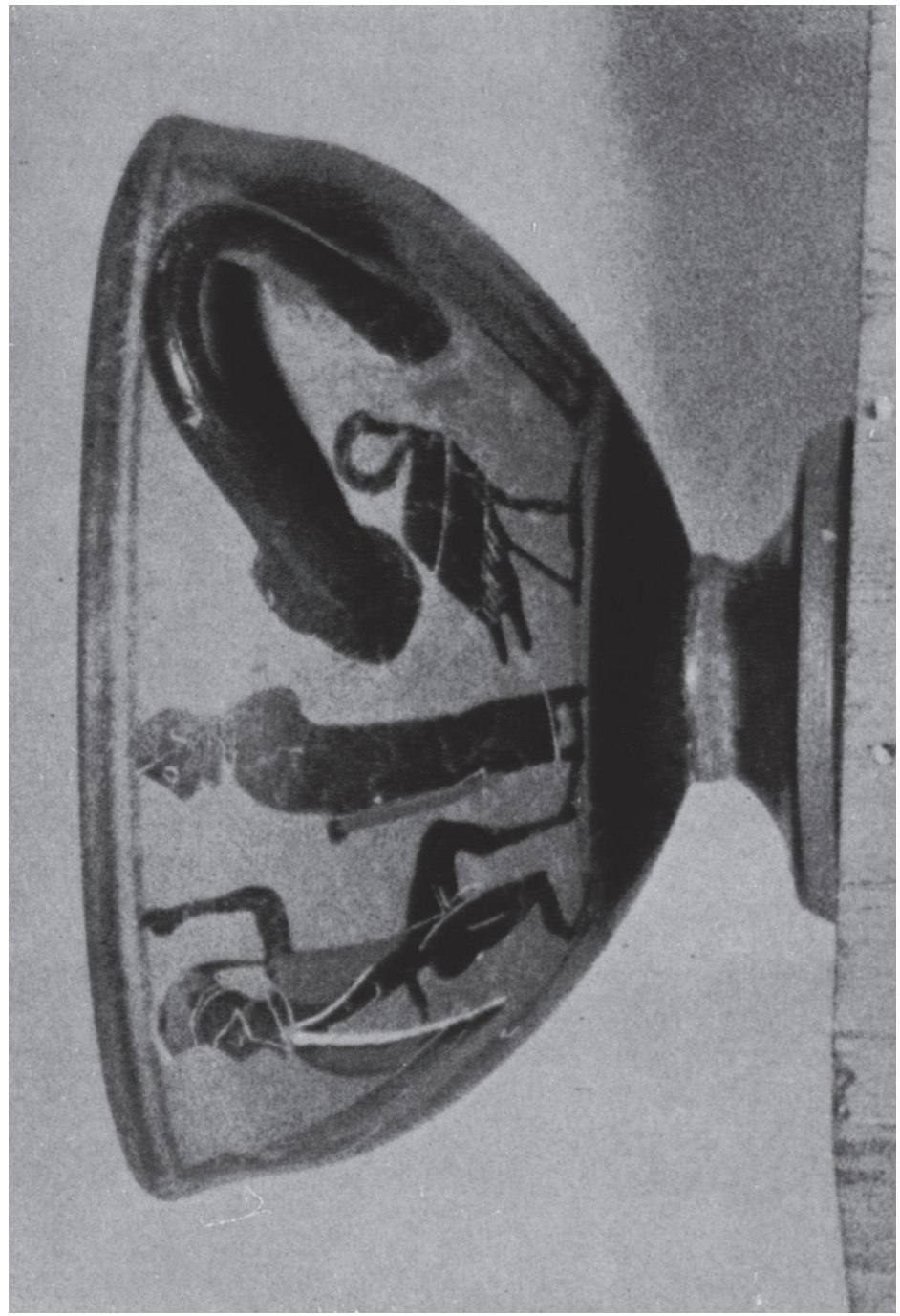




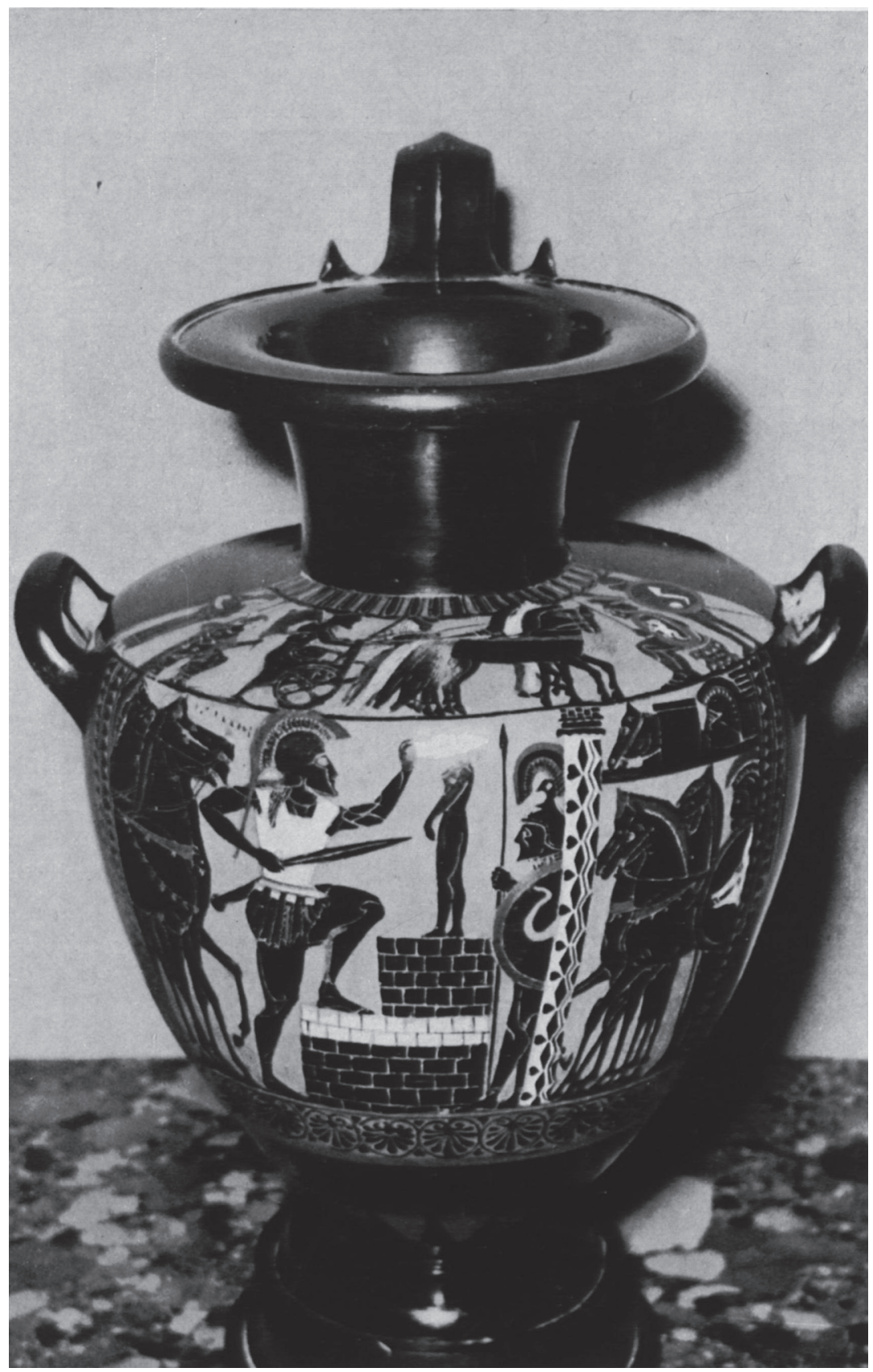




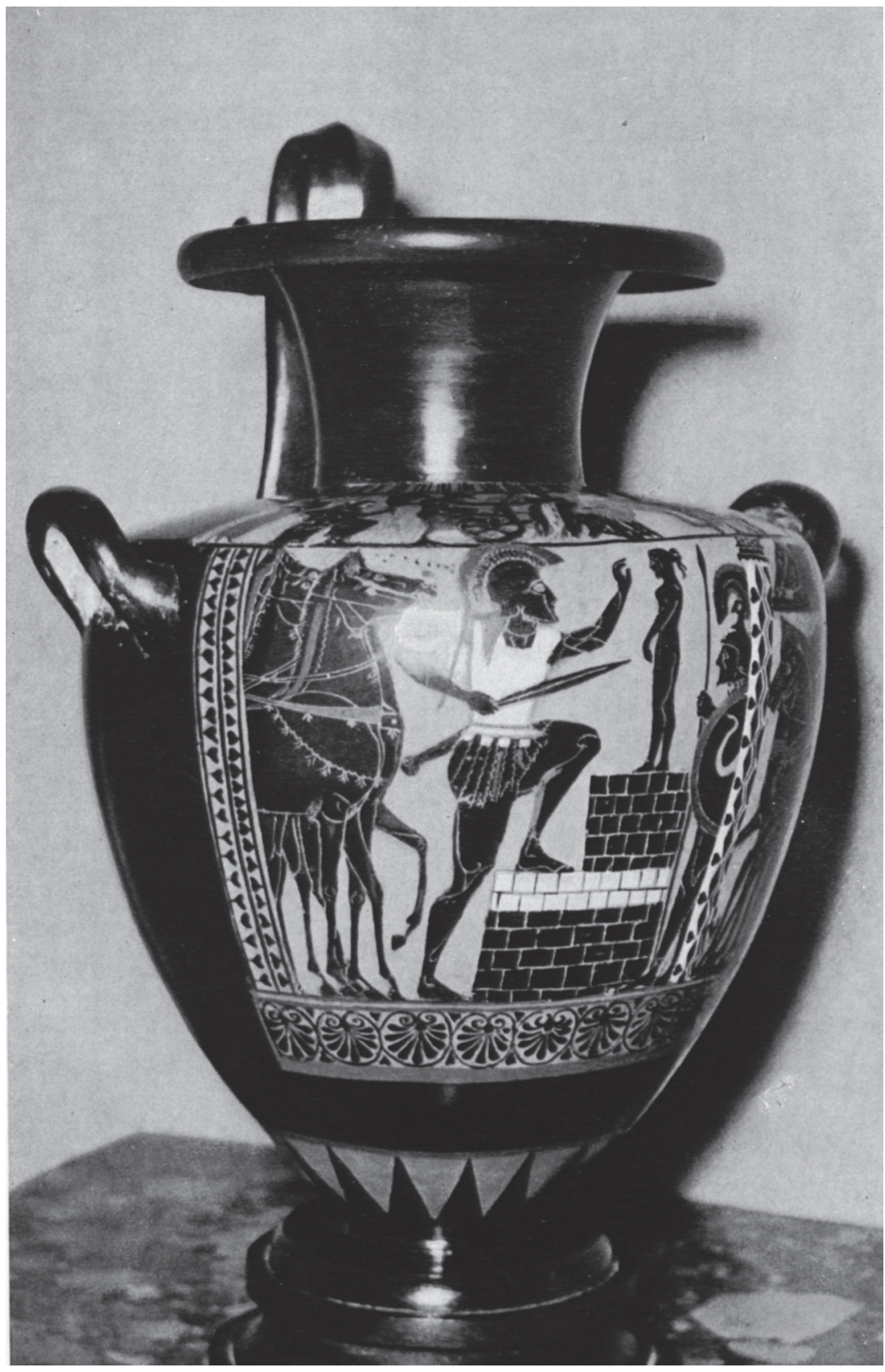


XI-A

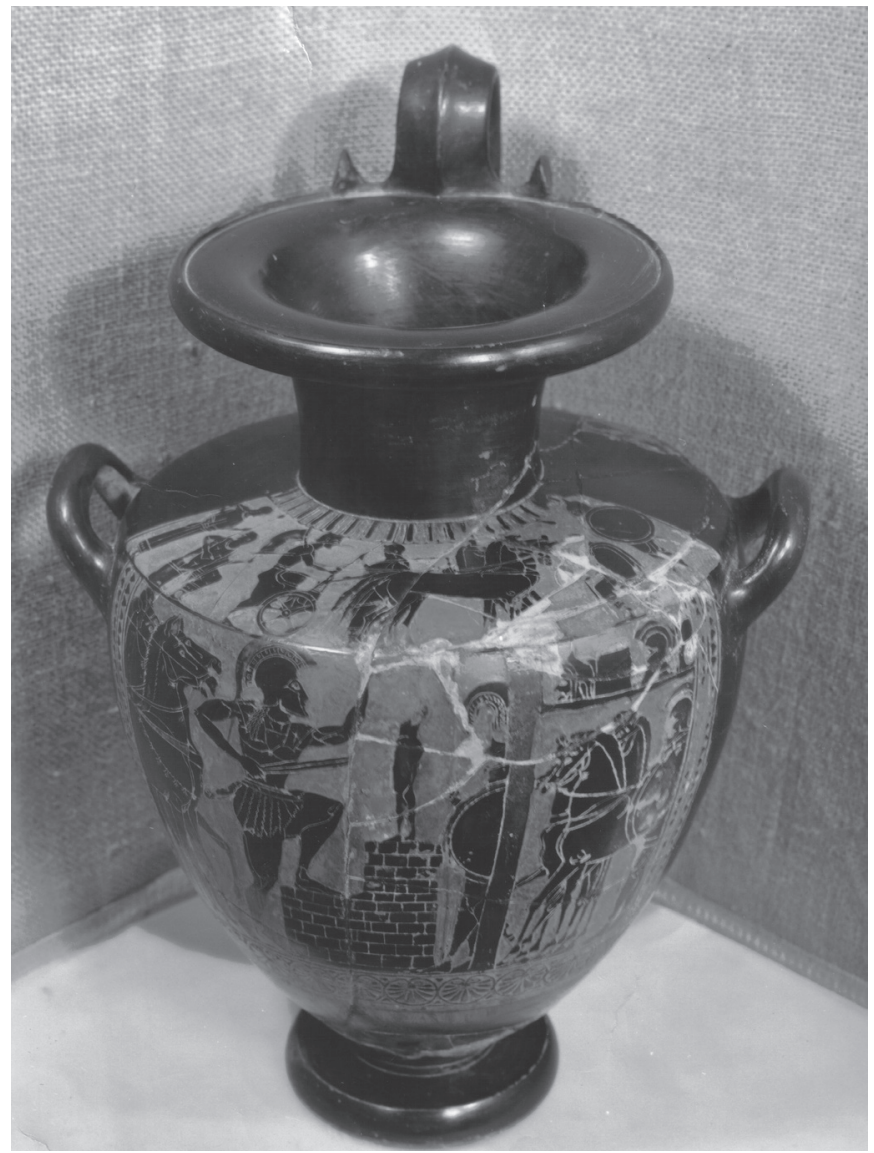


XI-B

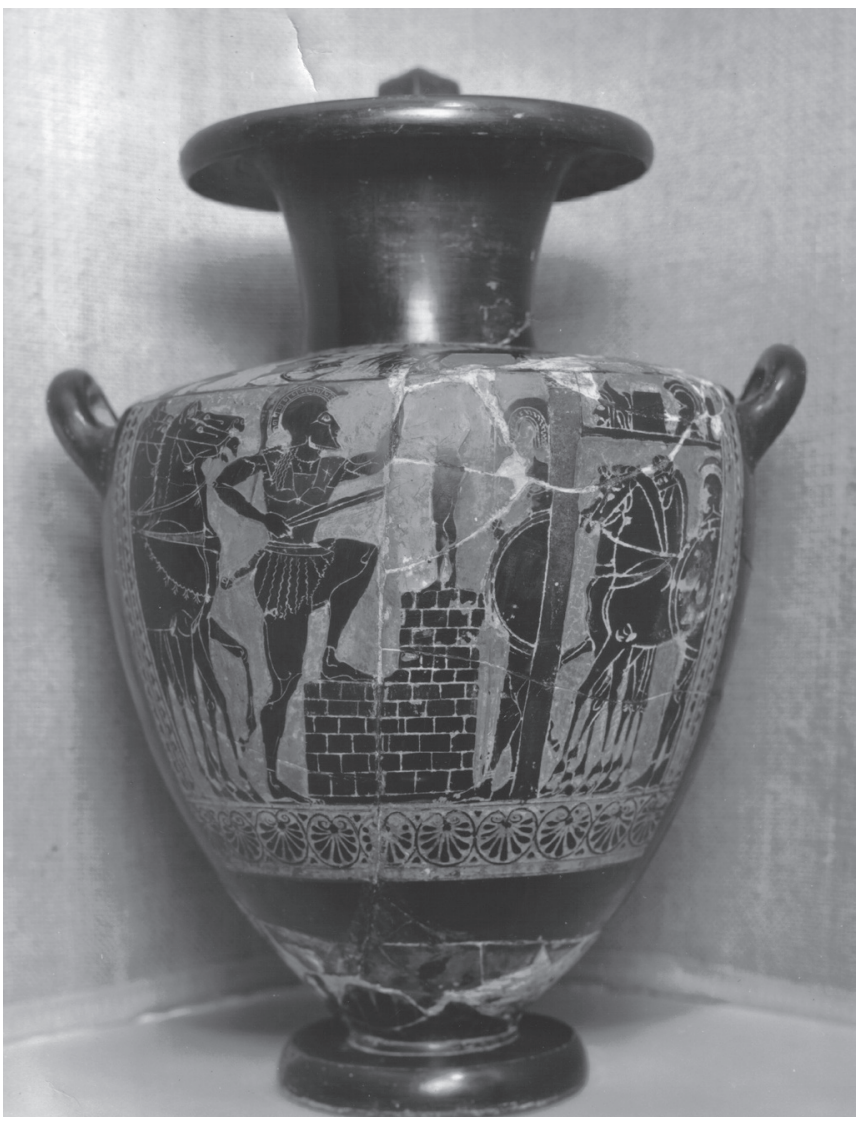




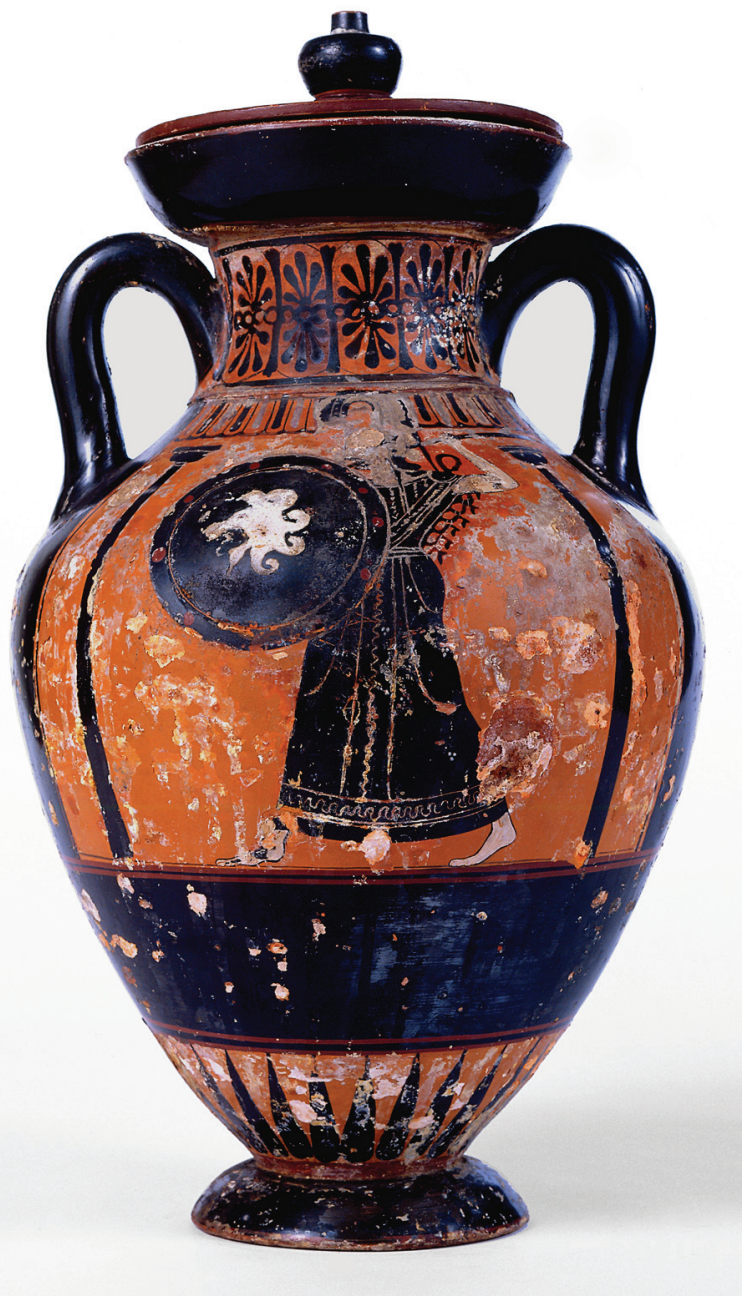




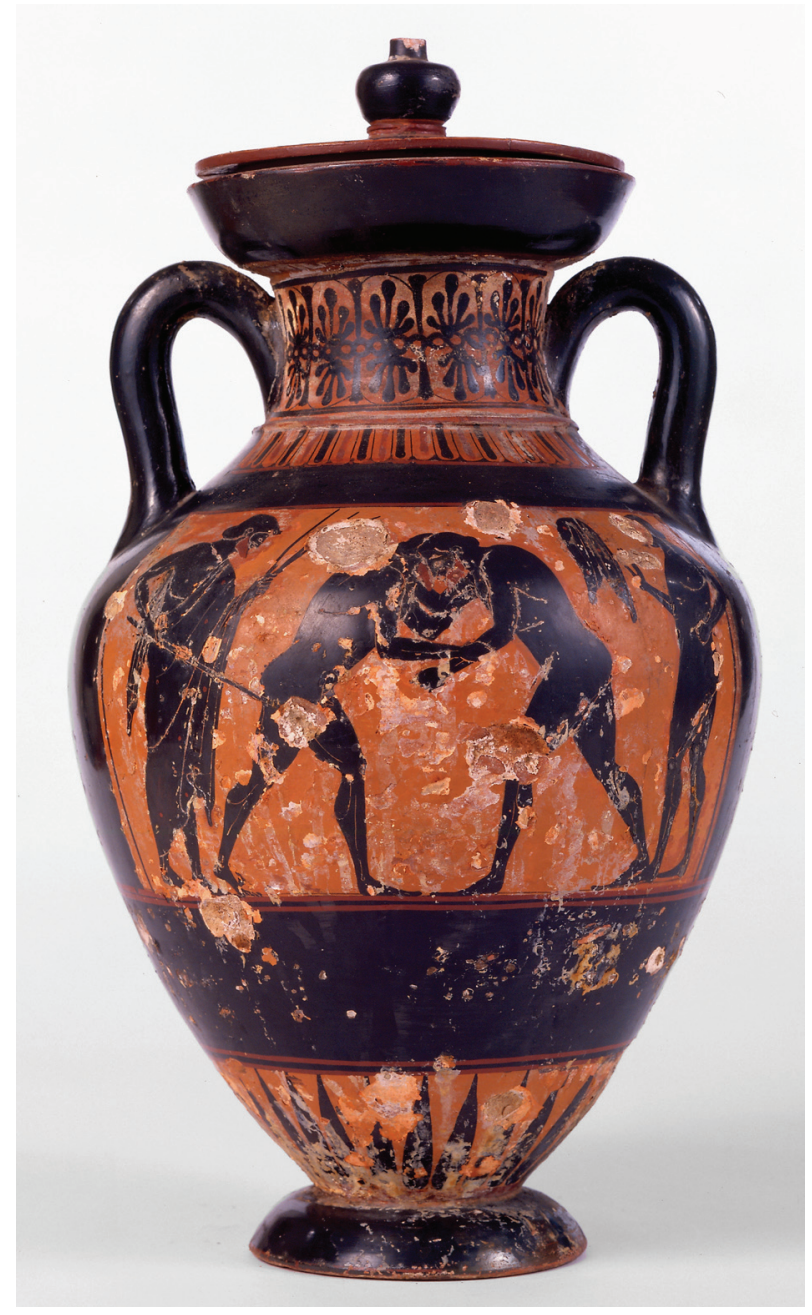




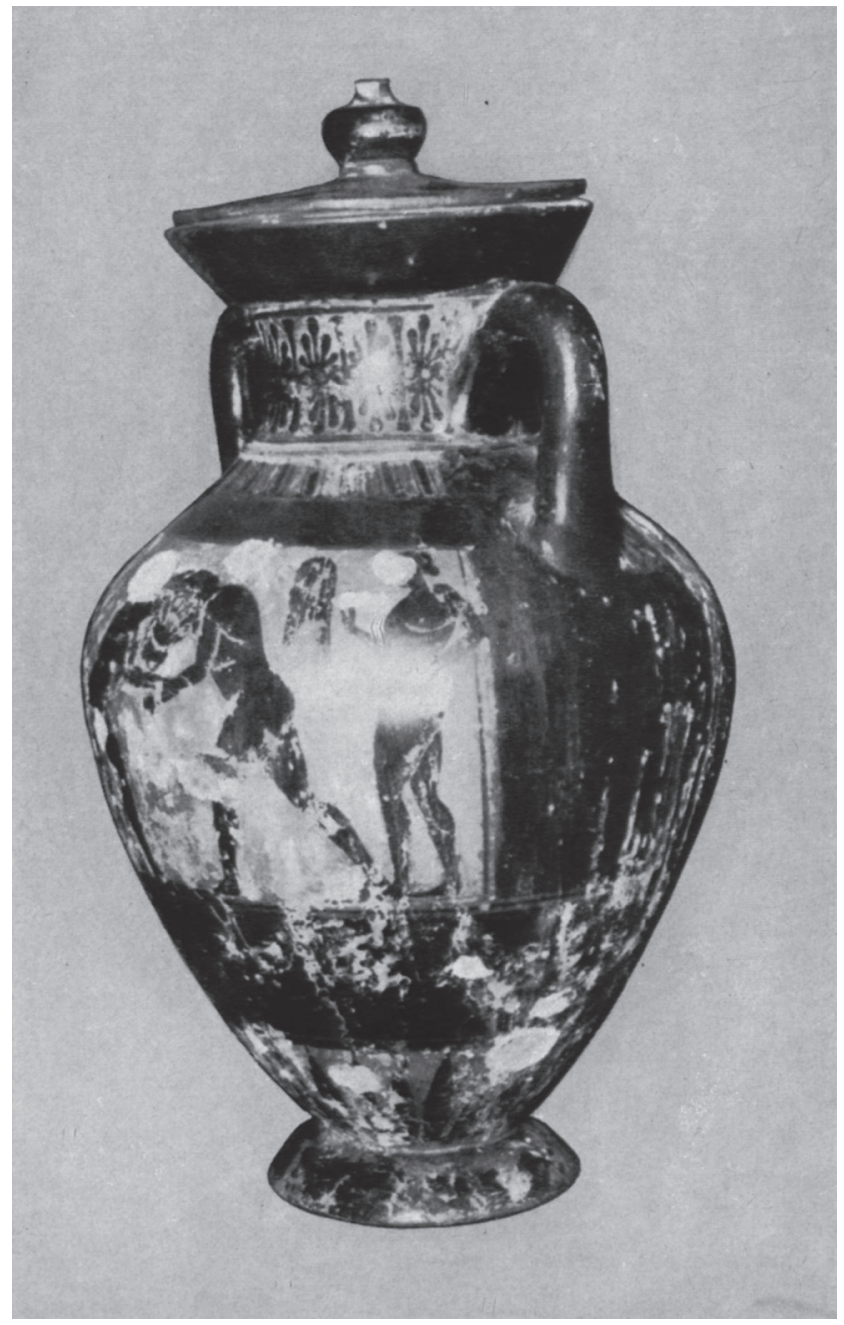



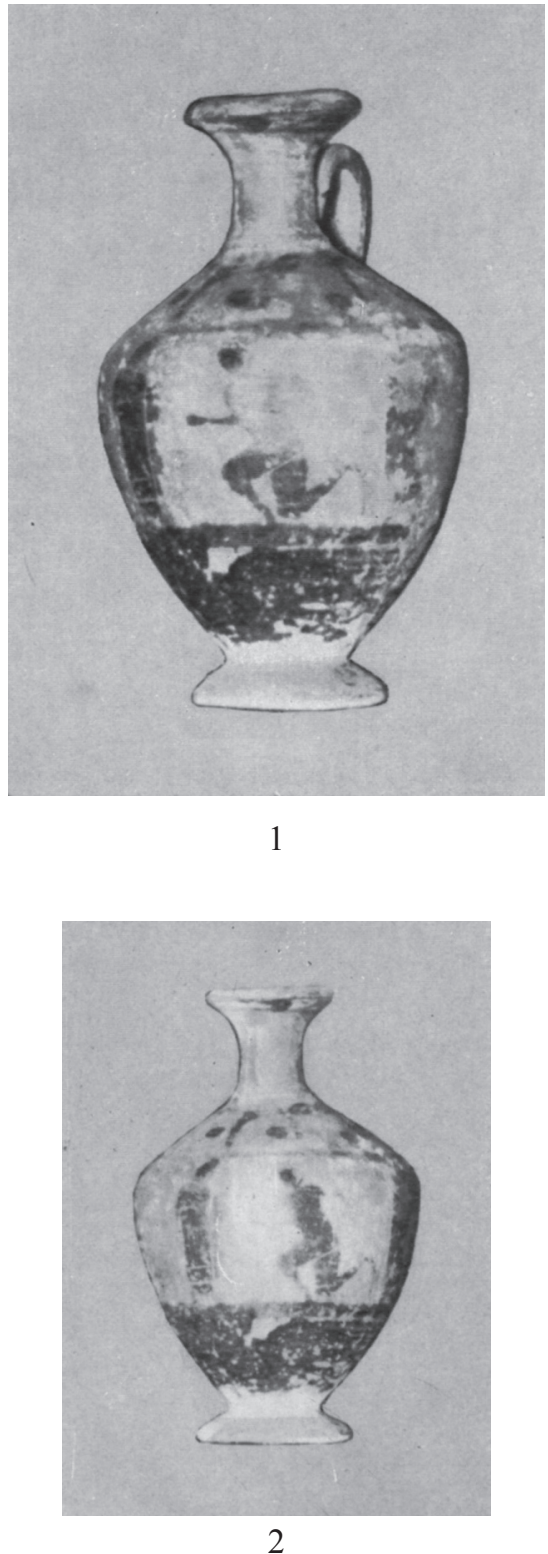
XVI

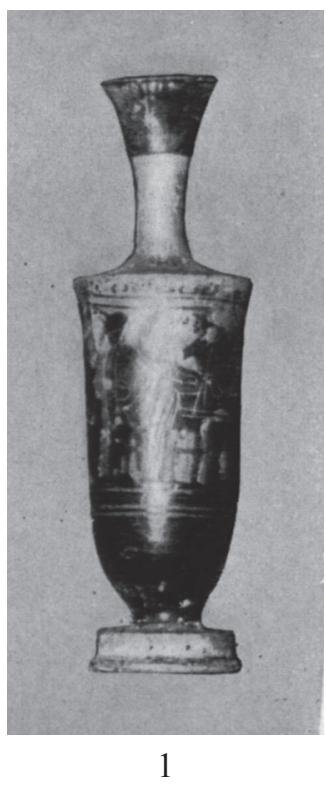

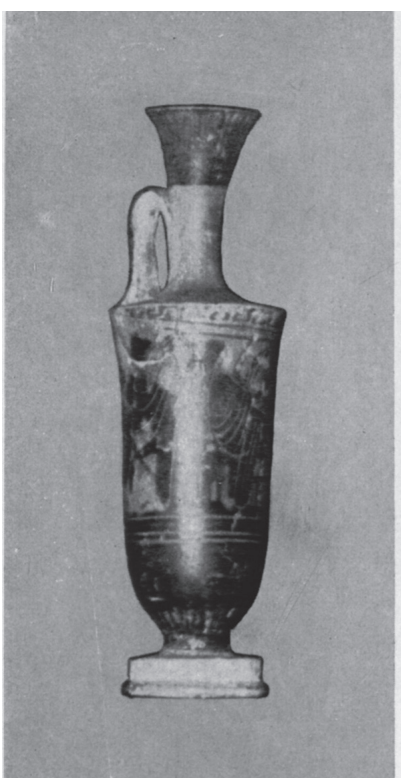

2

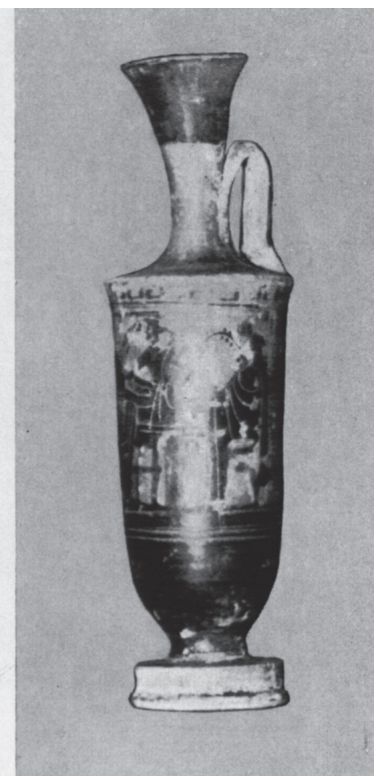

3 
XVII
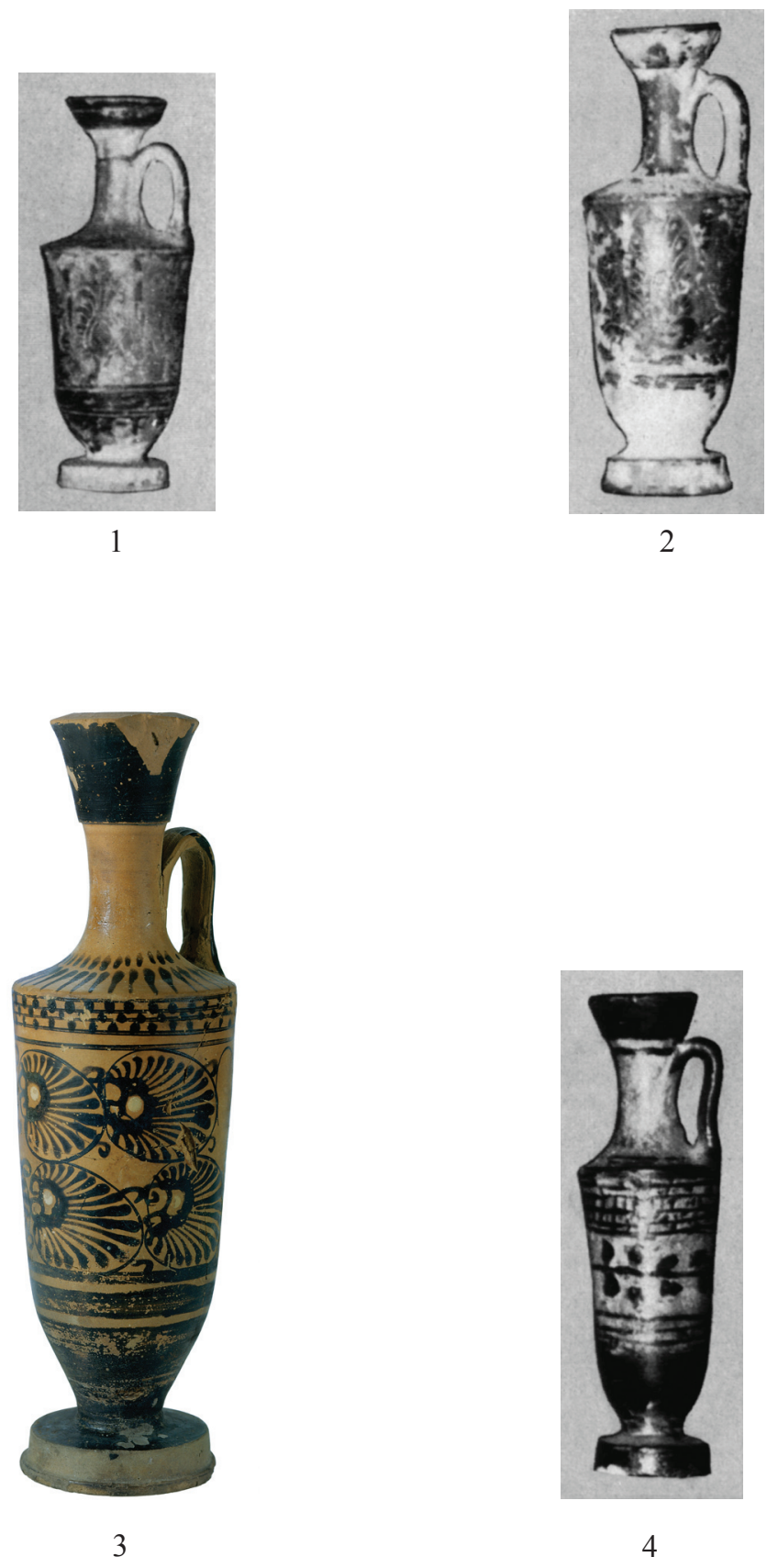

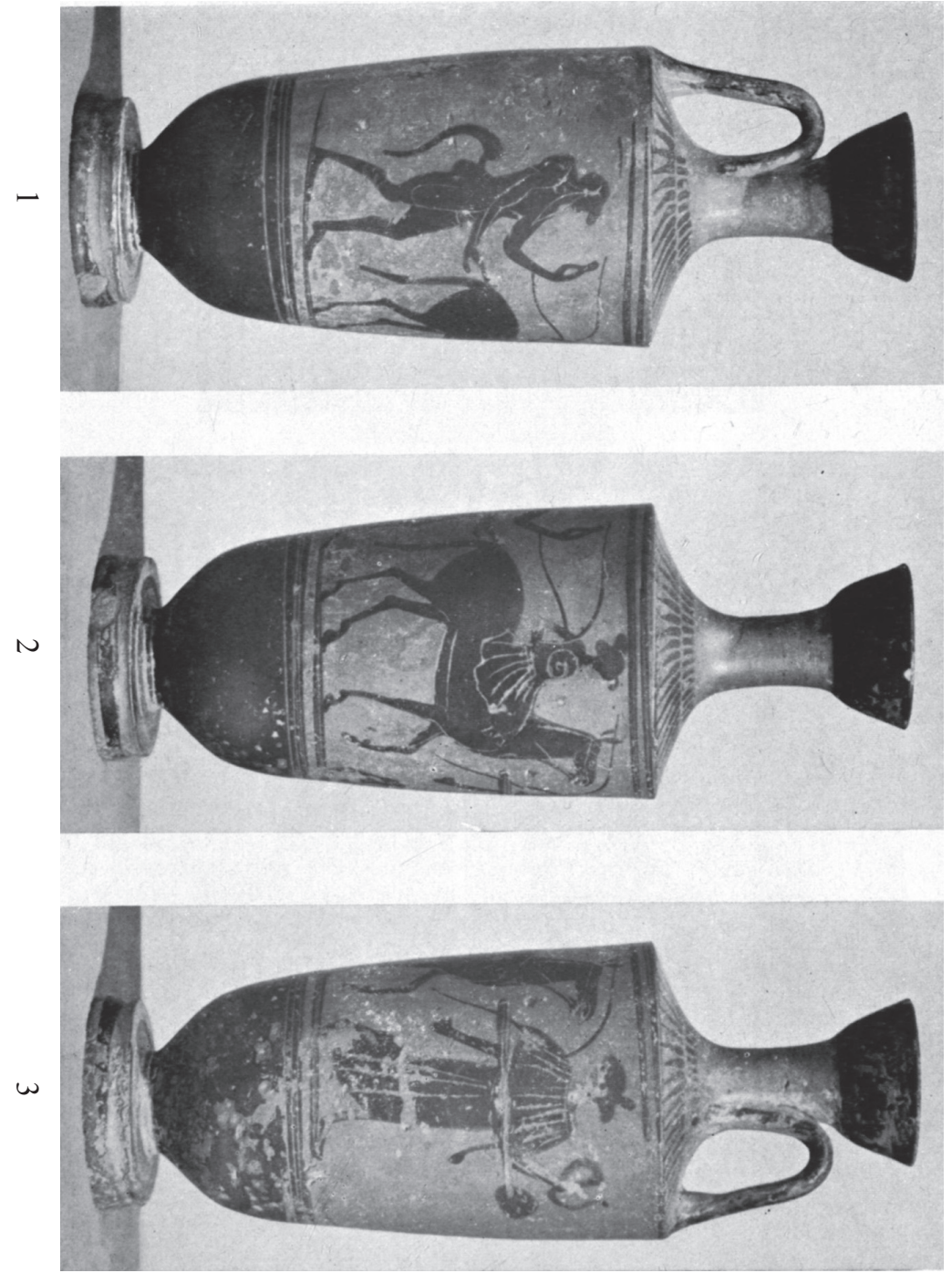

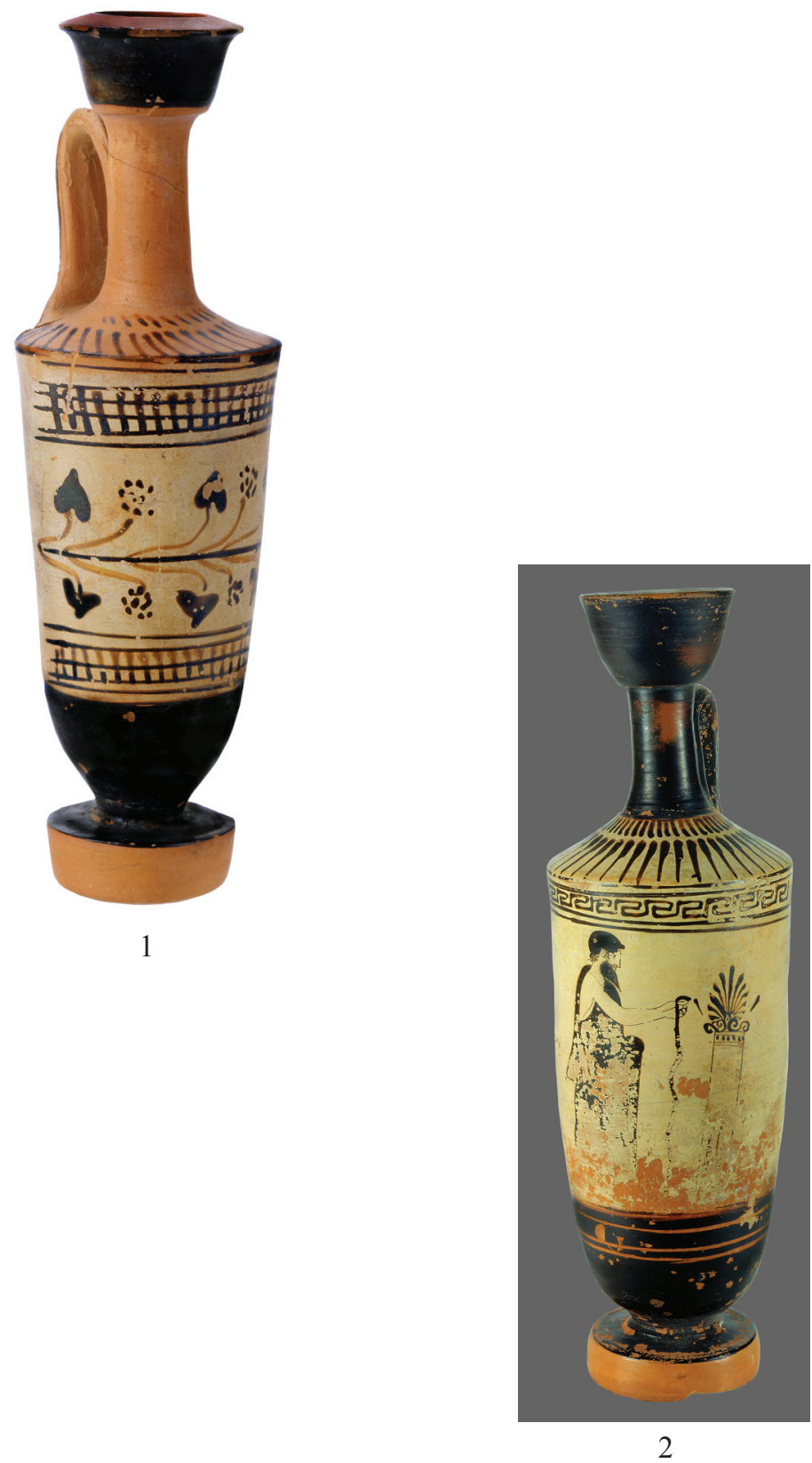
XX
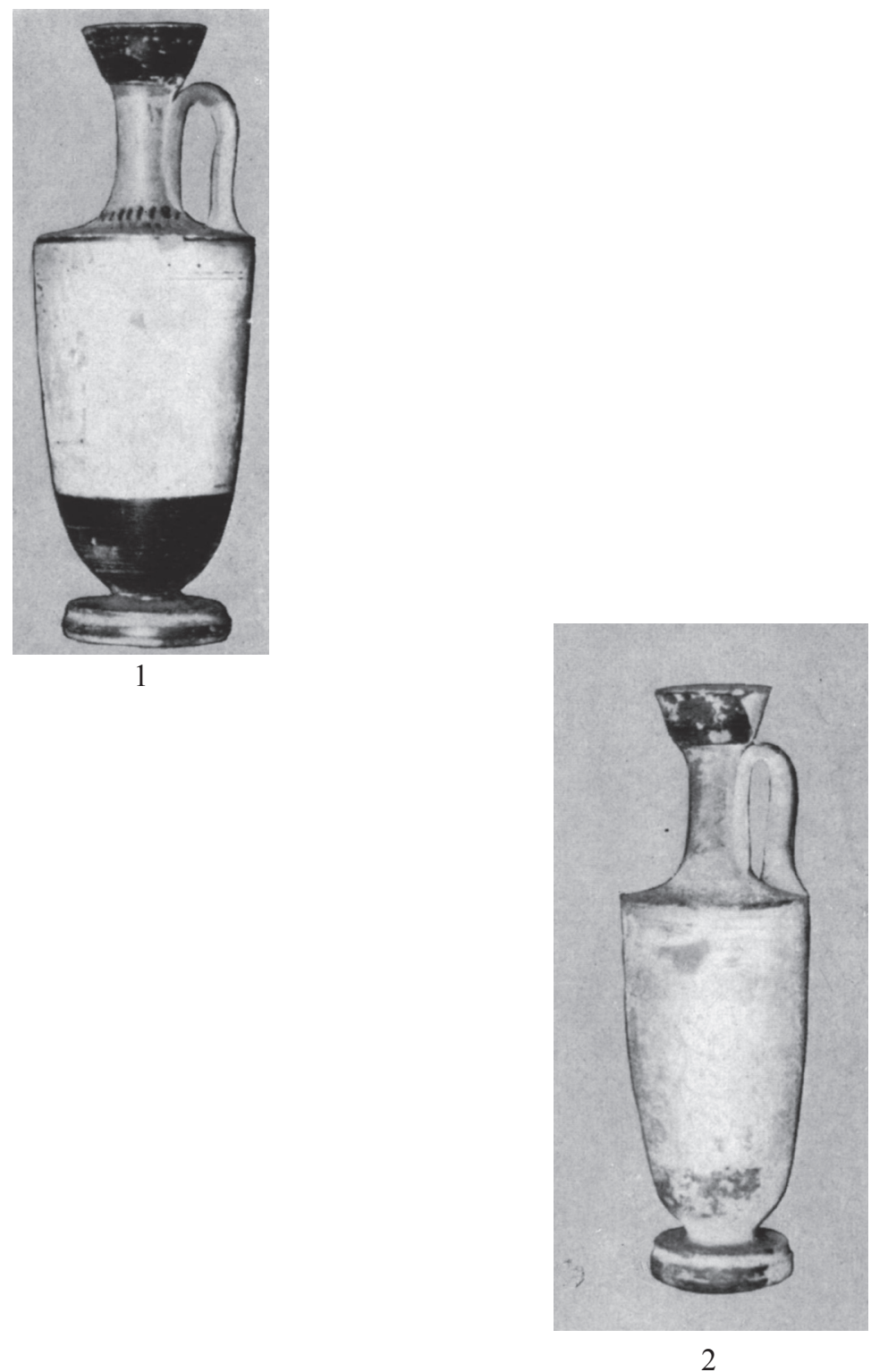


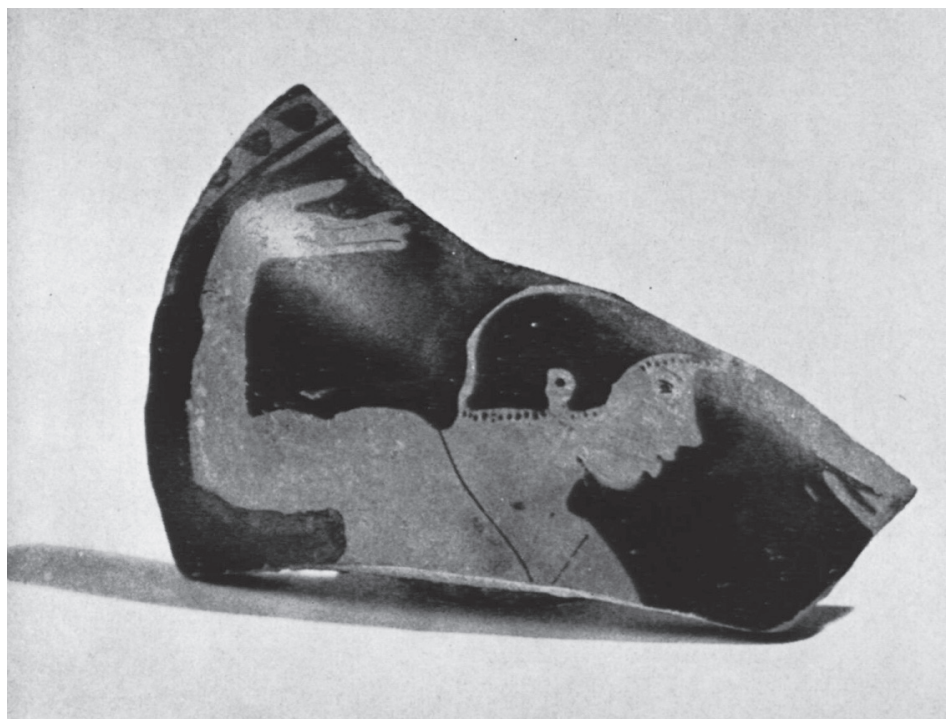


XXII

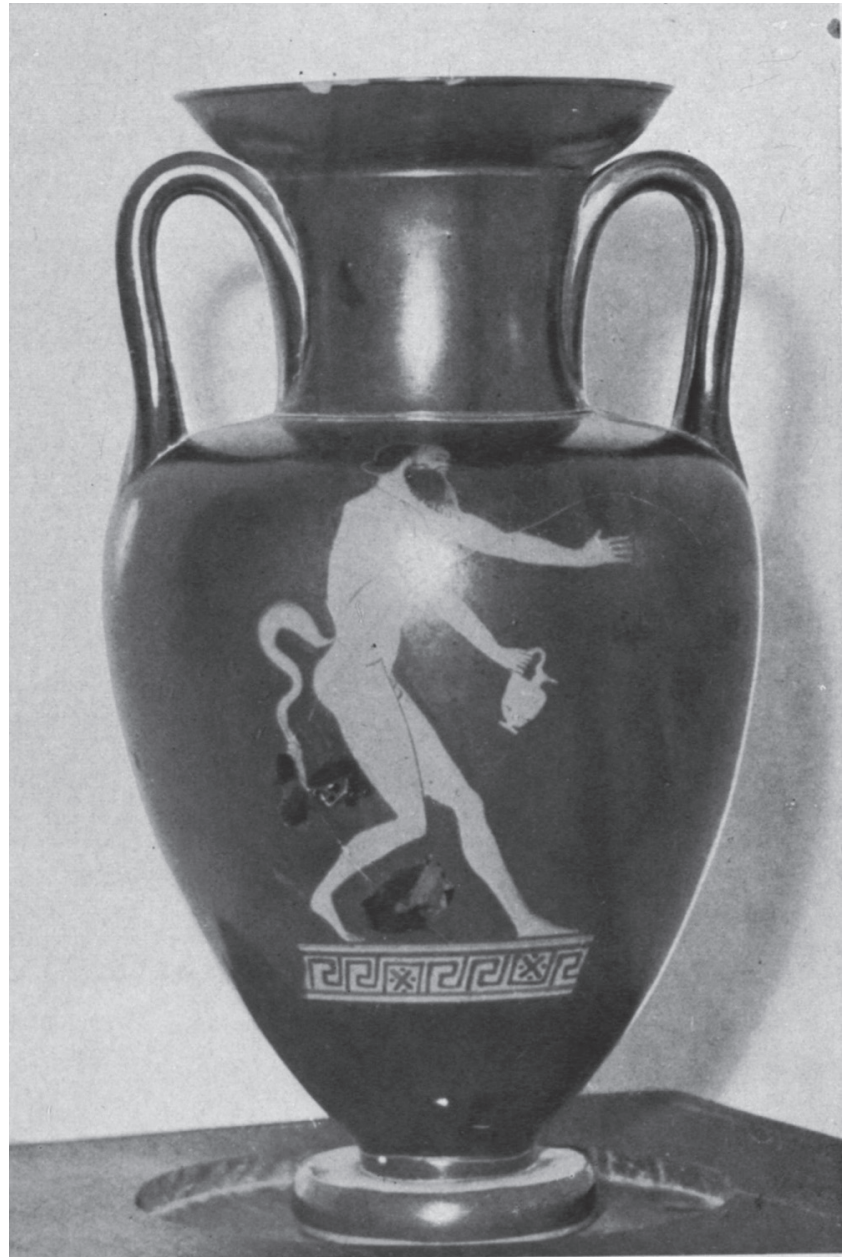




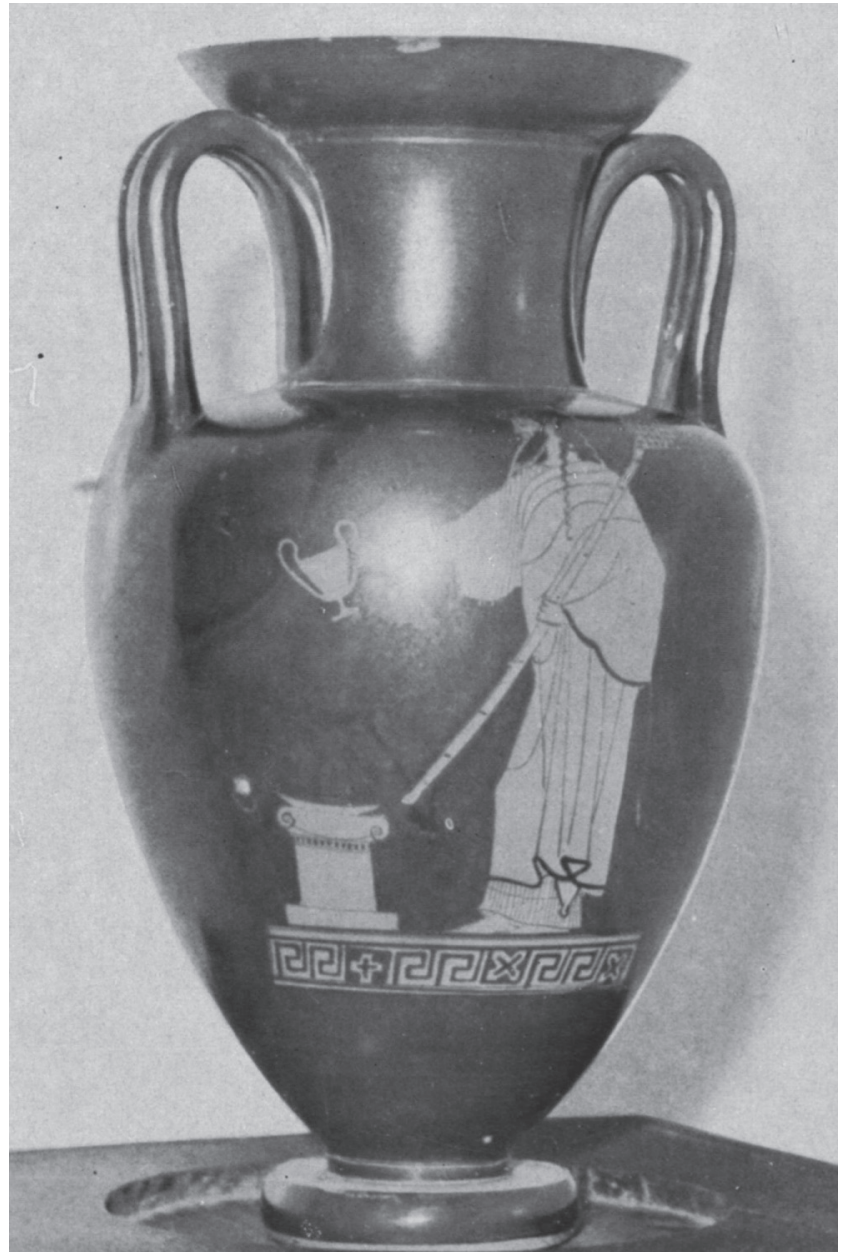


XXIV

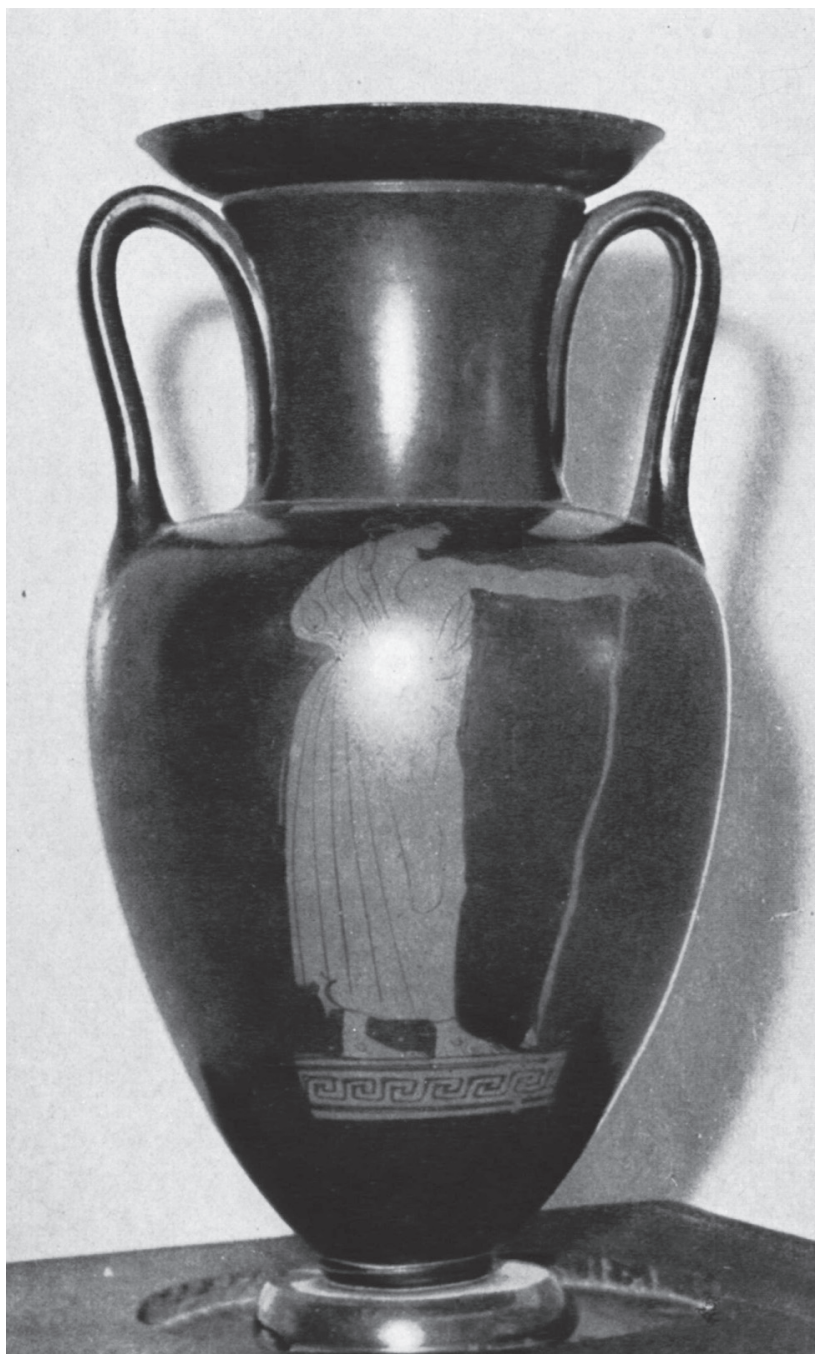




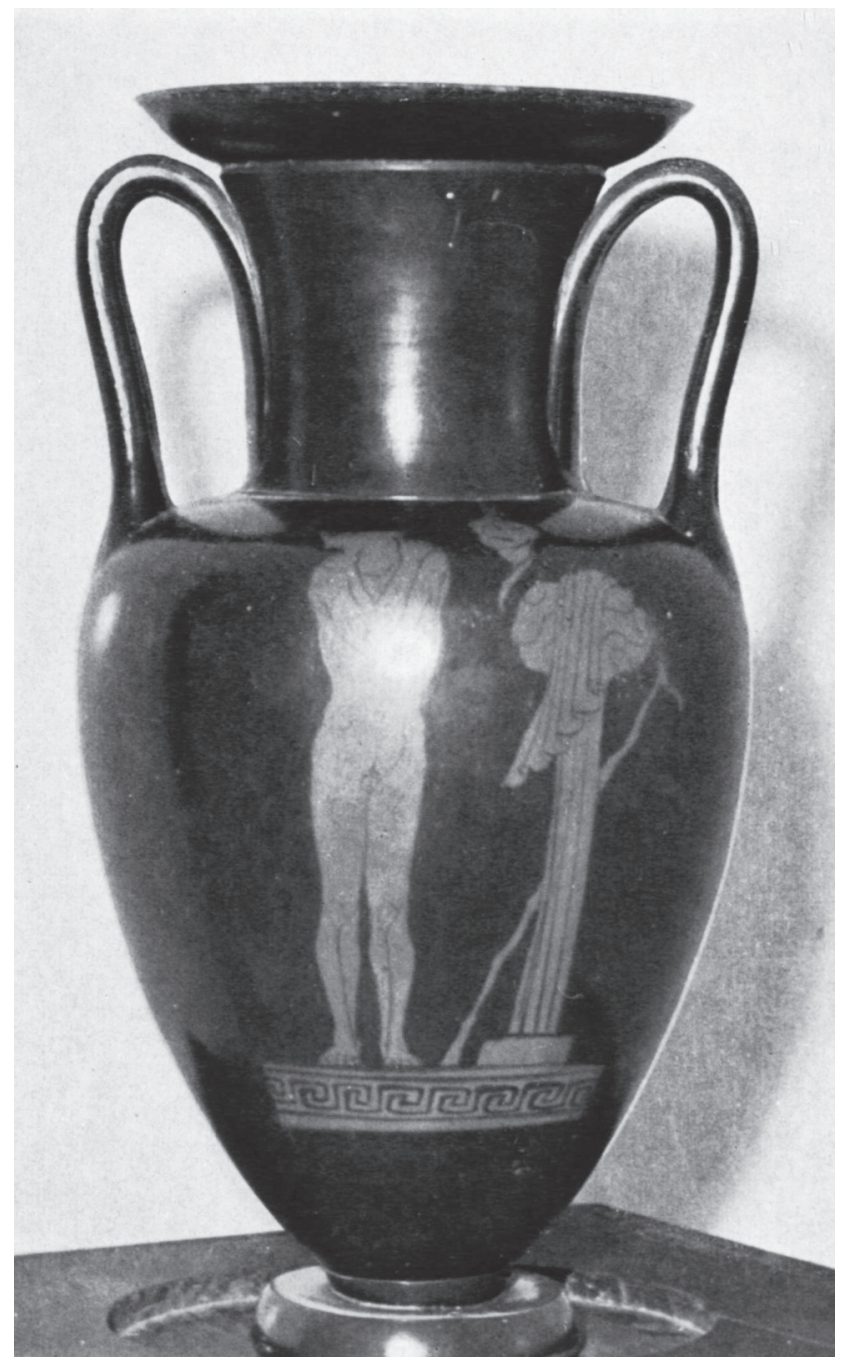




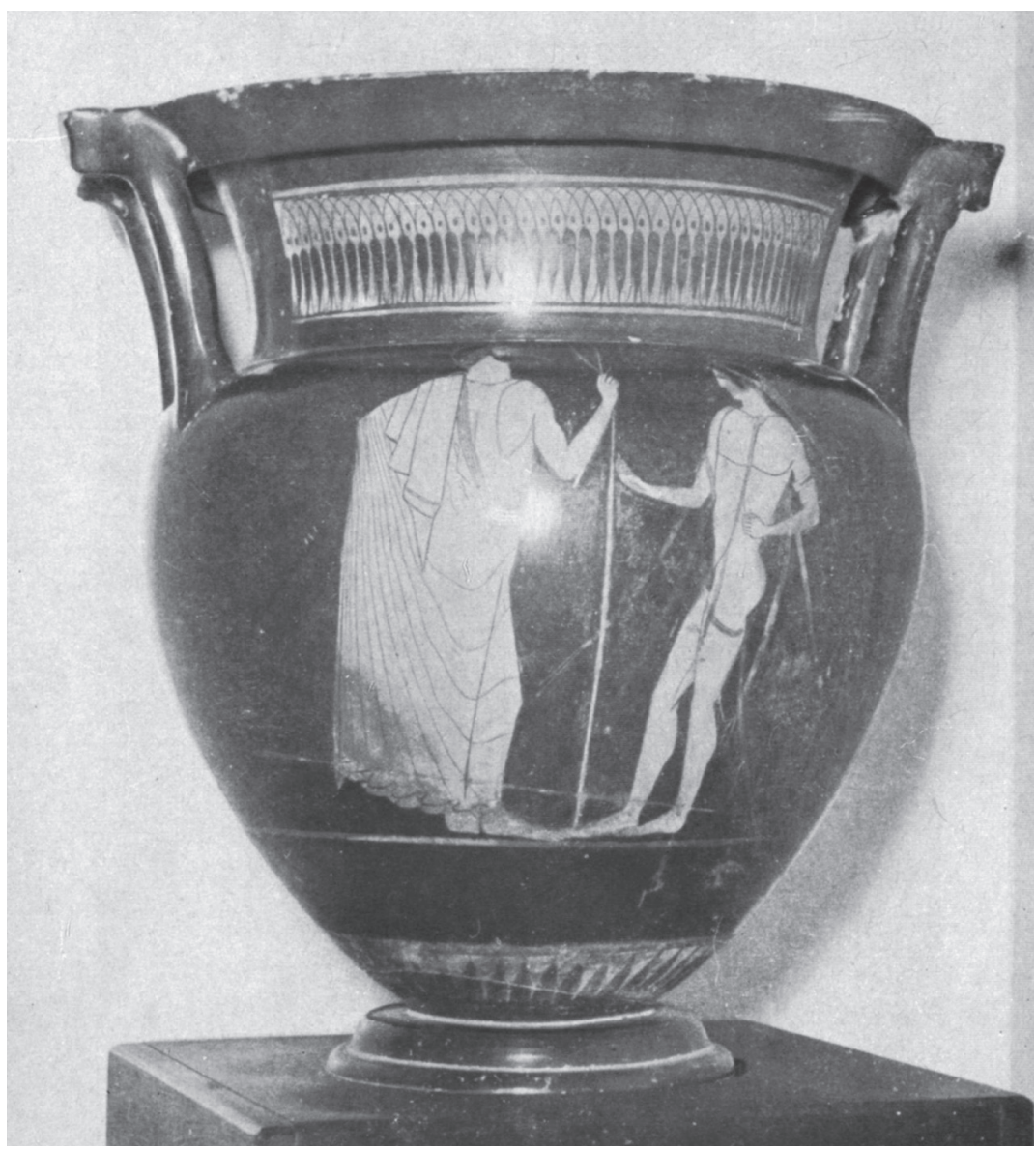




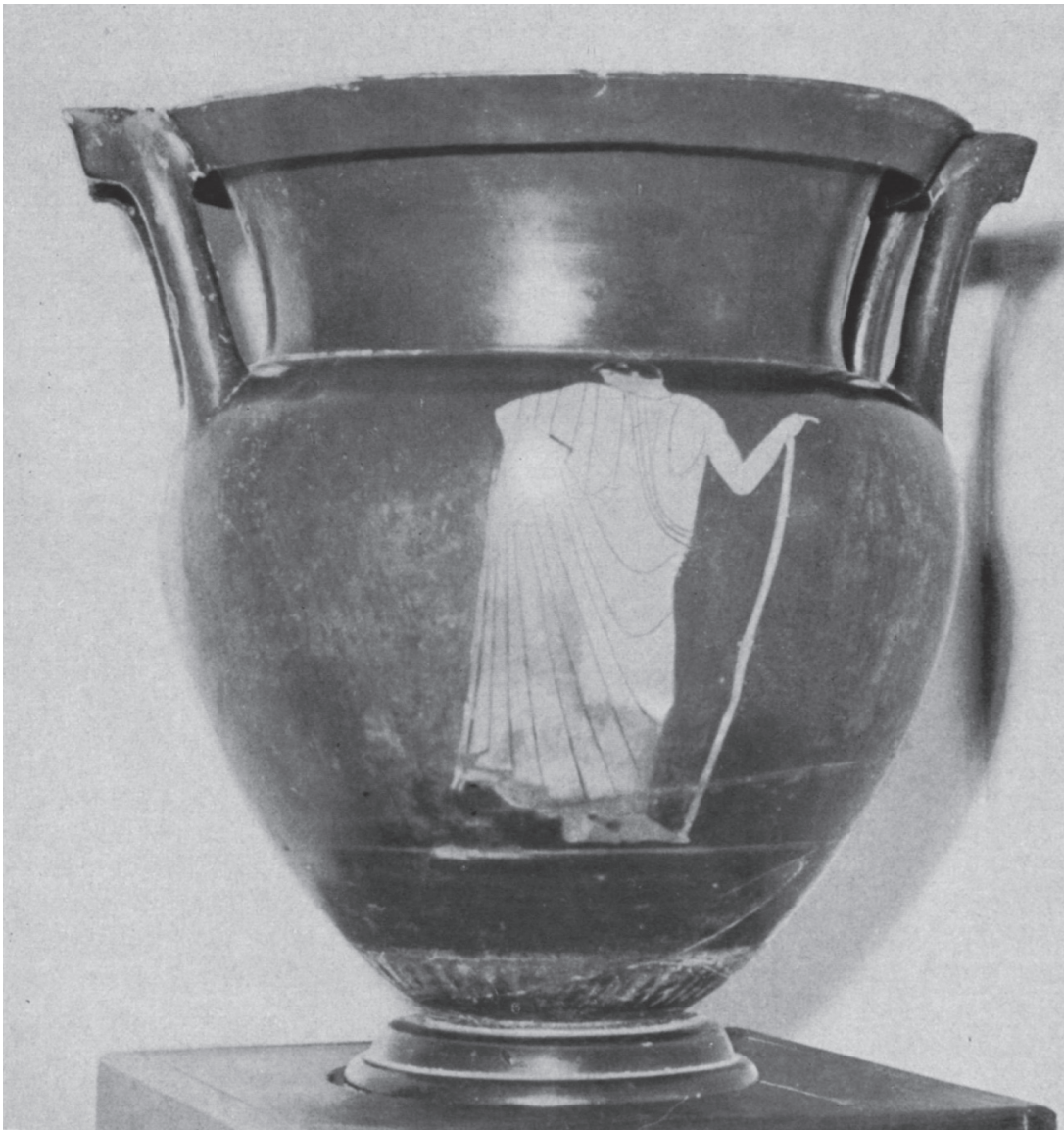




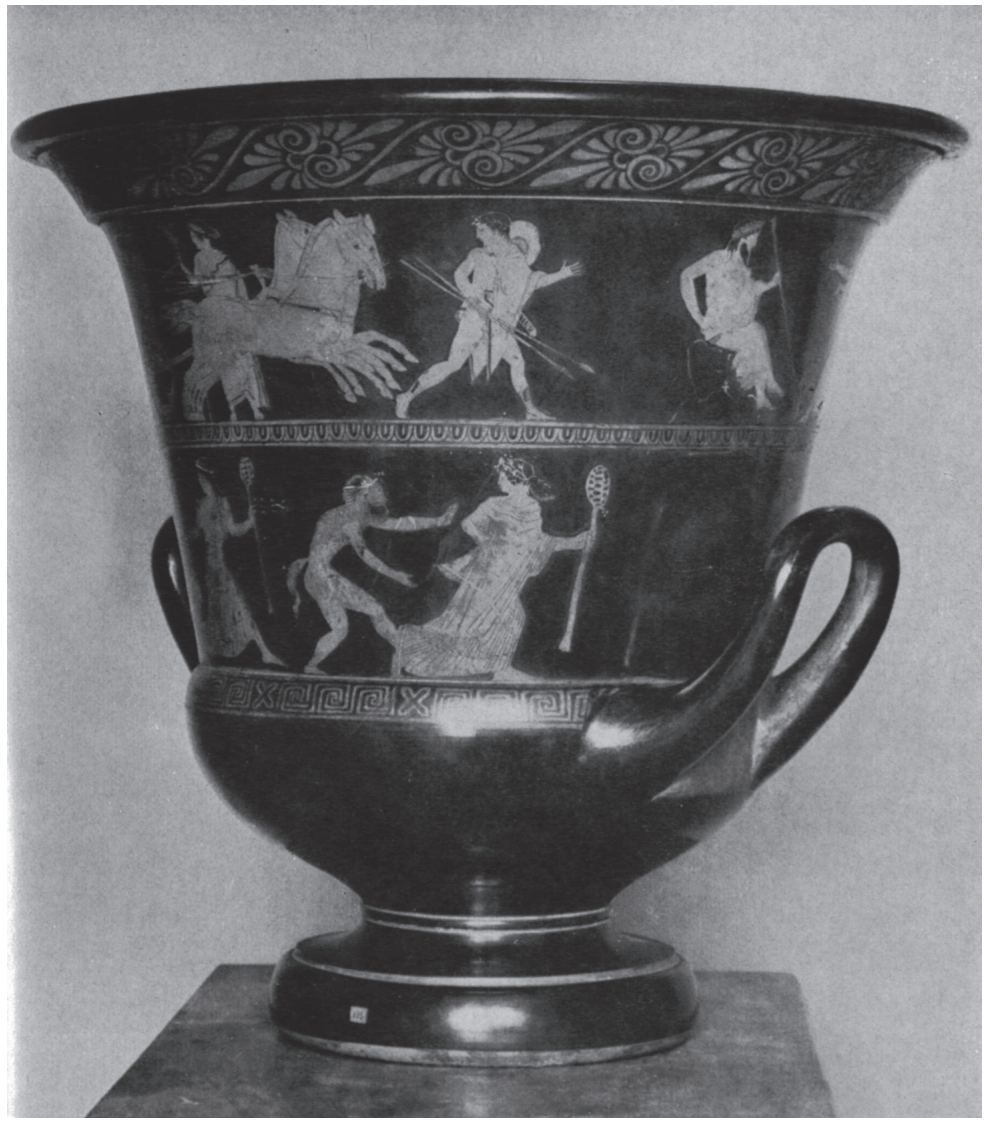




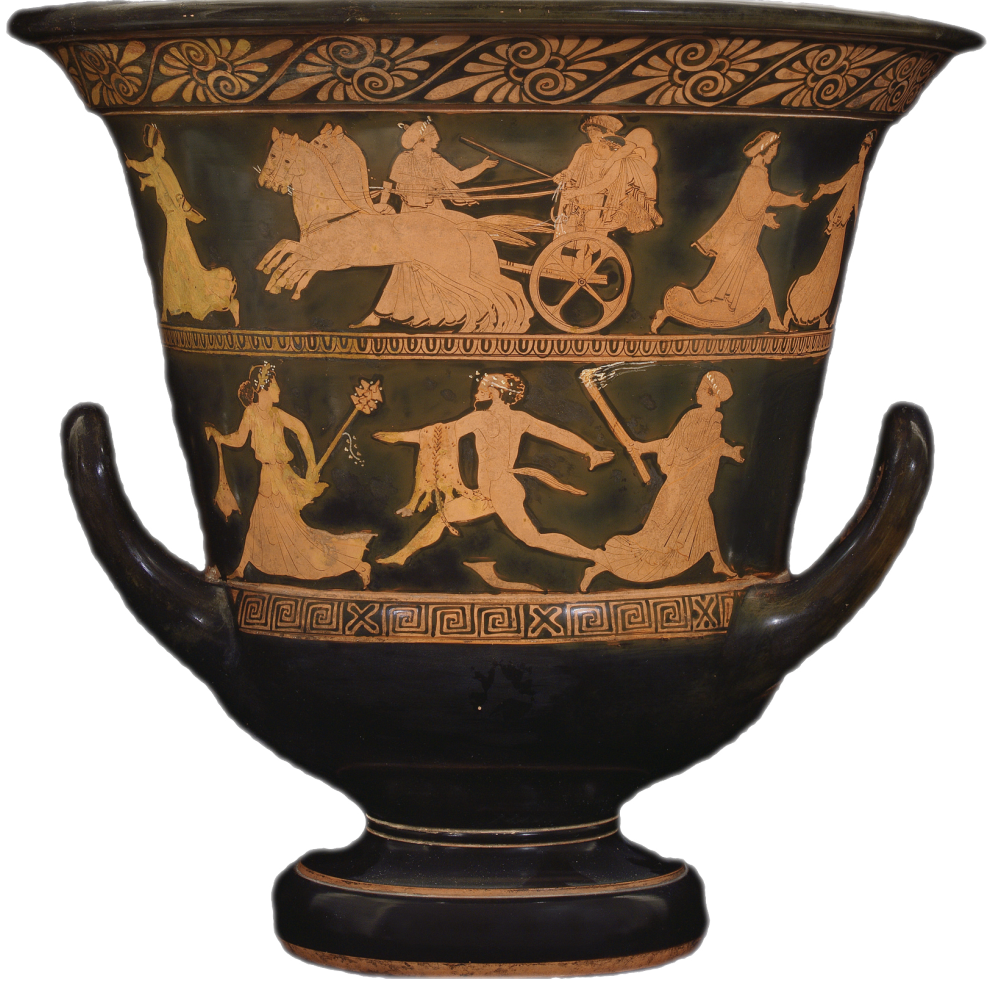




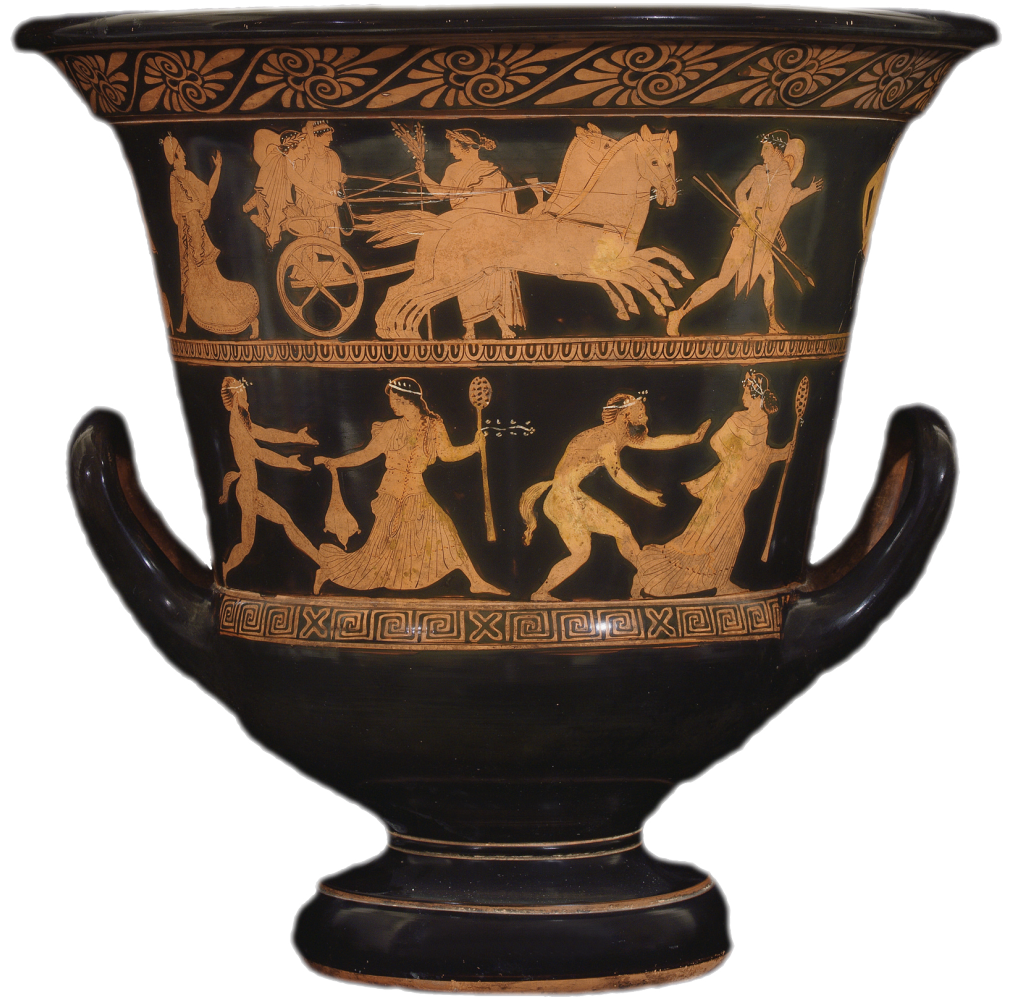




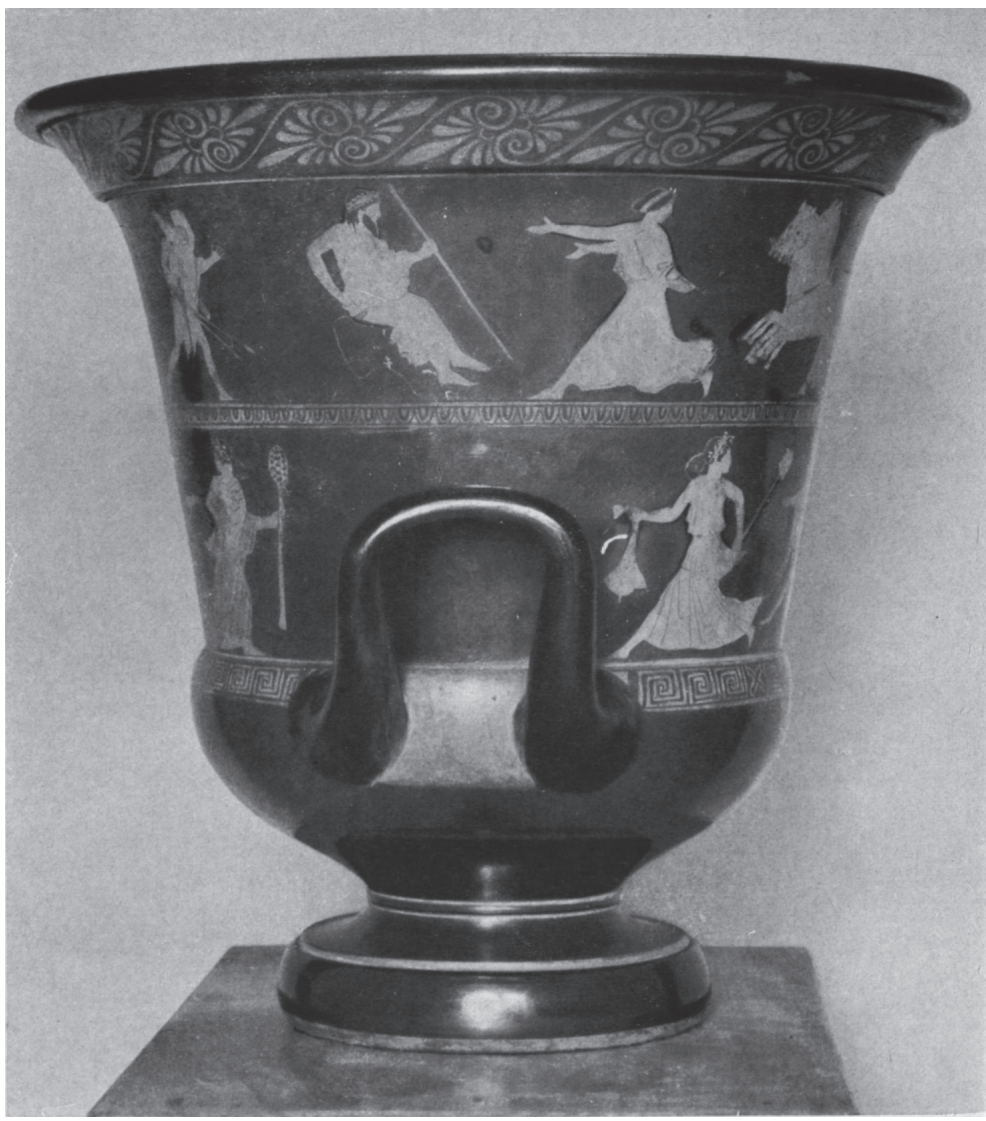




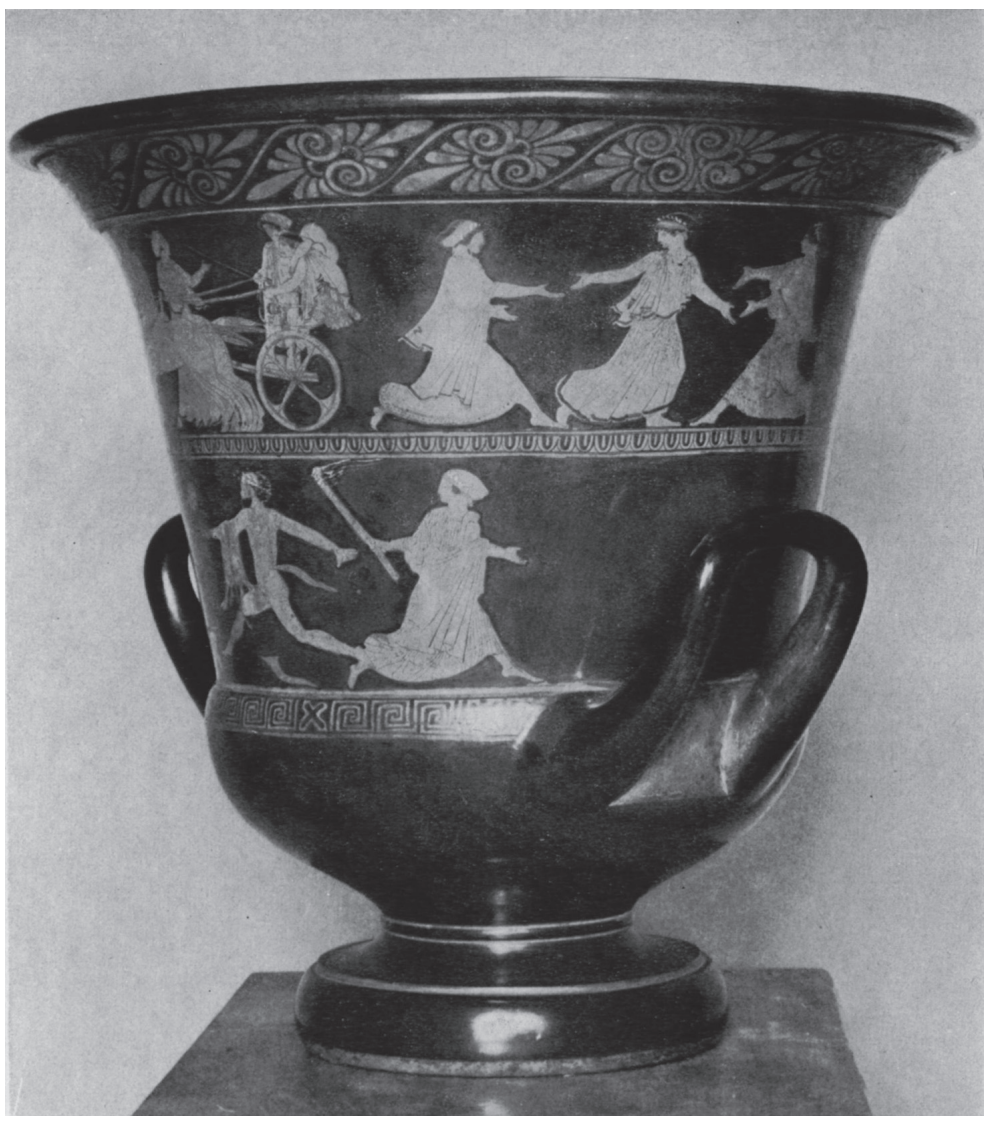




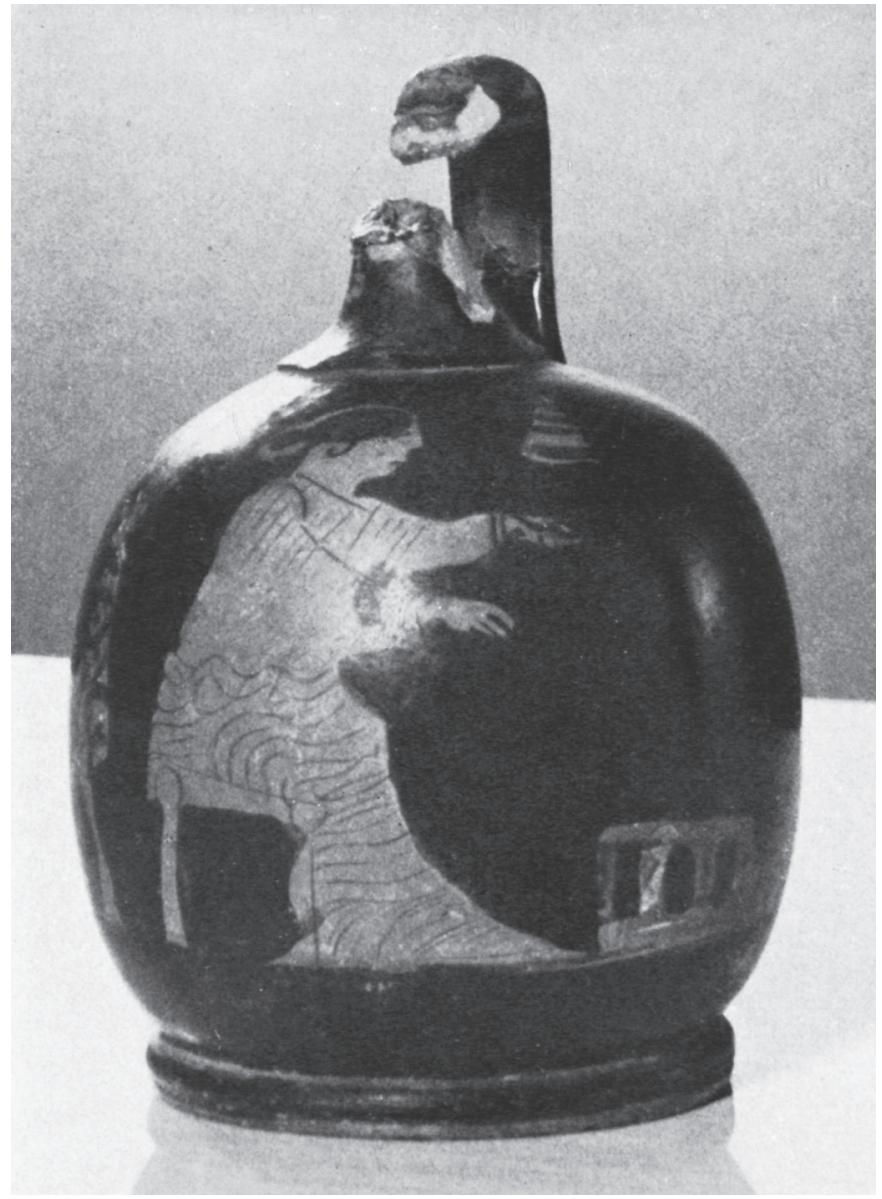


XXXIV

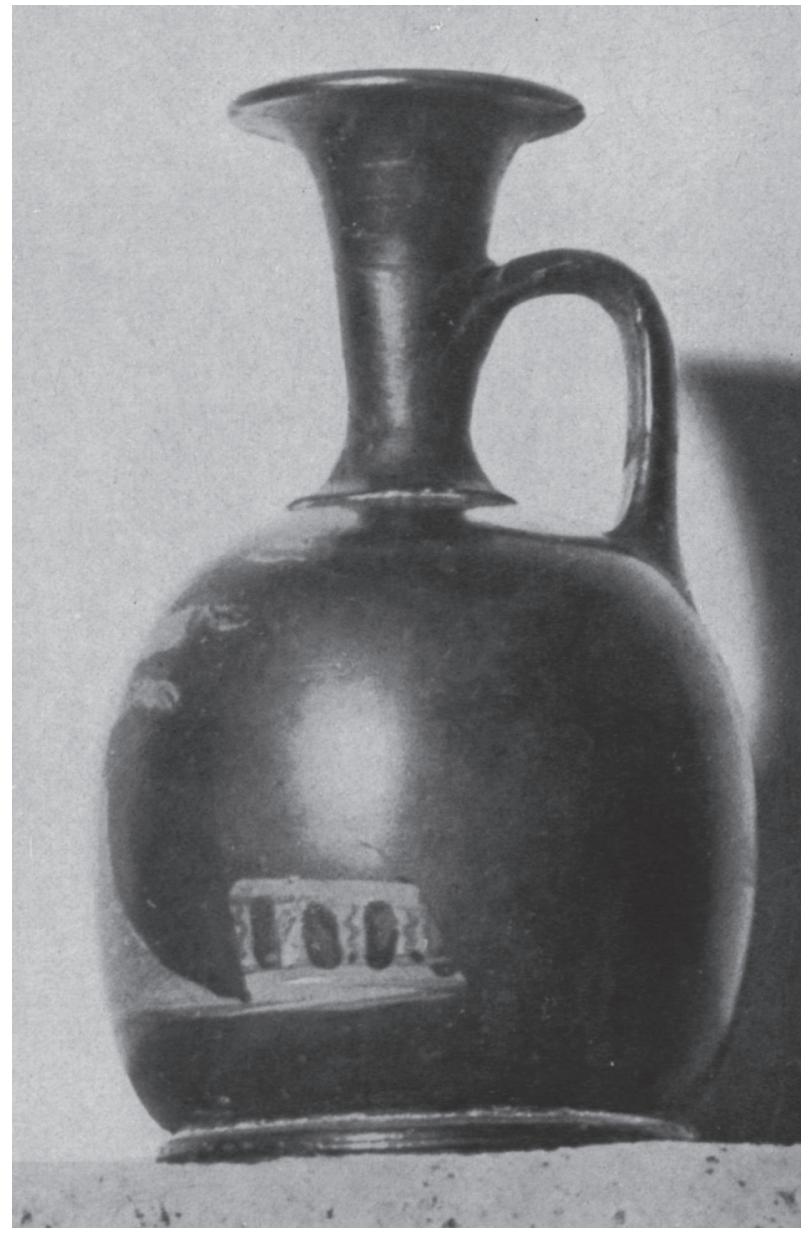




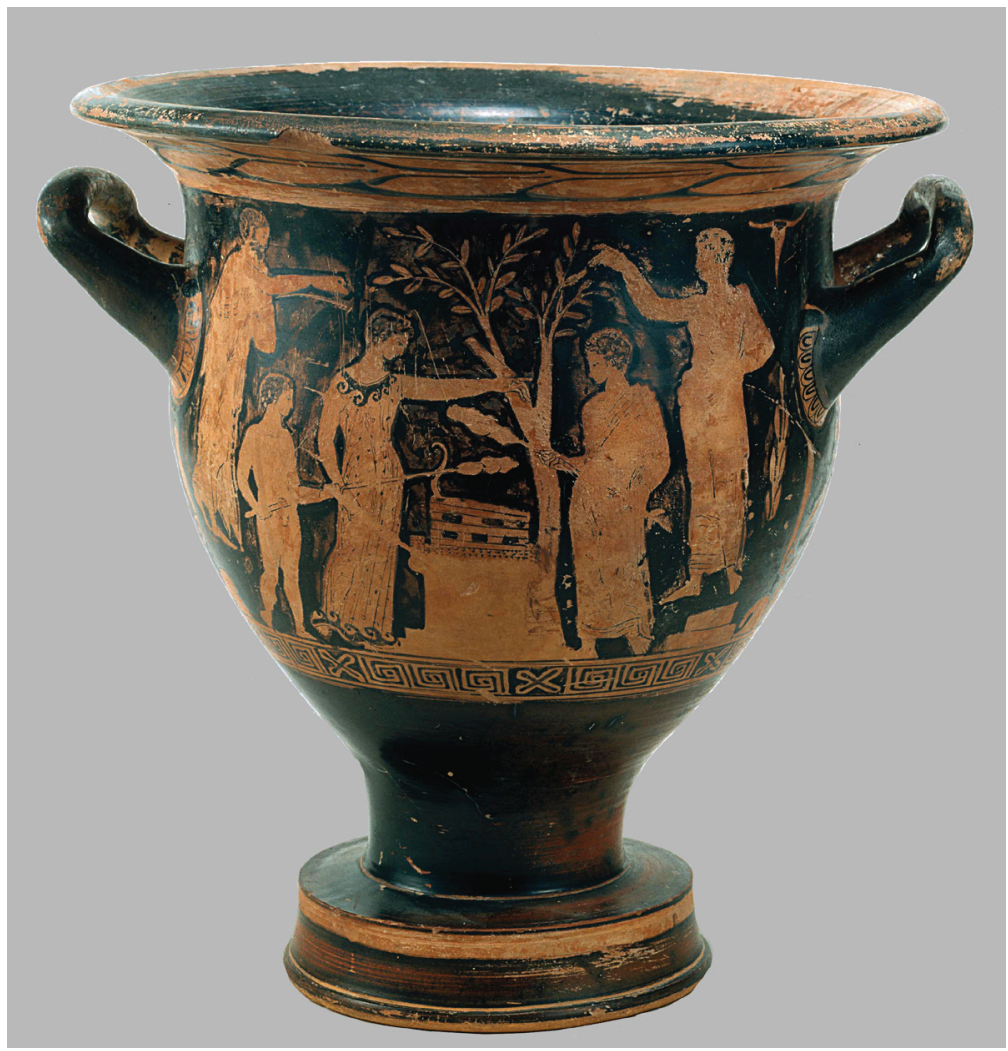




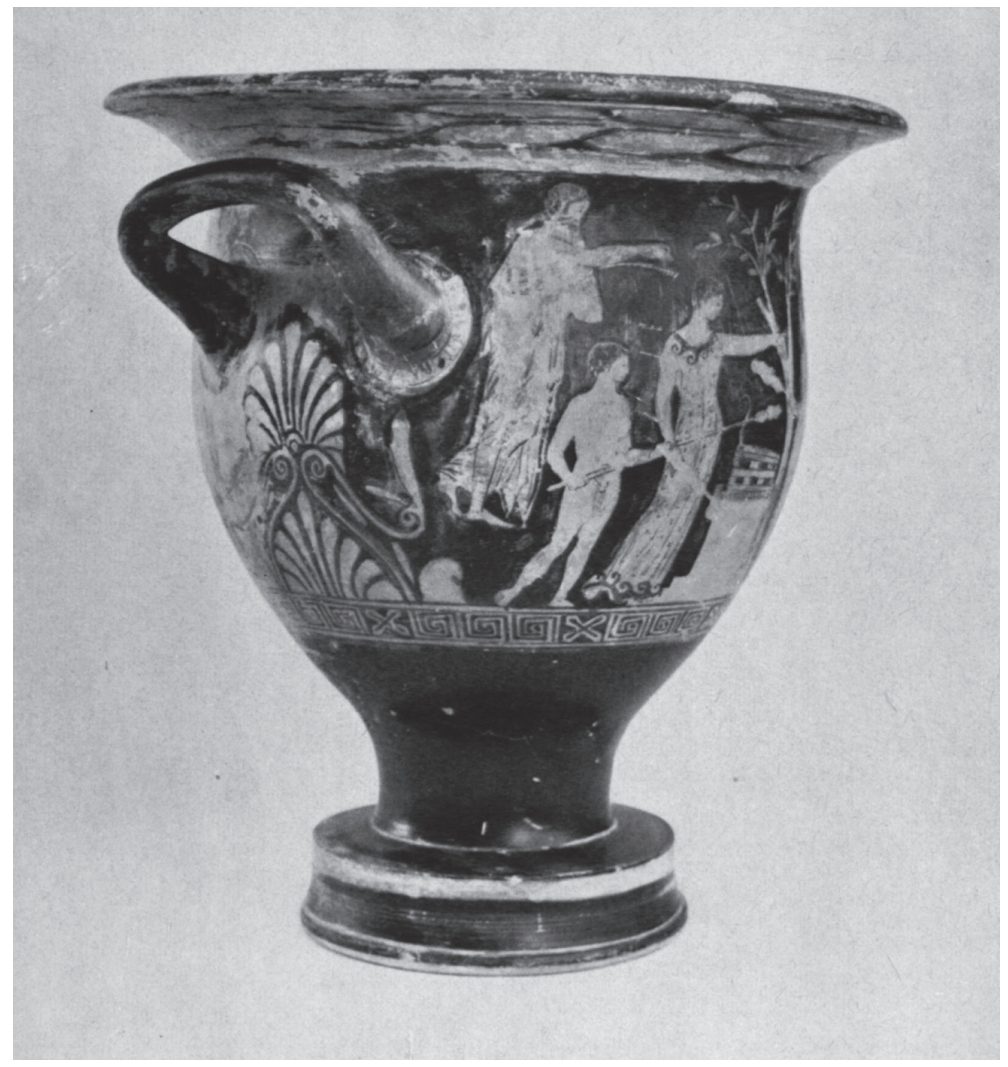




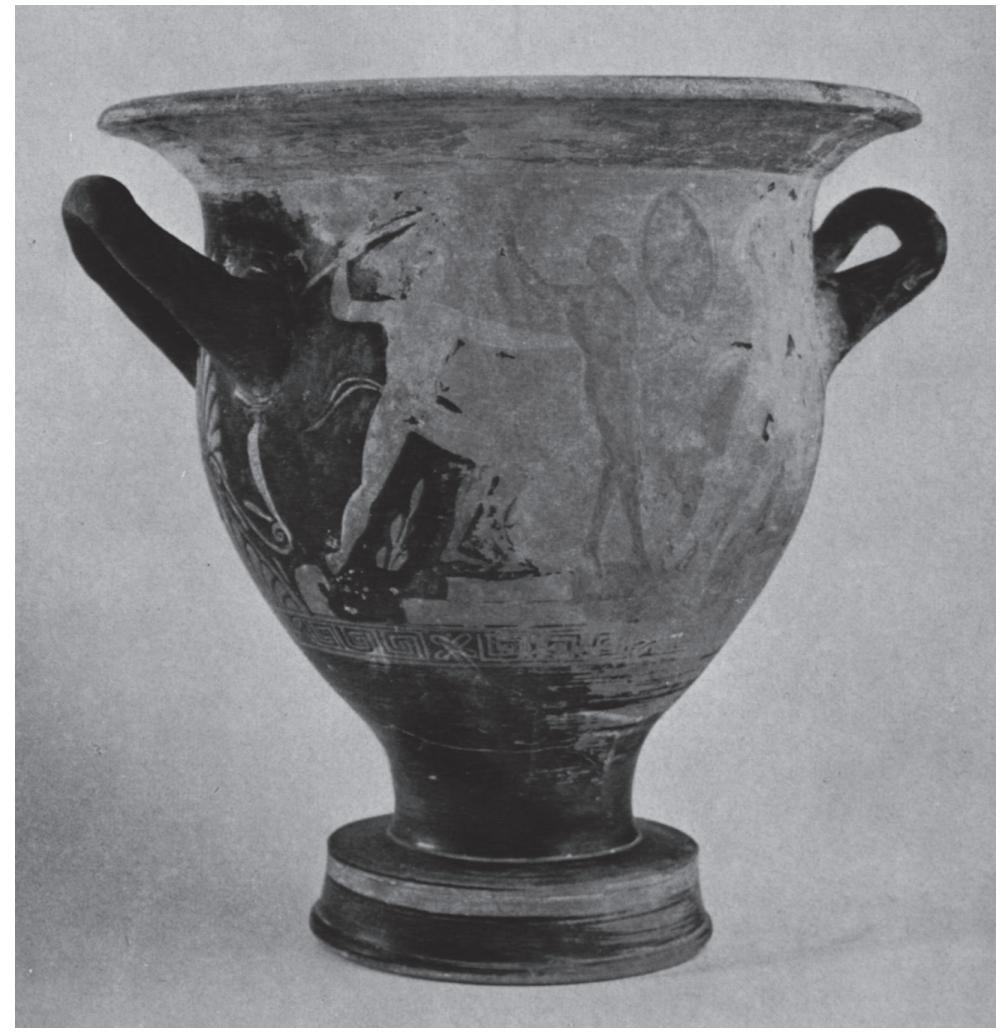


XXXVIII

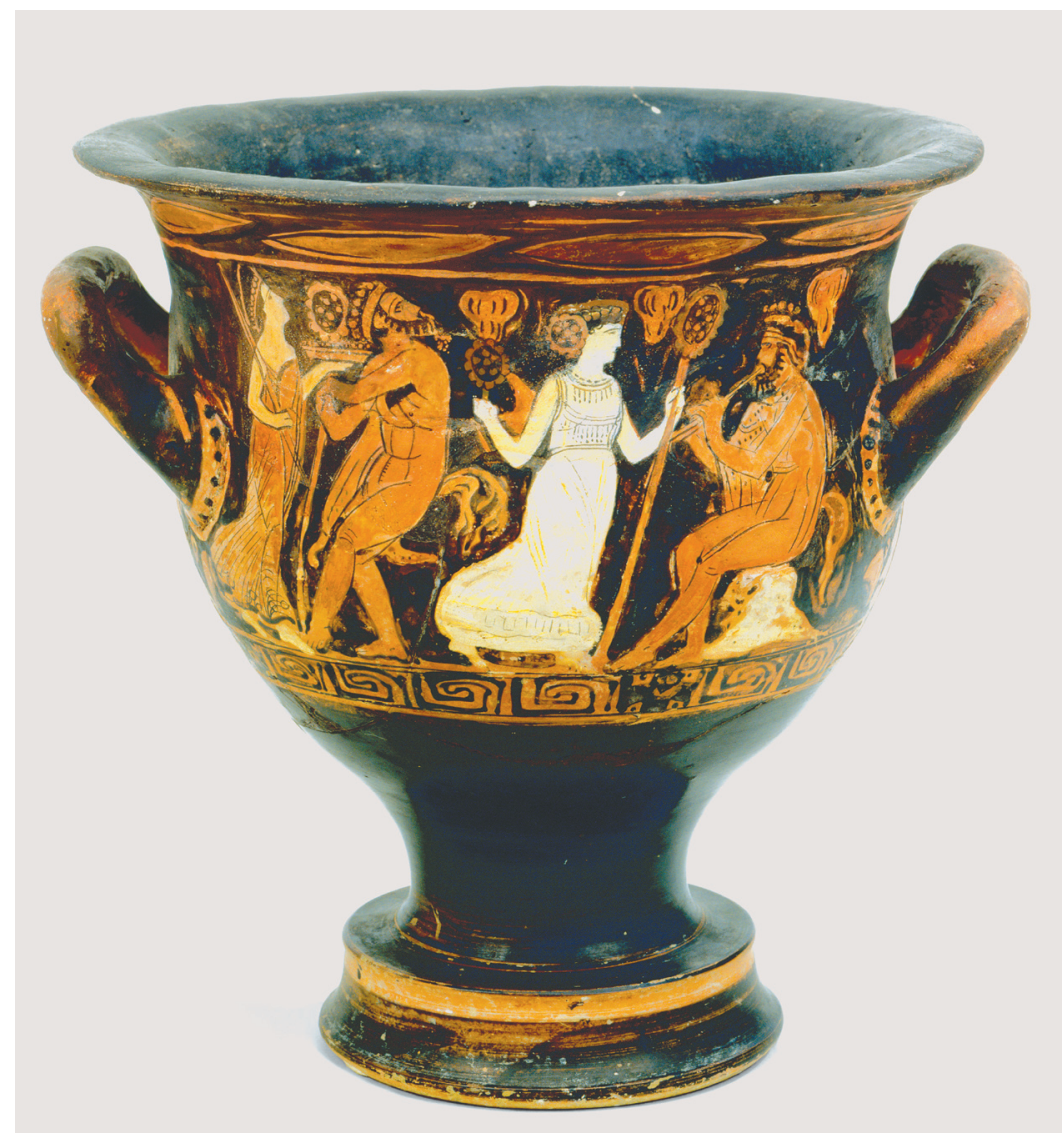




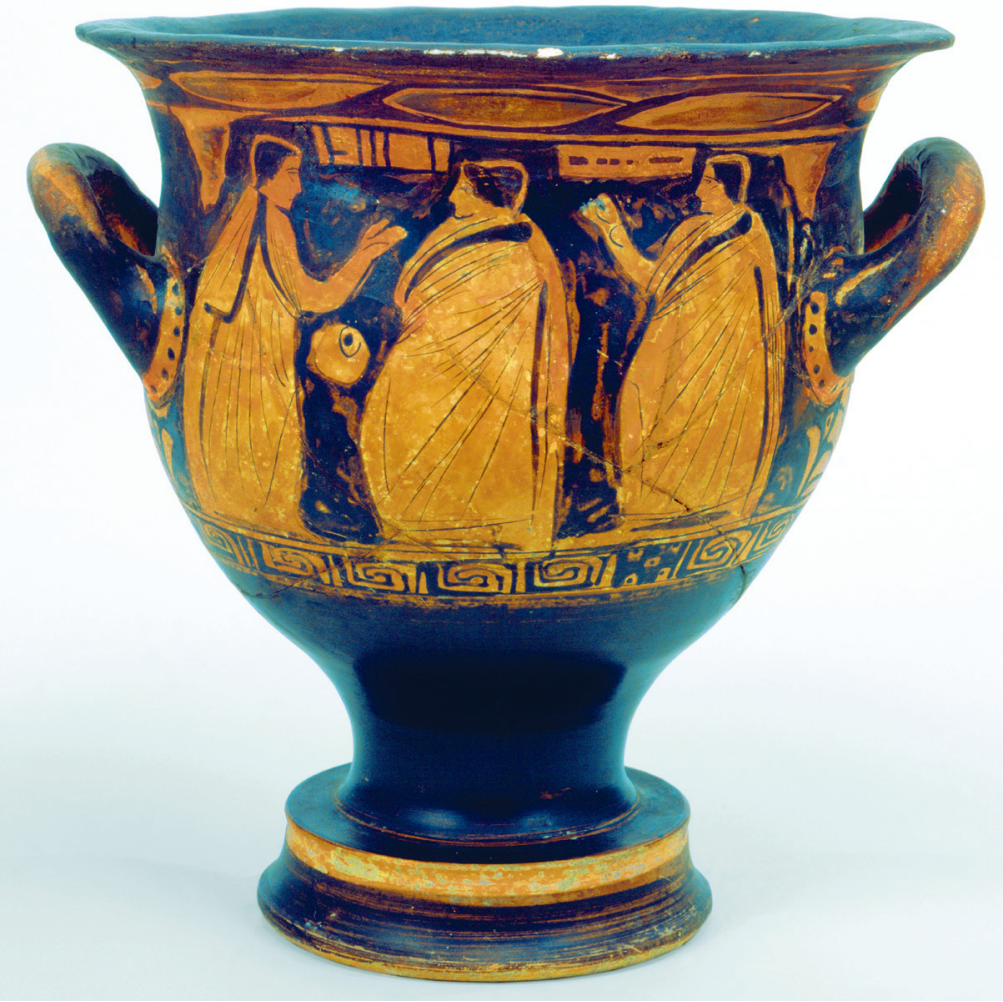




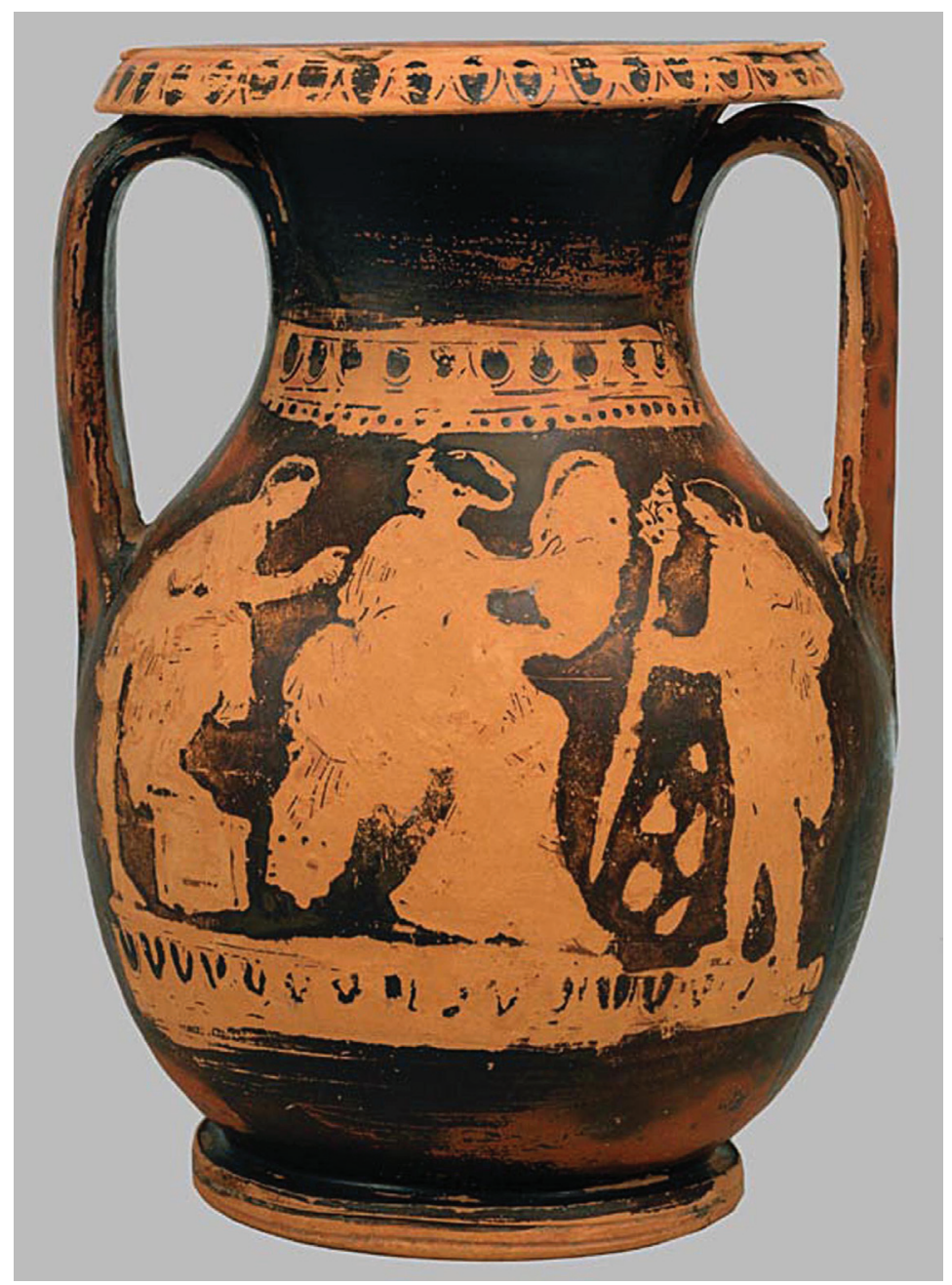




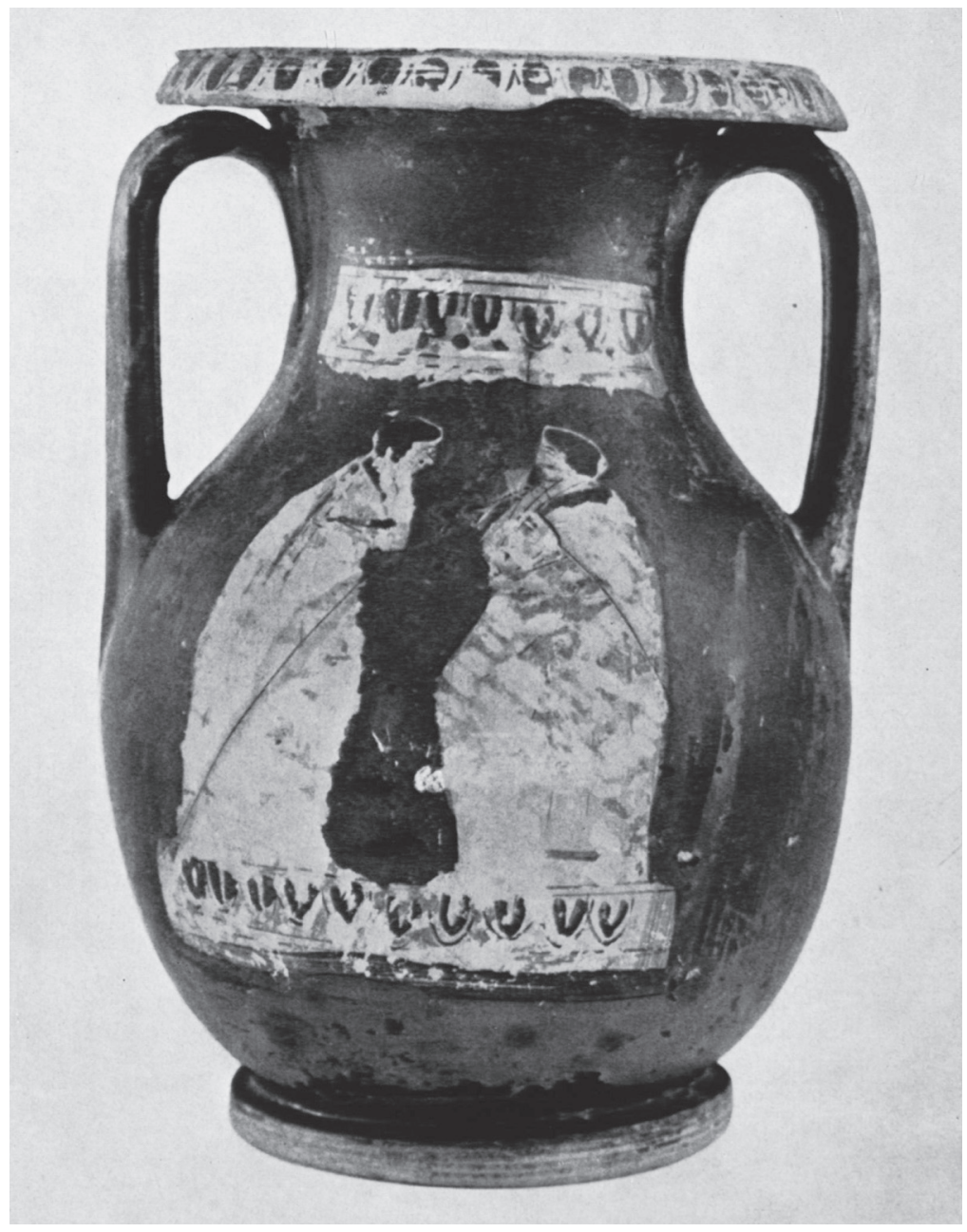


XLII
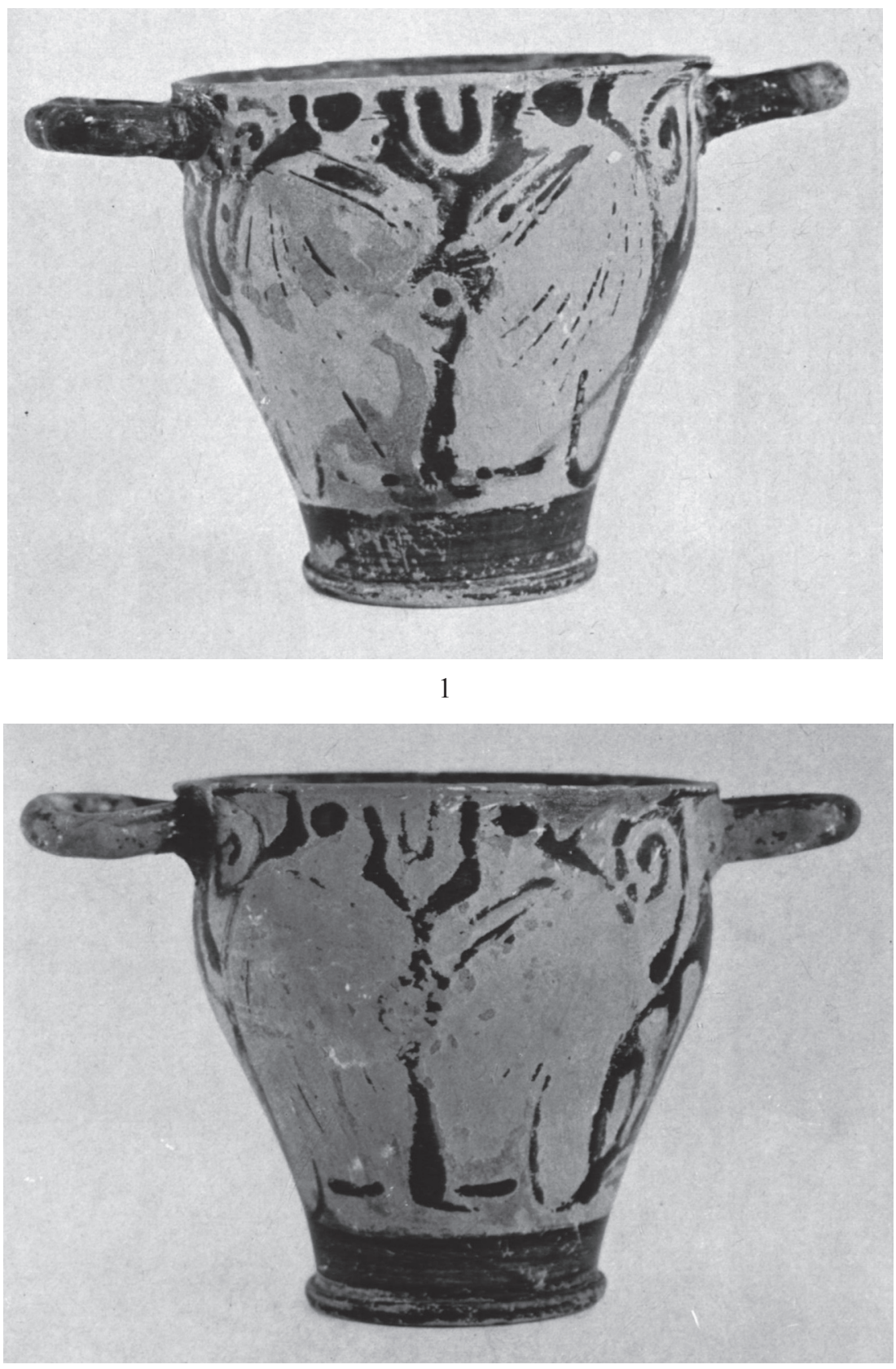

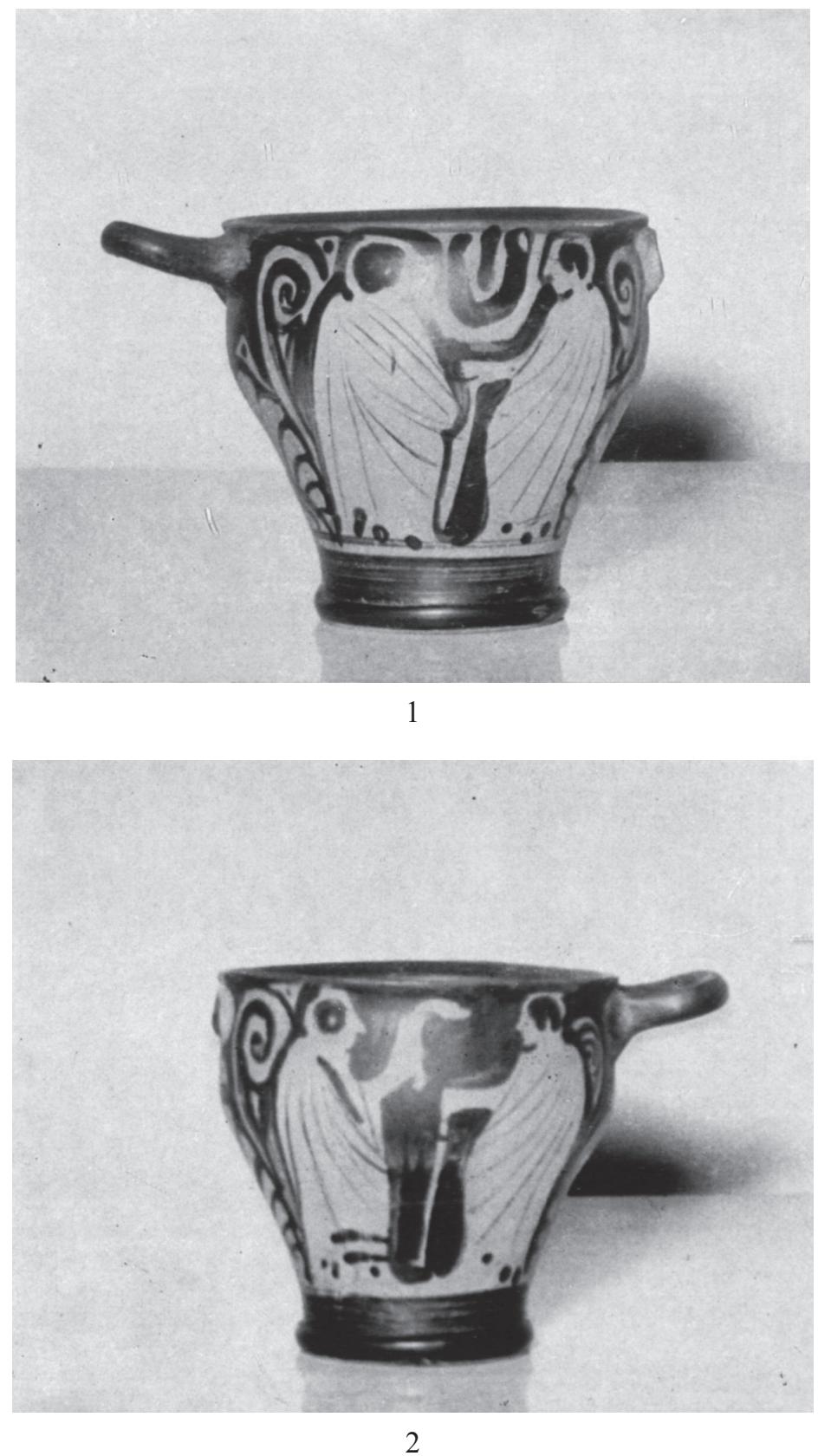
XLIV

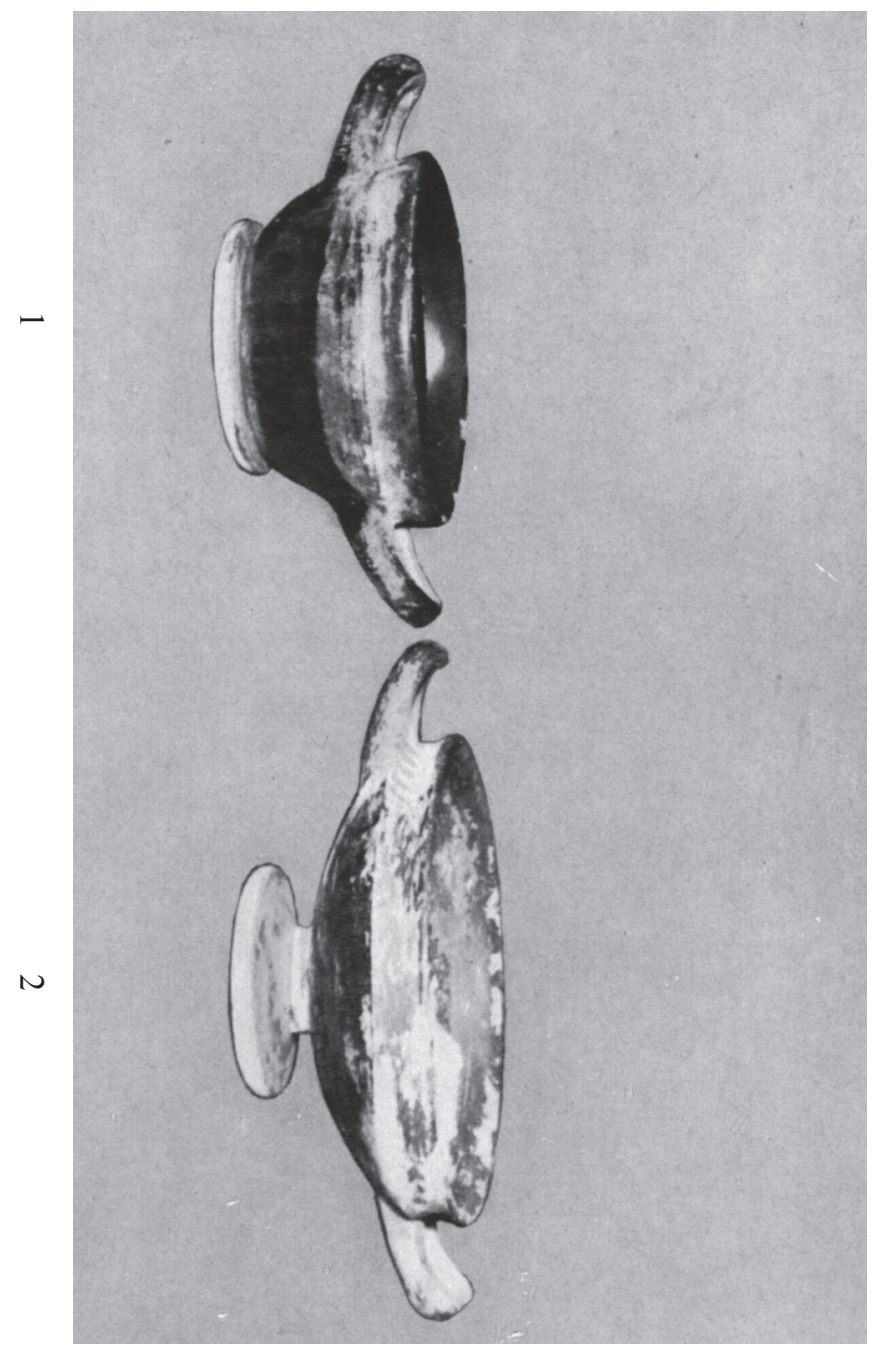



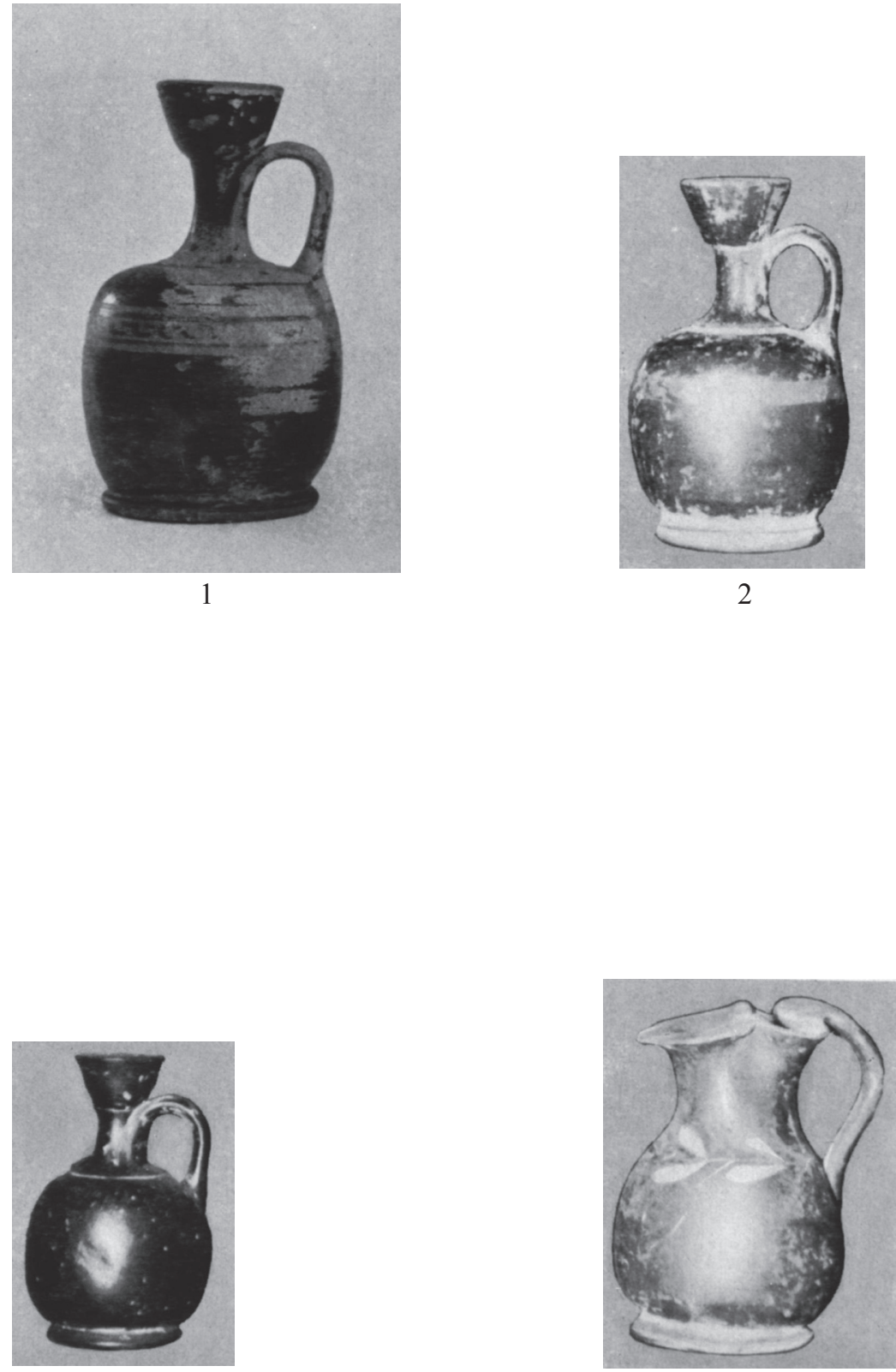
XLVI

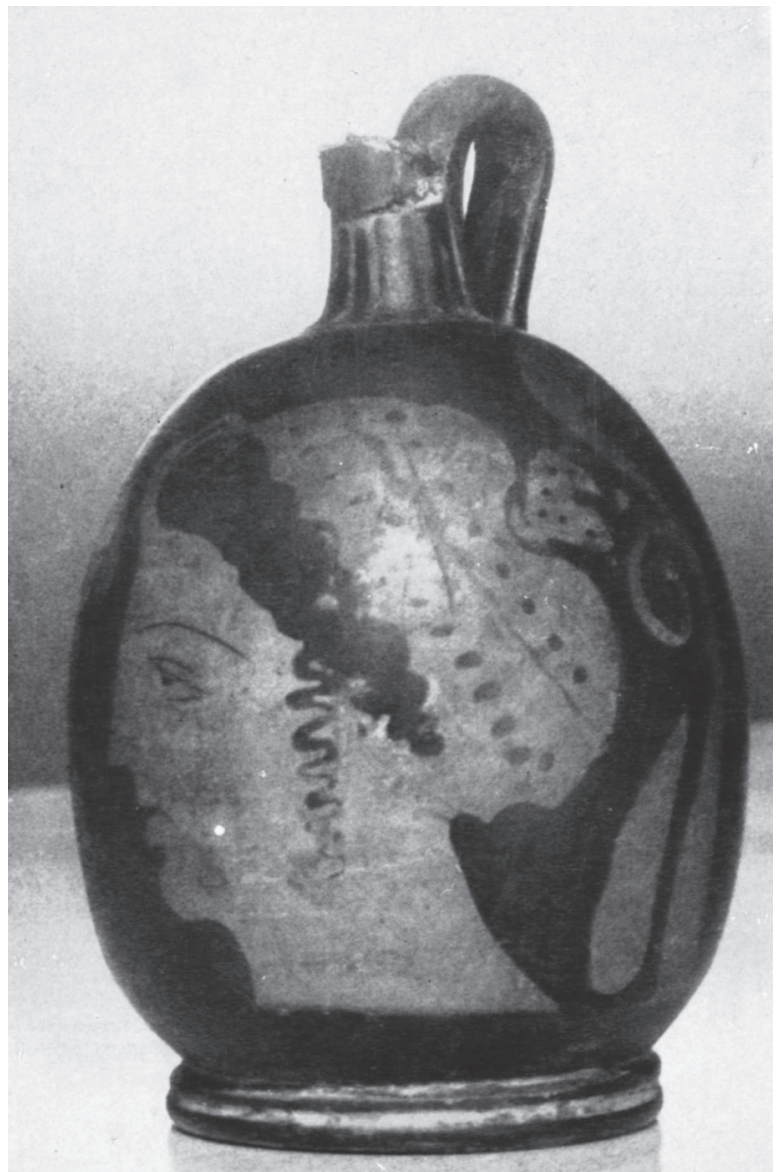




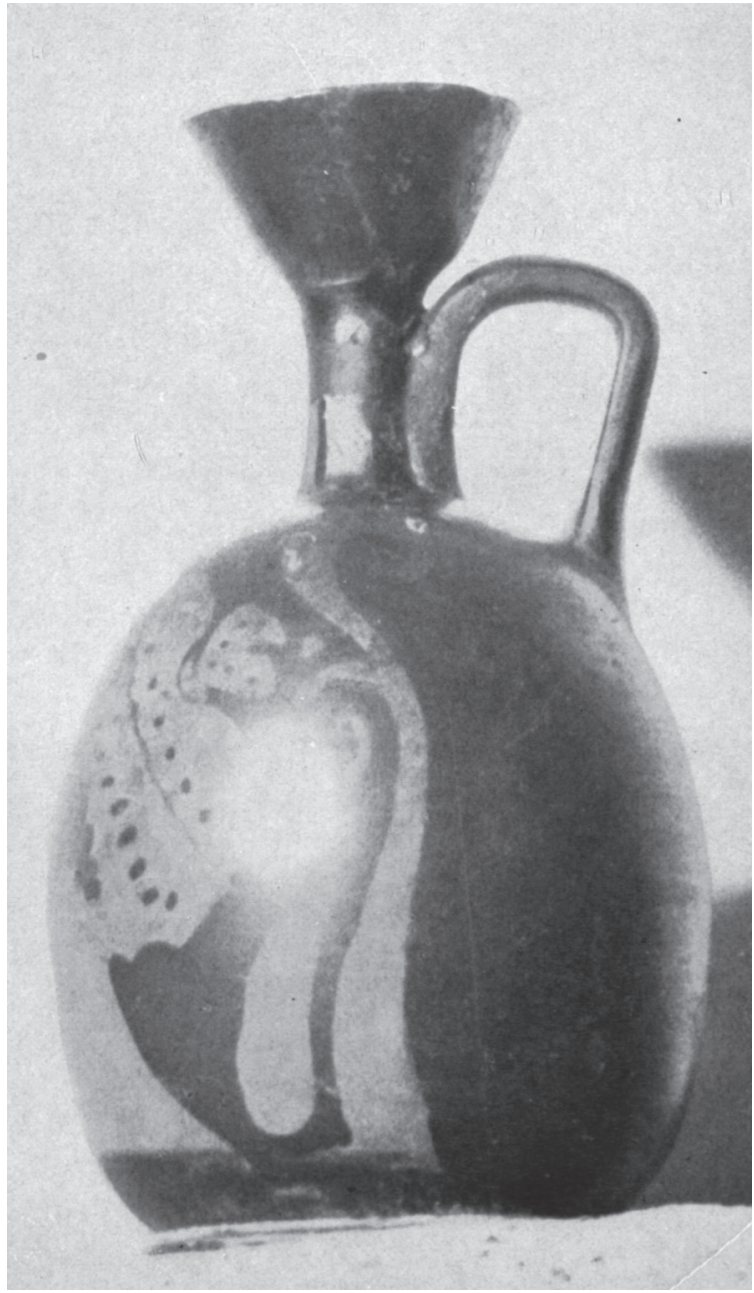


XLVIII
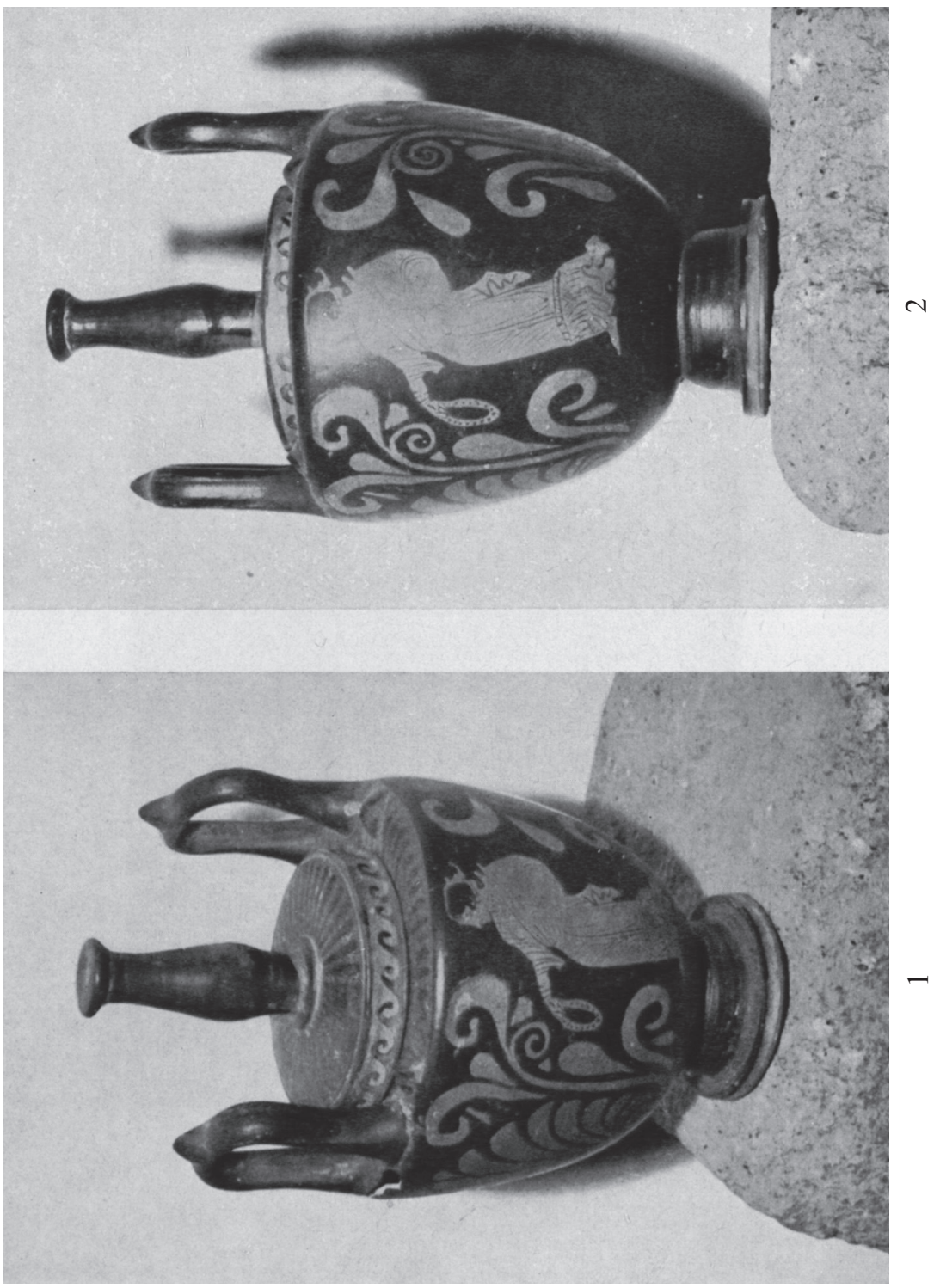

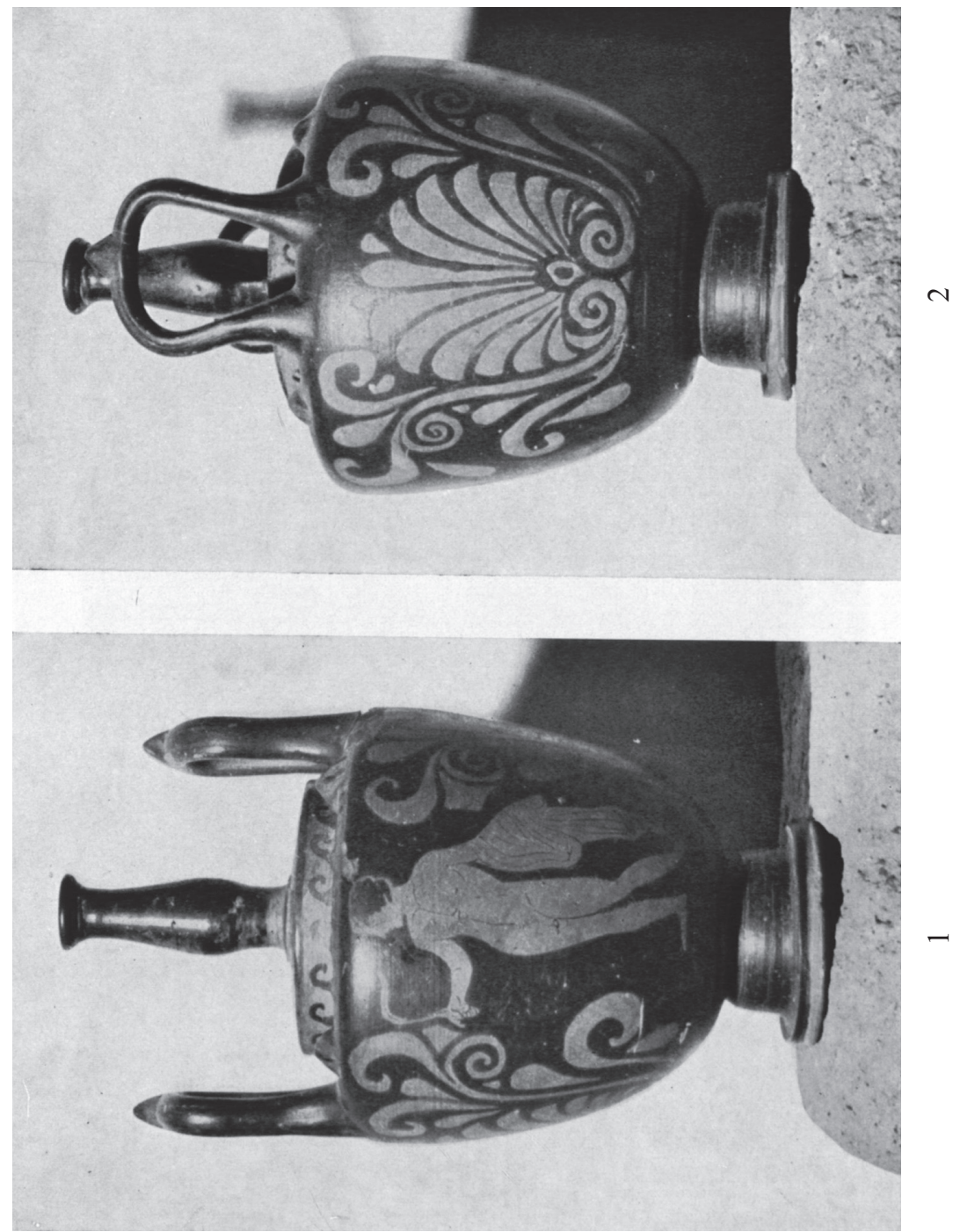


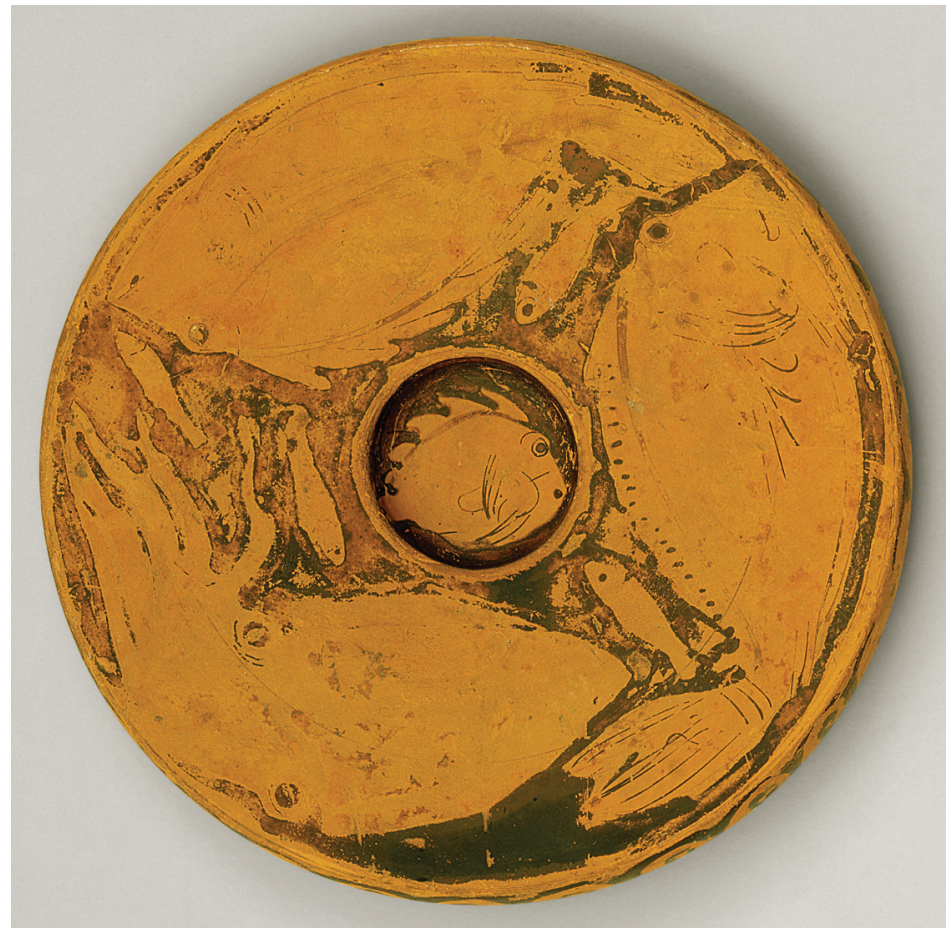




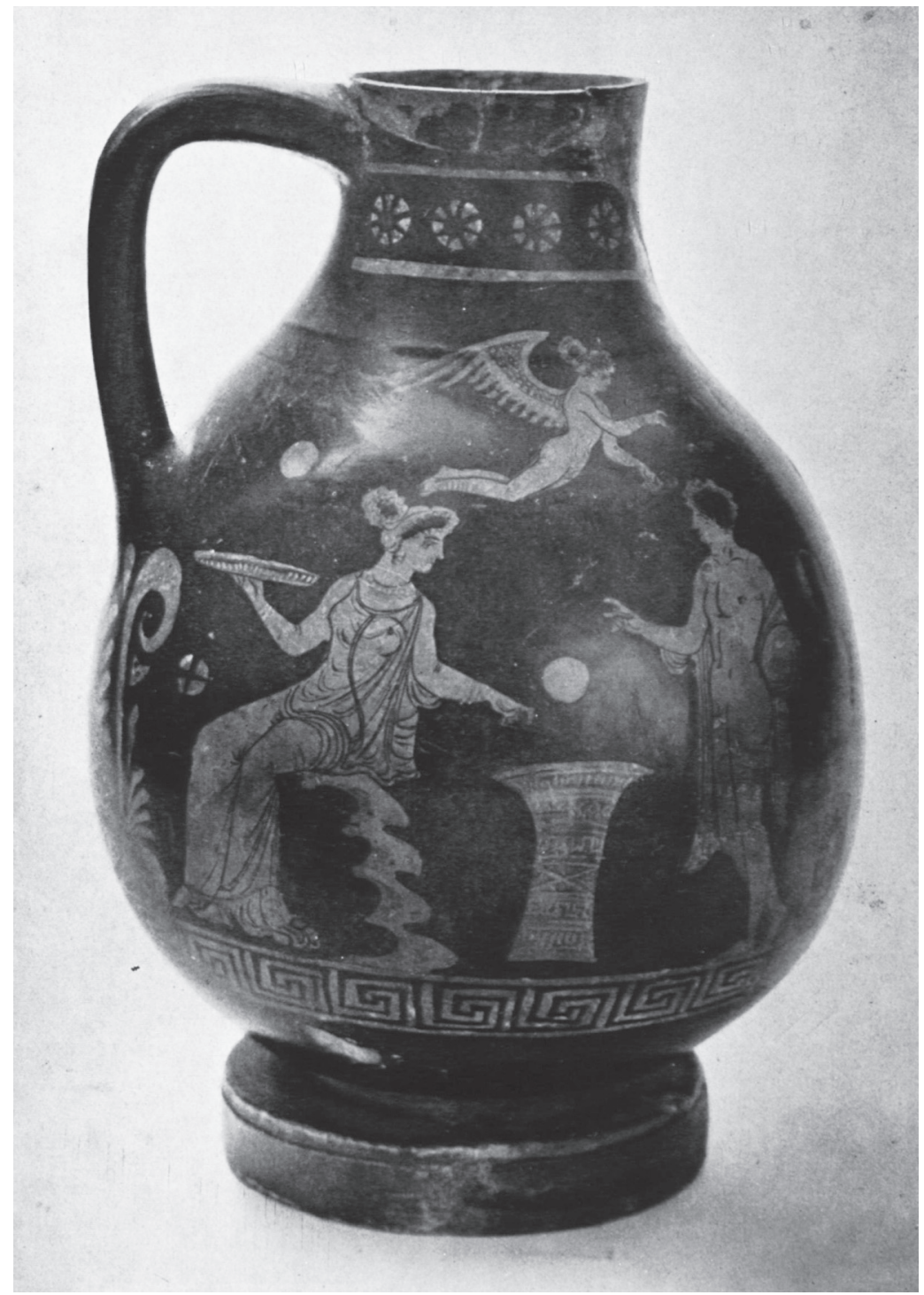


LII

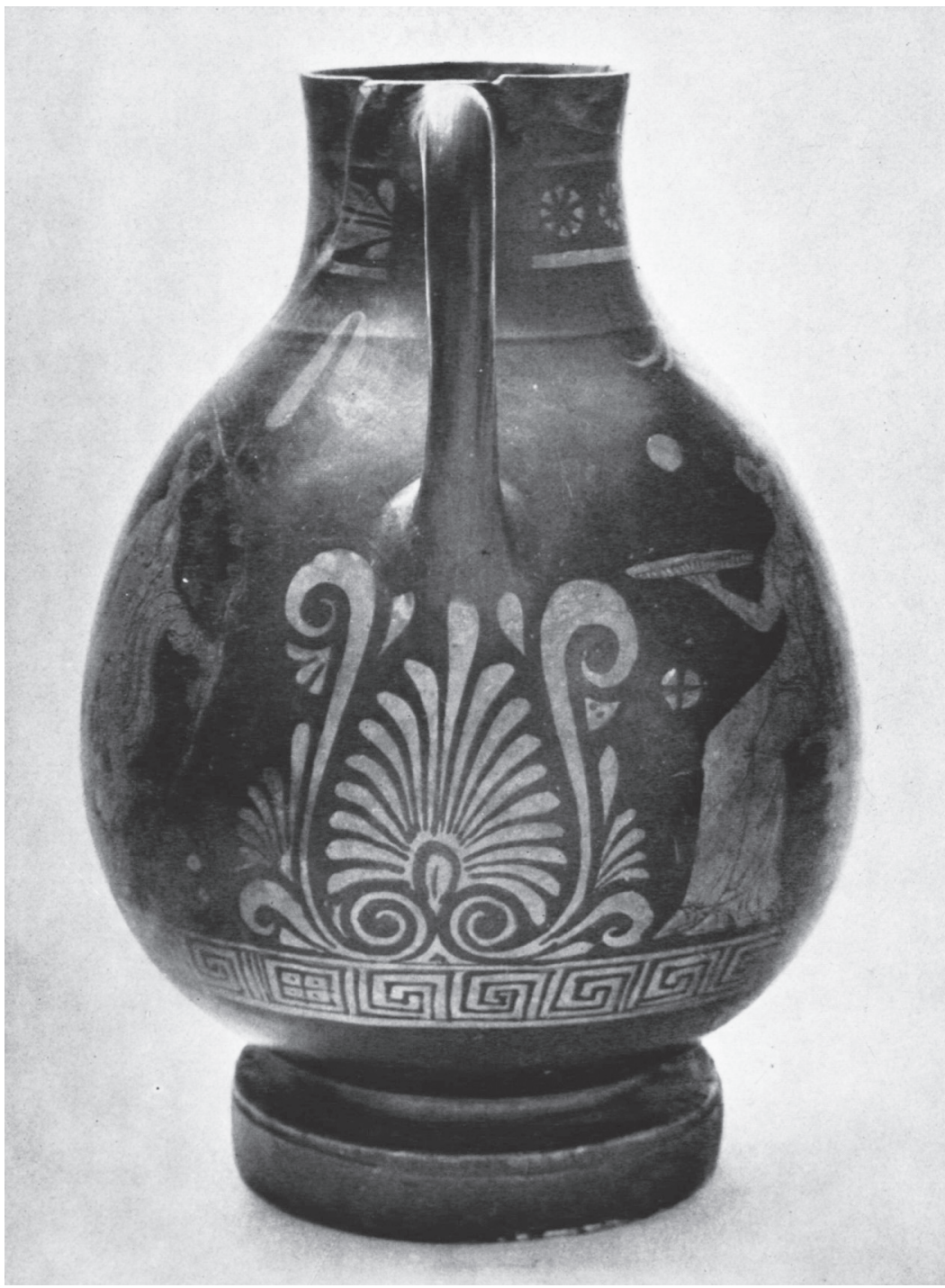




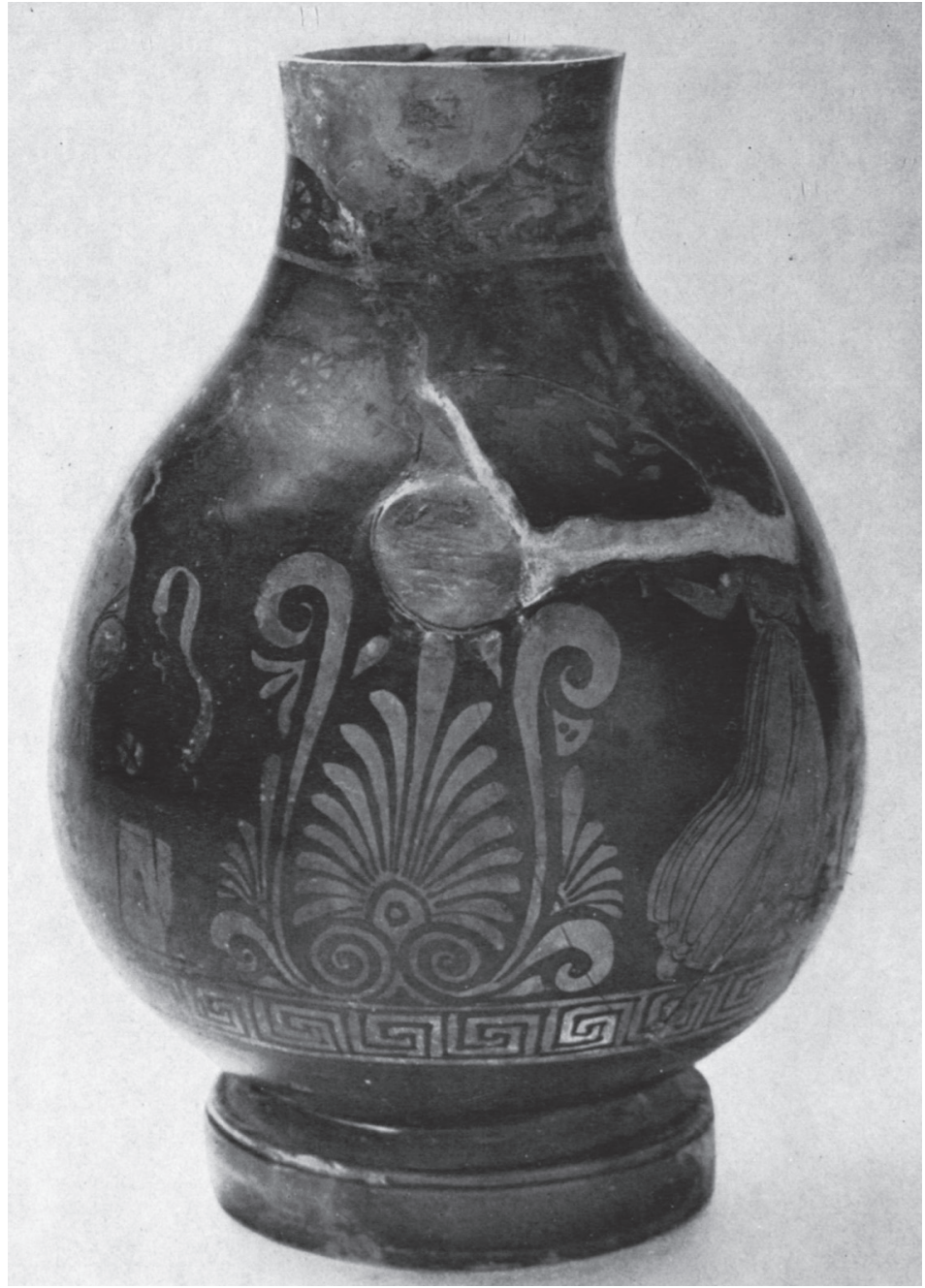




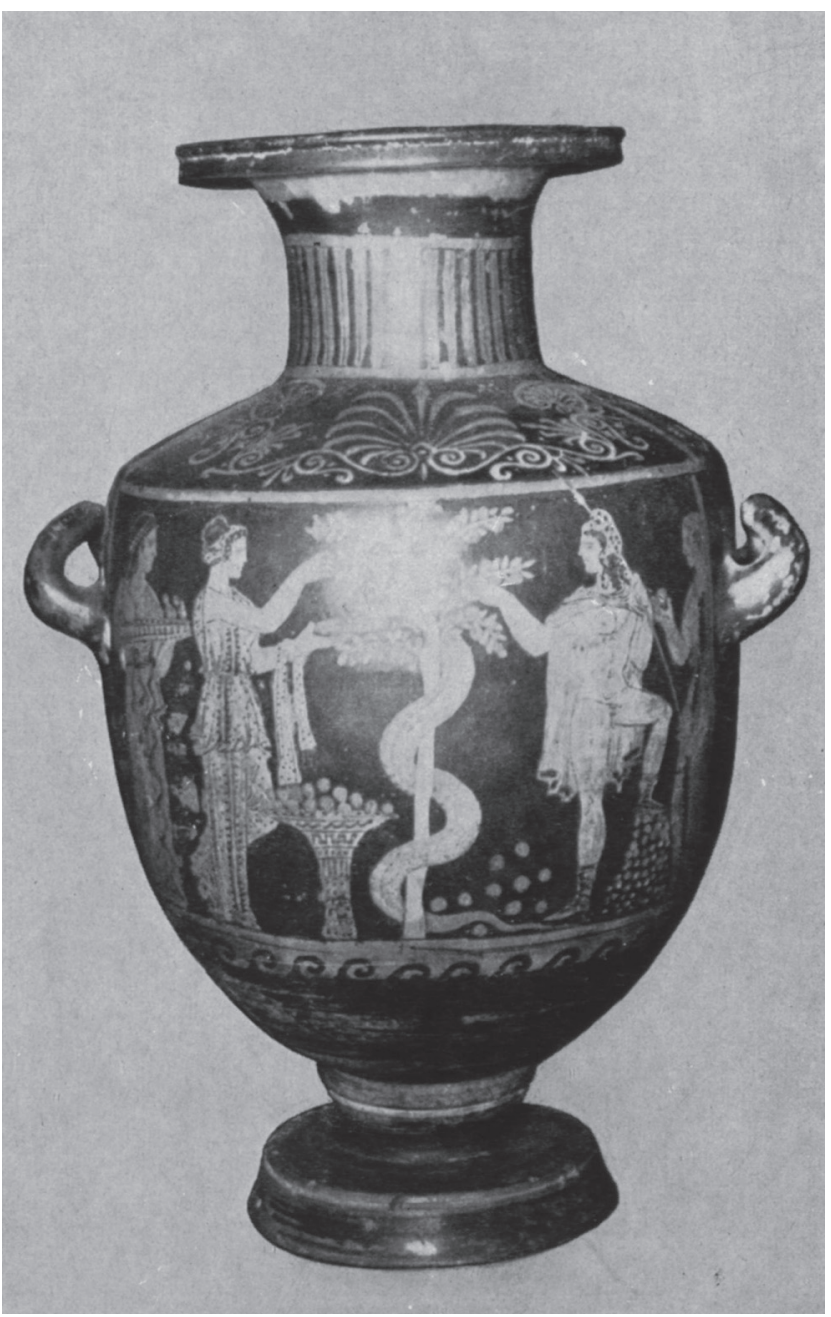




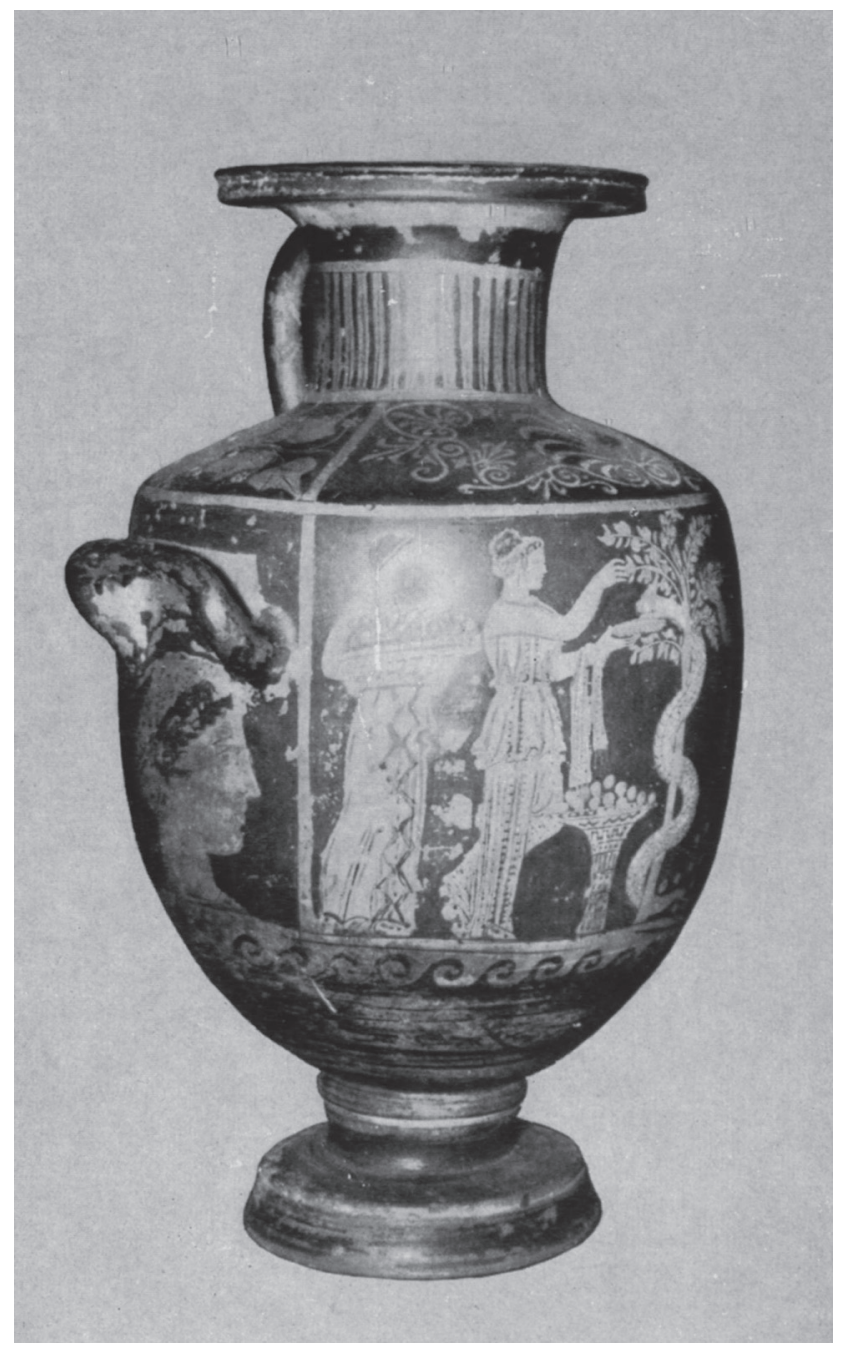


LVI

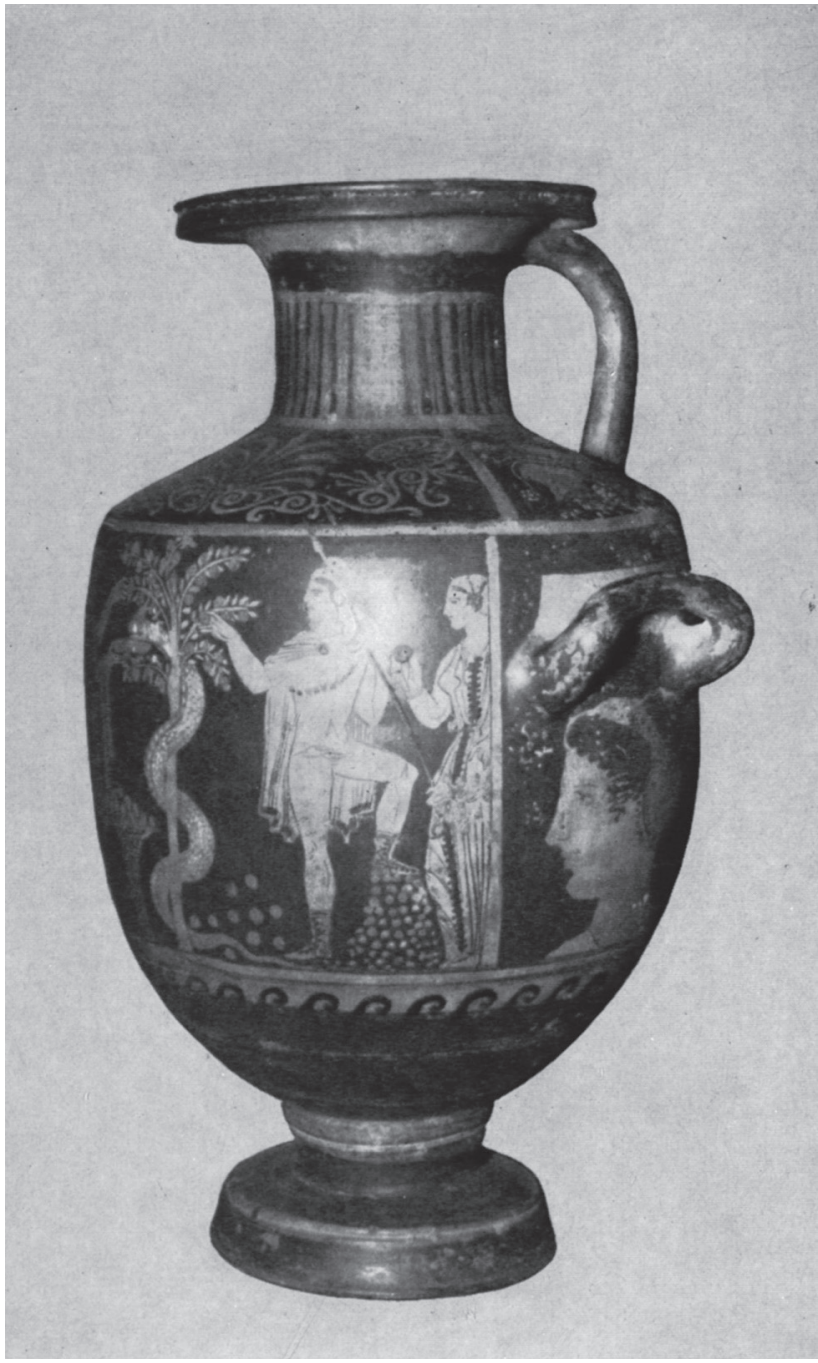




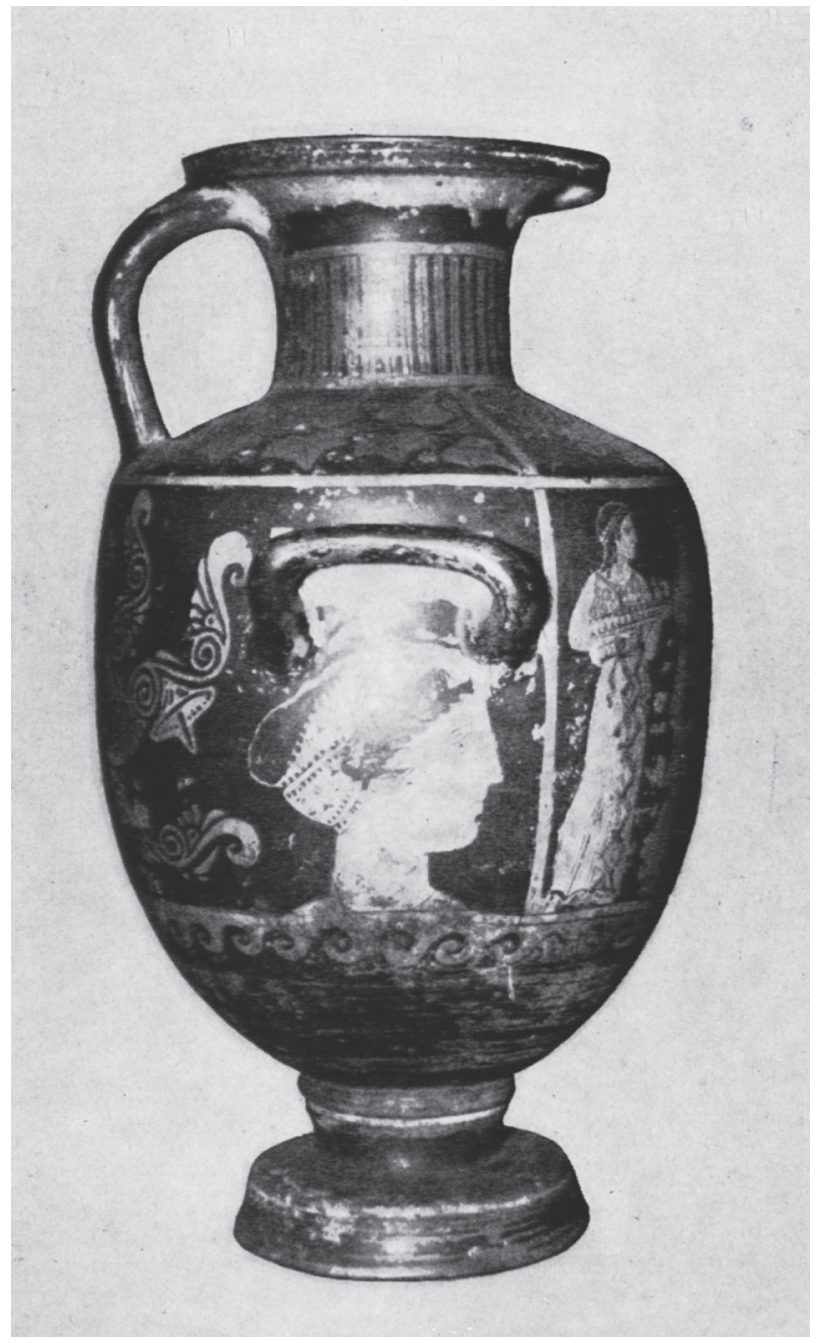


LVIII

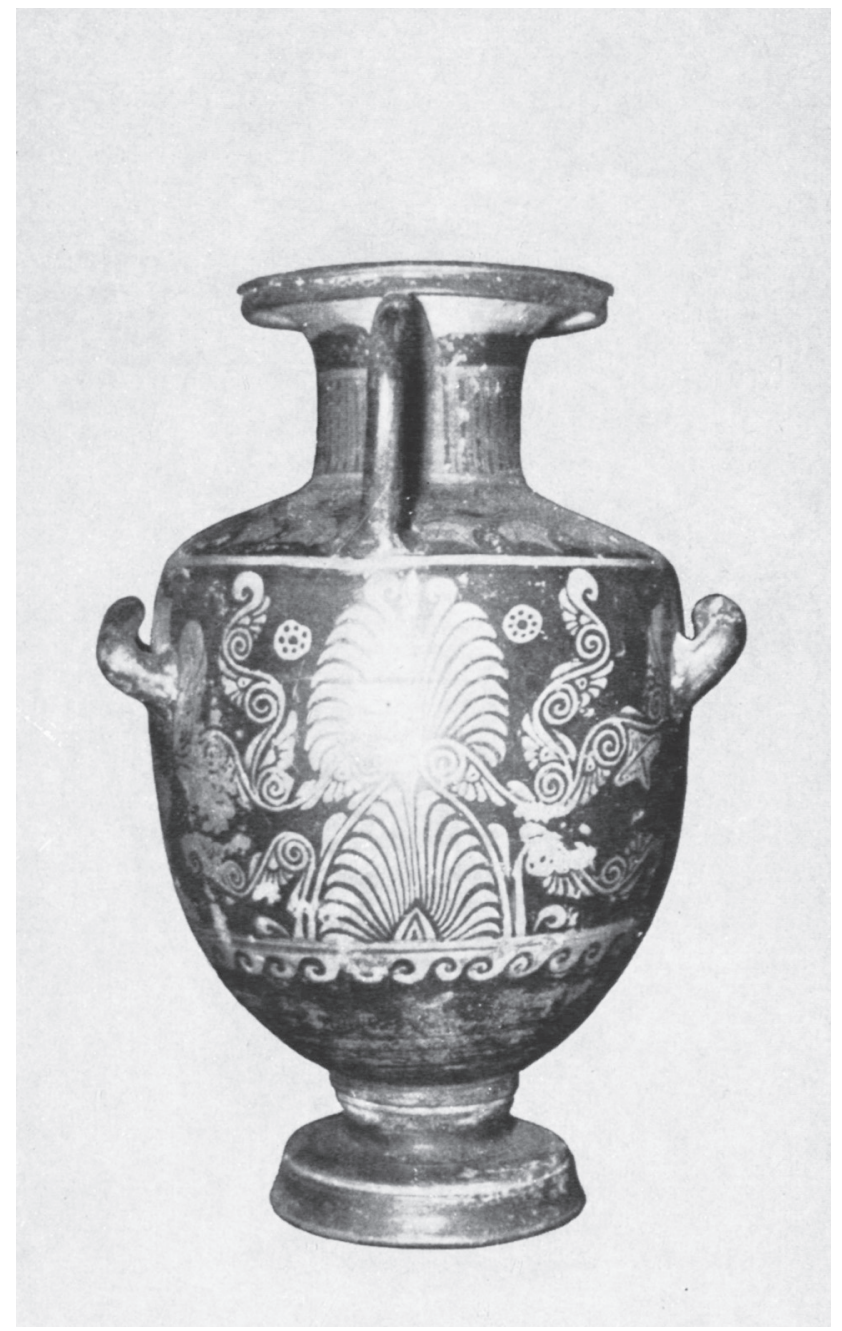




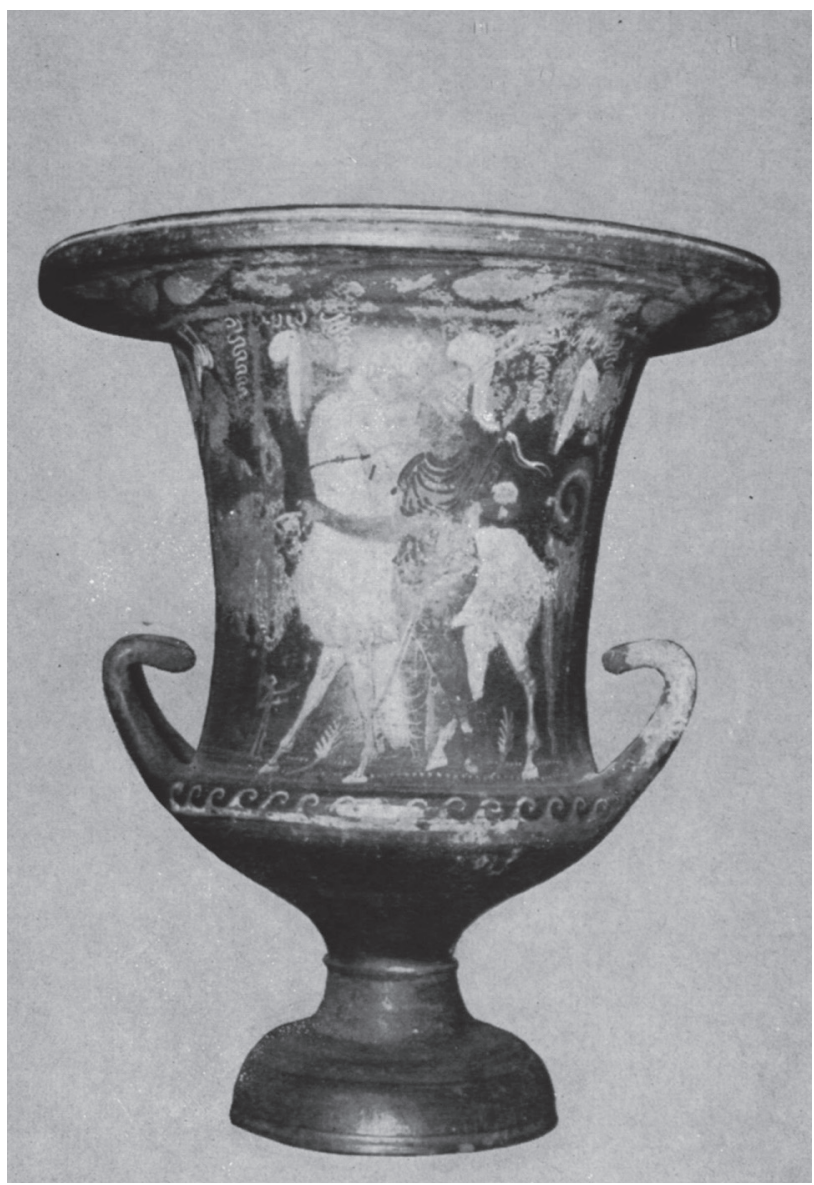


LX

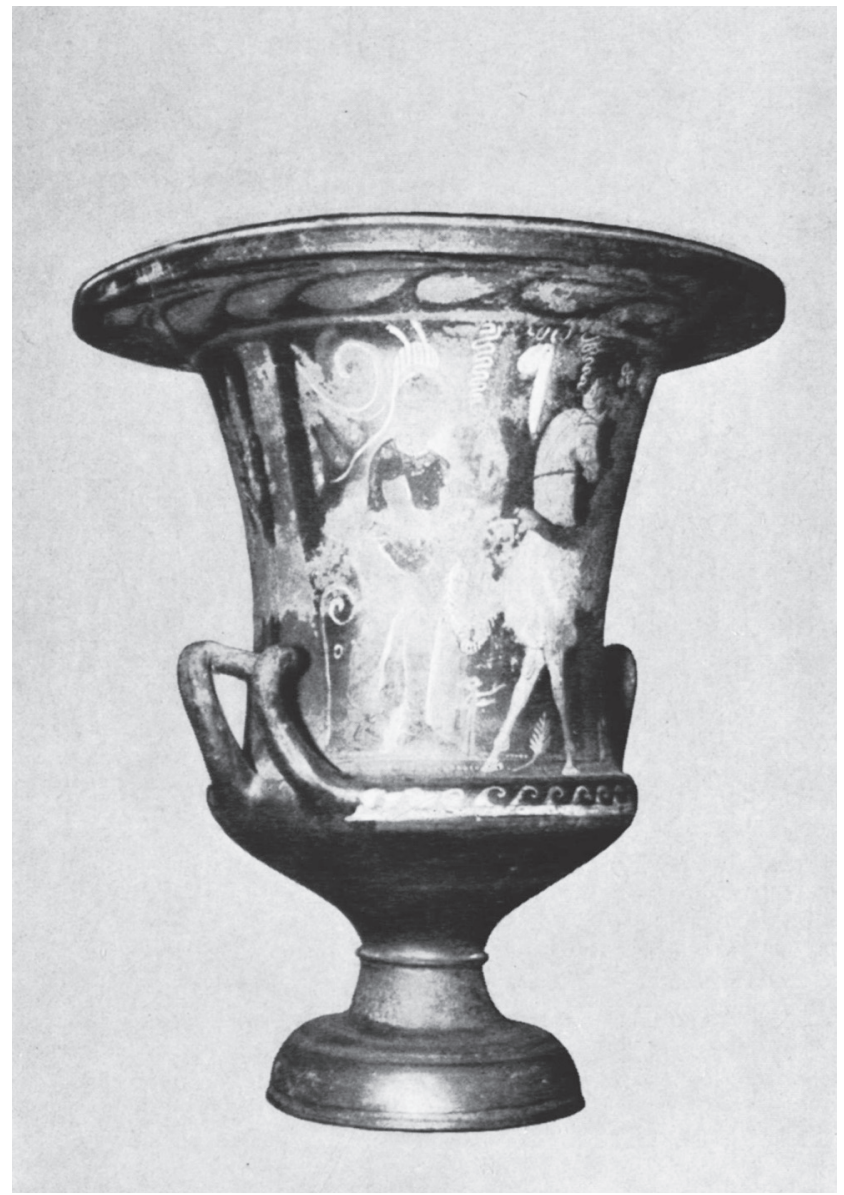




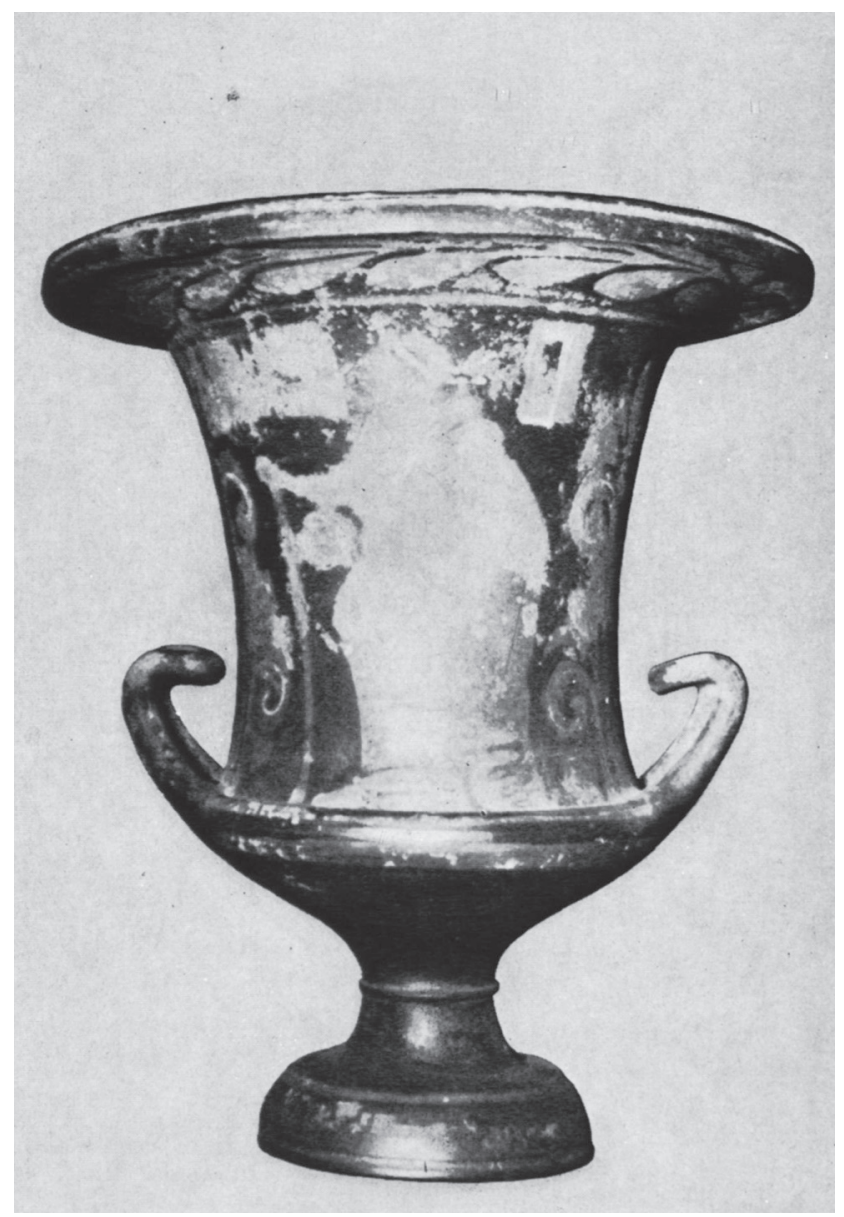


LXII

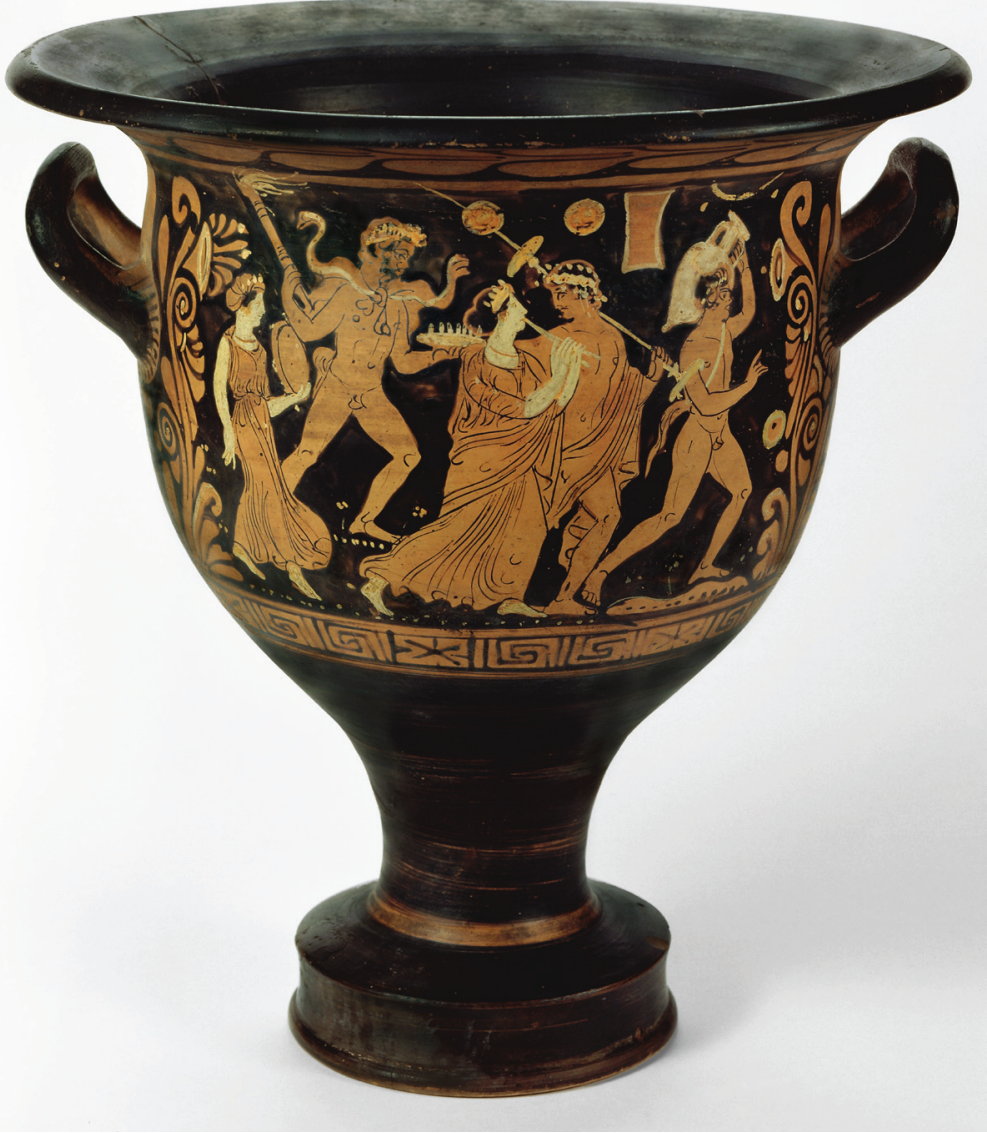


LXIII

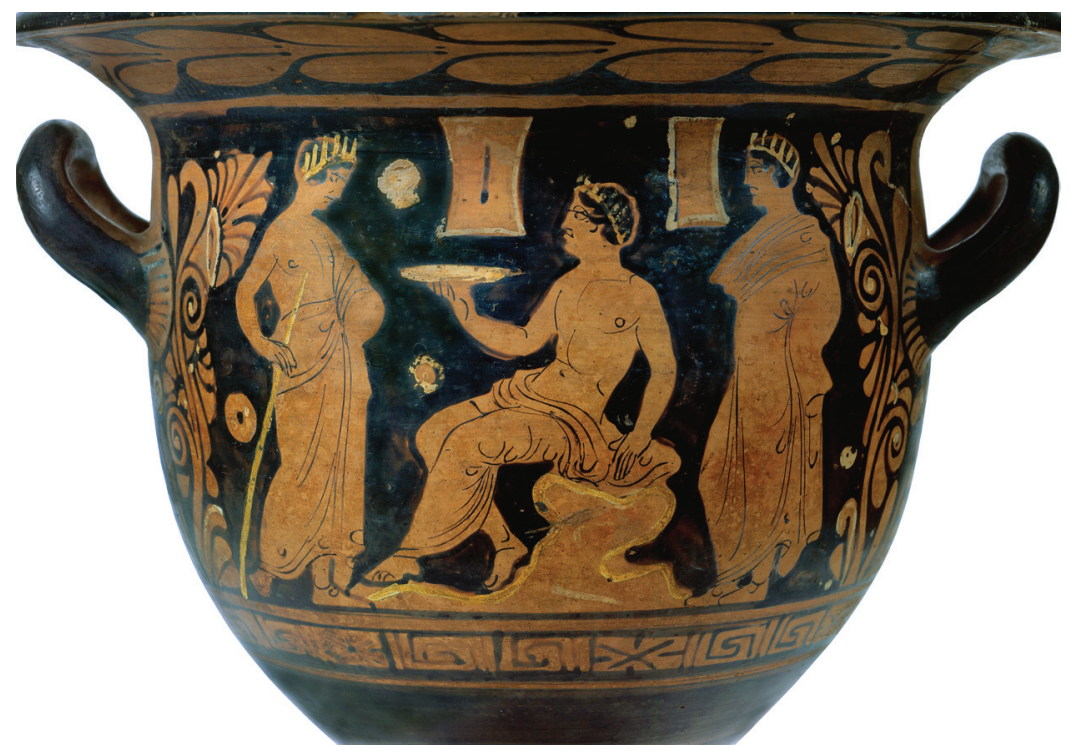


LXIV

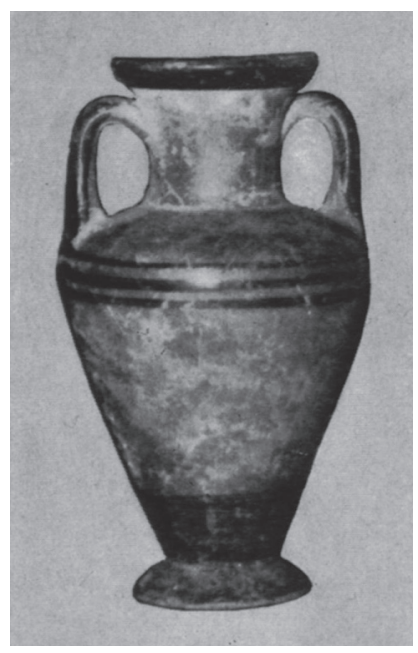




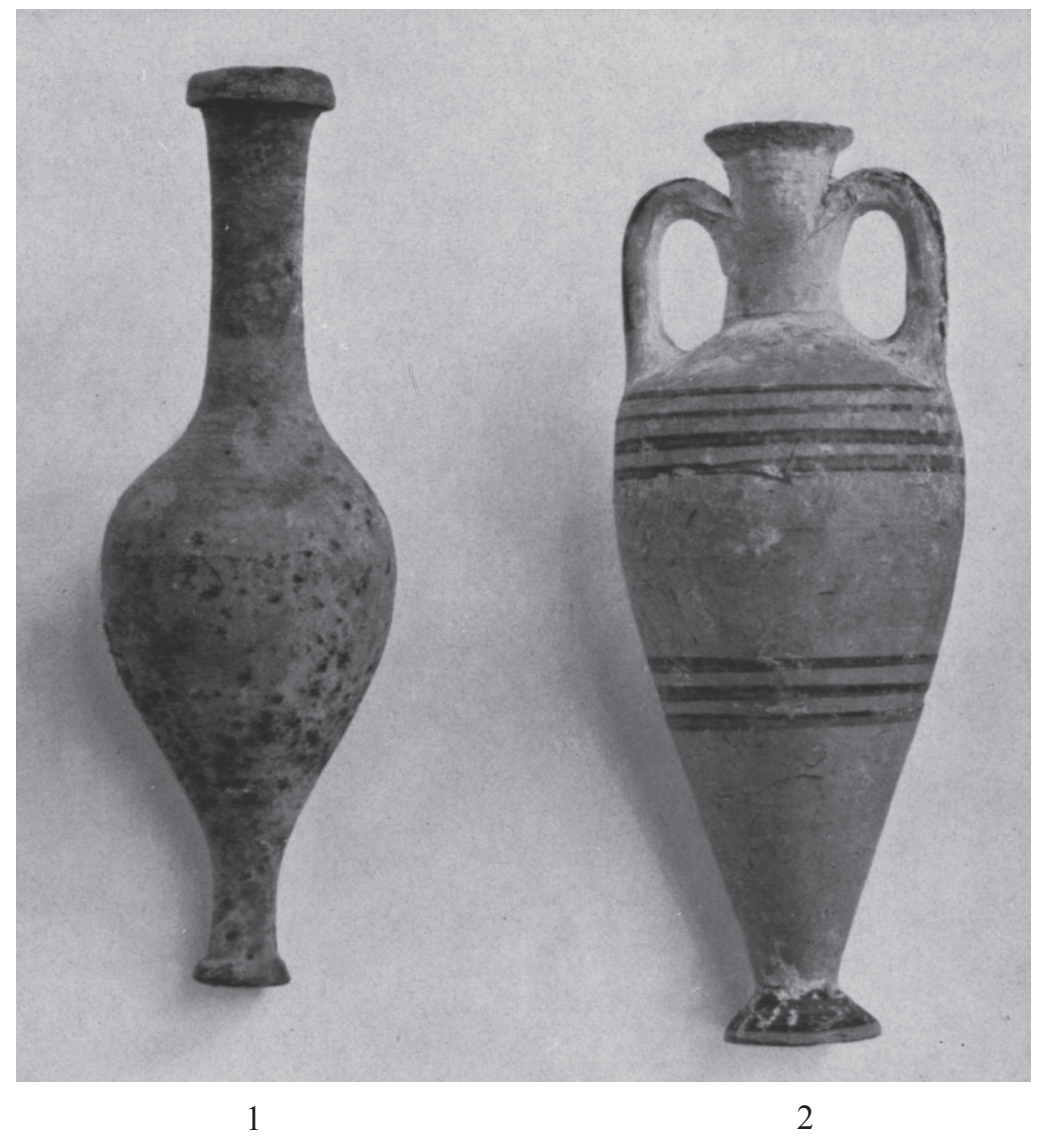


LXVI
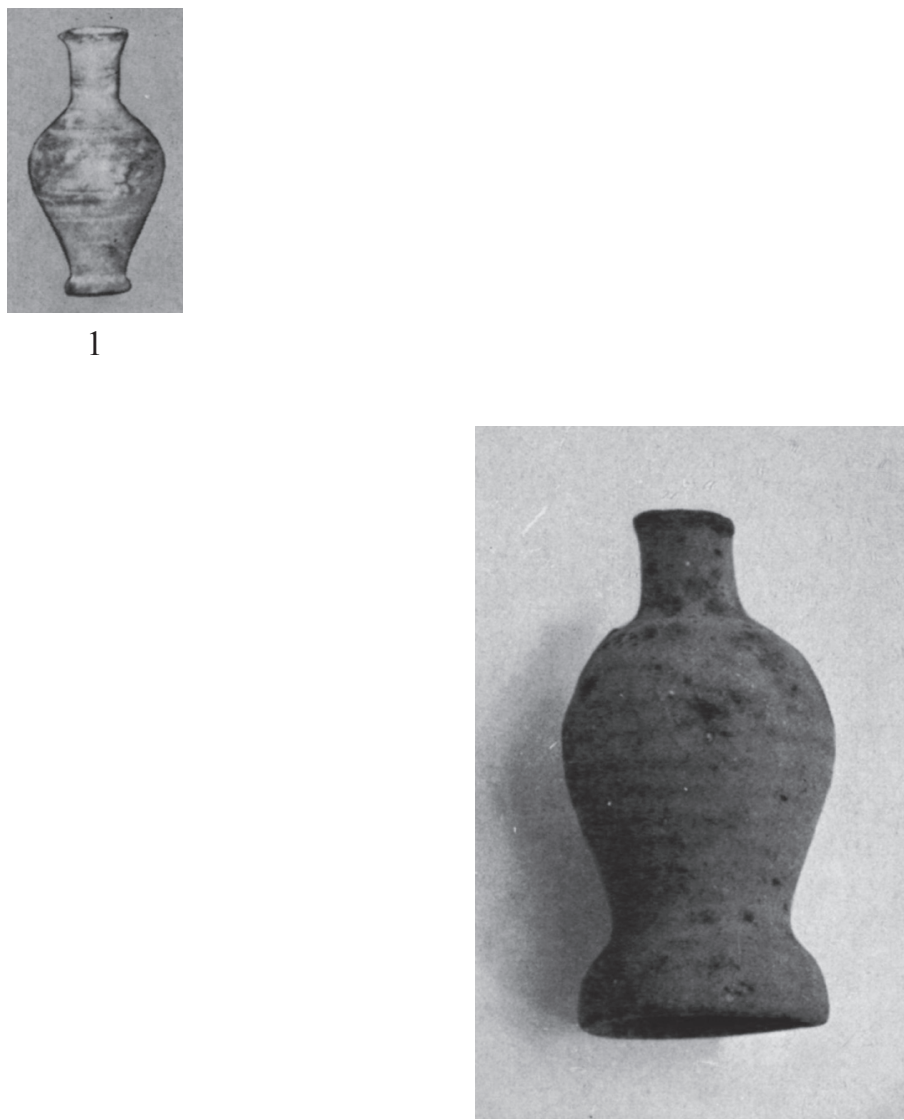

2 
